توظيف الخداع البصرى النسجى كتقنية عصرية

لإثراء الأزياء النسائية الأئية

سماءوأحمد عبدالحميدأحمد

باحثة ماجستير ملابس ونسيج قسم الإقتصاد المنزلي

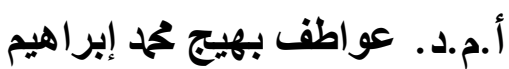

أستاذ الملابس و النسيج المساعد قسم الإقتصاد المنزلي

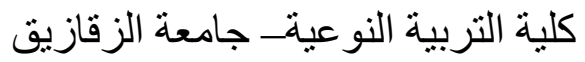

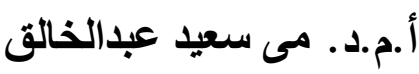

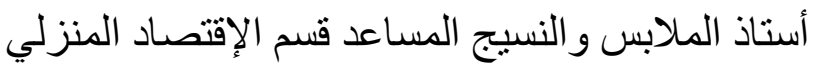

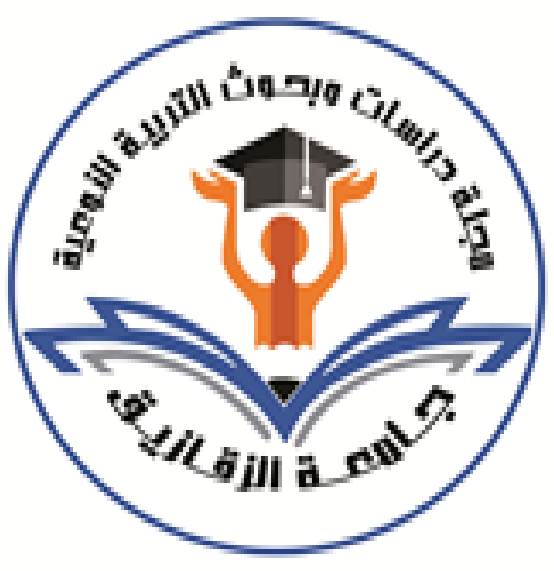

كلية التربية النوعية- جامعة الزقازيق الاقهيق

المجلة العلمية المحكمة لدراسات وبحوث التربية النوعية

المجلد الثامن- العدد الأول- مسلسل العدد (15)- يناير 2022- الجزء الأول

رقم الإيداع بدار الكتب 24274 لسنة 2016

ISSN-Print: $2356-8690$ ISSN-Online: $2356-8690$

https://jsezu.journals.ekb.eg موقع المجلة عبر بنك المعرفة المصري JSROSE@foe.zu.edu.eg

E-mail البريد الإلكتروني للمجلة 


\section{توظيف الخداع البصرى النسجى كتقنية عصرية لإثراء الأزياء النسائية}

إعداد

\section{سماءأحمد عبدالحميدأحمد}

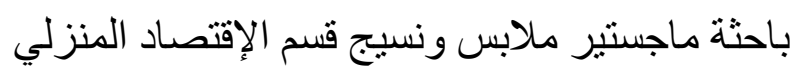

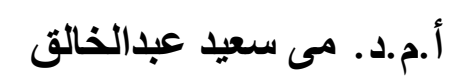

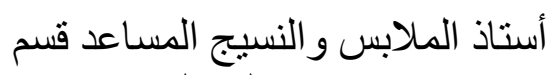

الإقتصاد المنزلي الكياع

كلية التربية النوعية- جامعة الزقازيق

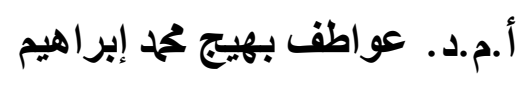

أستاذ الملابس و النسيج المساعد قسم الإقتصاد المنزلي الئياع

كلية التربية النوعية- جامعة الزقازيق

ملخص البحث: يهدف البحث الحالى إلى استحداث مدخل جديد لفن الخداع البصرى يكون مصدره النسيج اليدوى، وتوظيفه كتقنية عصرية لإثراء القيم الجمالية والوظيفية للأزياء النسائية وتم تصميم وتنفيذ ثلاث عينات من النسيج اليدوى ثلاثى الأبعاد بإستخدام الشرائط ك (سداء،

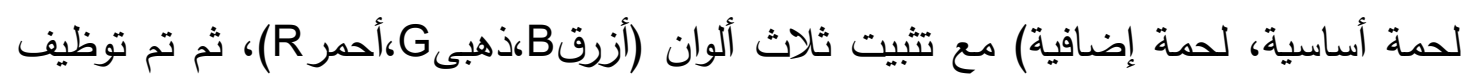
الأقششة المنفذة على خمس أنواع مختلفة ومتتوعة من الأزياء النسائية والحصول على (10) فكرة تصميمية باستخدام برنامج الفوتوشوب، ثم تقييمها من خلال آراء المحكمين باستخدام استمارات

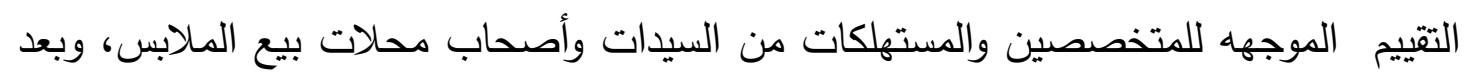
تقييم التصميمات المقترحة للأزياء النسائية وتسجيل البيانات ومعالجتها إحصائياً توصل البحث إلي أن أفضل النتائج جاءت لعينة النسيج اليدوى المنفذ رقم (1) "نسيج منتظم بإستخدام الدمج بين شرائط الأورجانزا والستان والتريكو" ونجاح توظيفها على كل من تصميم الجاكيت البليزر رقم (11) بمعامل جودة 90.01\% وتصميم العباءة الخارجية رقم (0 (1) بمعامل جودة 90\% وذلكي وفقاً لمجموع آراء المتخصصين والمستهلكات وأصحاب محلات بيع الملابس، كما ثبت نجاح توظيف الخداع البصرى النسجى كثقنية عصرية لإثراء التصميمات المتترحة للأزياء النسائية فى ضوء آراء المحكمين مما يساهم فى إتاحة مصدر تتنى وتطبيقى جديد لإثراء الملابس الخارجية للنساء وإبراز جمالياتها، وفى النهاية قدم البحث مجموعة من التوصيات والمقترحات ببحوث مستقبلية لإمكانية تطوير مجال تصميم المنسوجات والملابس لزيادة القيمة الجمالية والتسويقية للمنتج الملبسى المصرى، وإبراز قيمة العمل والفن اليدوى النسجى وتأثيراته المختلفة واعتبارها كمدخل للمشروعات الصغيرة لتتمية اقتصاديات الأسرة والمجتمع. الكلمات المفتاحية: الخداع البصرى، النسيج اليدوى، تقنية، عصرية، الأزياء النسائية. 


\begin{abstract}
:
The current research aims to develop a new approach to art of optical illusion that comes from hand weaving, and employs it as a modern technique to enrich aesthetic and functional values of women's fashion. 3 samples of hand made 3D fabric were designed and implemented using strips as (warp, basic weft, additional weft) with 3 colors installed. (Blue B, Gold G, Red R), then the fabrics implemented on 5 different types of women's fashion were employed and (15) design ideas were obtained using Photoshop, then evaluated through the opinions of the arbitrators using evaluation forms directed to specialists, women consumers and owners of clothing stores. After evaluating the proposed designs for women's fashion, recording data and processing it statistically, research concluded that the best results came for the executed manual fabric sample No. (1) "regular fabric using the combination of organza, satin and knitting strips", the success of its employment on each of the design of the blazer jacket No. (11) with a quality factor $95.51 \%$, the design of the outer gown No. (15) with a quality factor of $95 \%$, according to the total opinions of specialists, consumers, and owners of clothing stores. It also proved the success of employing textile optical illusion as a modern technique to enrich the proposed designs for women's fashion in the light of the arbitrators' opinions, which contributes to providing a new technical and applied source to enrich women's outerwear and highlight its aesthetics. The aesthetic and marketing value of the Egyptian clothing product, highlighting the value of the work and the hand-woven art and its various effects, and considering it as an entry point for small projects to develop the economies of the family and society.
\end{abstract}

Key words: Optical Illusions, Handmade Weaving, Technology, Fashion, Women's Fashion.

المقدمة والدارسات السابقة: Introduction and previous studies

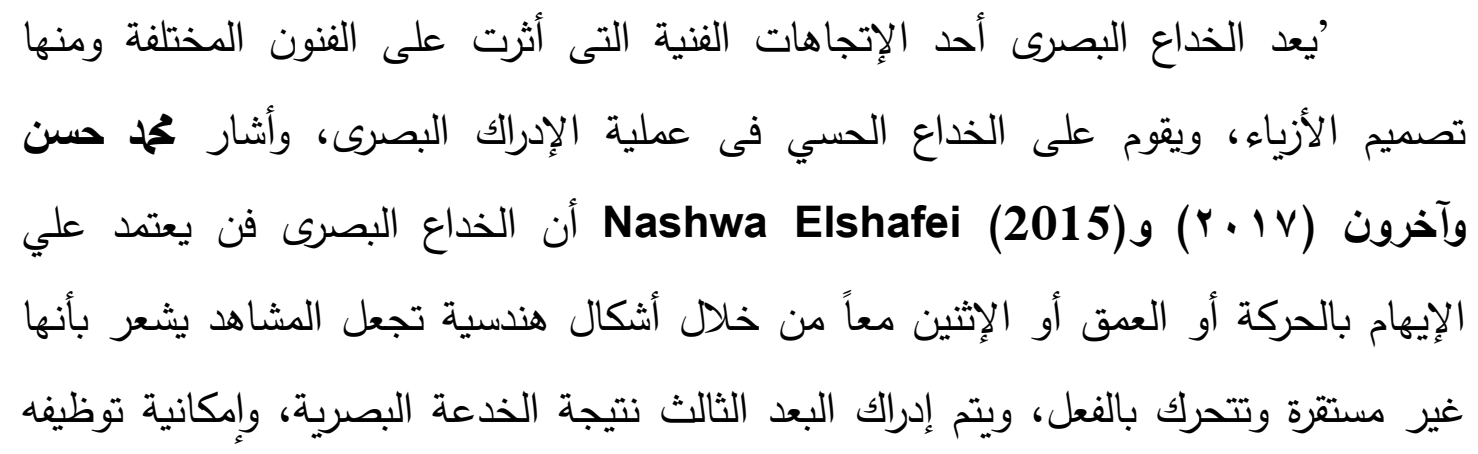


لمعالجة بعض العيوب الجسمية، كما أن ملابس الخداع البصري تؤدي إلى إدراك شكل الجسم

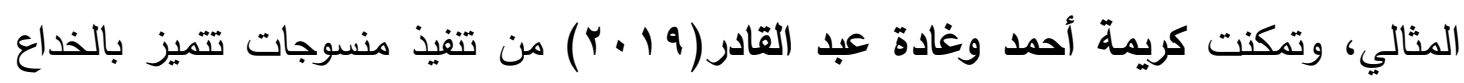
البصرى وتوظيفها فى إثراء القيم الجمالية لحقائب السيدات، وقامت نجلاء طعيمة وغادة

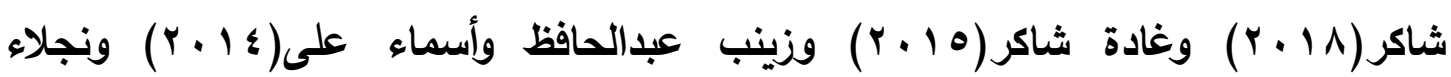

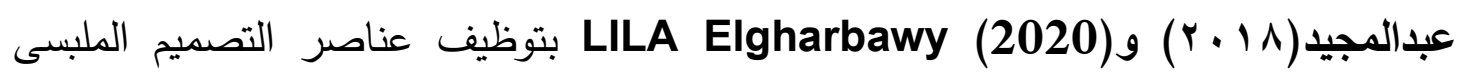
وفنون الخداع البصرى لإخفاء العيوب الجسمية بإستحداث تصميمات زخرفية لإخفاء تلك العيوب وتحقيق الجوانب الوظيفية والجمالية، وقامت صافيناز سمير وعواطف بهيج(1 ا + ب) وهبه

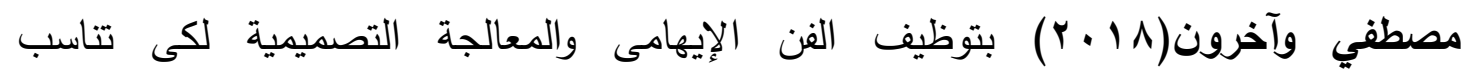
التصميمات والملابس أنماط الجسم المختلفة، وحققت الأزياء المقترحة القيم الوظيفية والابتكارية والجمالية والتسويقية ومواكبتها للموضة وفقاً لآراء المتخصصين والمستهلكين، كما قام فيروز أبوالفتوح وآخرون(9 ( ب ب) بتوظيف الخداع البصرى فى تصميم أقمشة تريكو اللحمة ثلاثية الأبعاد لمعالجة بعض العيوب الجسمية للسيدات،

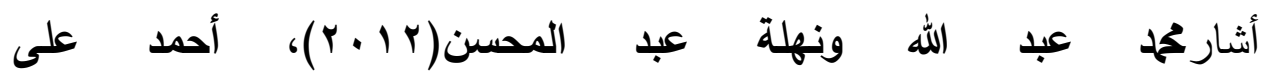

وآخرون(Y Grosicki Z J(2014) أن التقنية لها دورهام فى تطوير النسيج اليدوى نتيجة لنطور الخامات النسجية الحديثة، فكل تقنية يتعرف عليها النساج ويقتيها وينفذها على النول تضيف إلي خبراته امكانيات تثكيلية ورغبة فى البحث عن تقنية جديدة تضيف قيم جمالية جديدة، وإن استخدام أكثر من تقنية وتركيب نسجى فى المنسوج الواحد يحقق تأثيرات جمالية

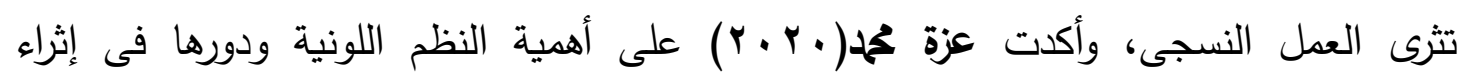
\& Bilisik, K (2016) \& Karaduman N K(2013) تصميمات النسيج، وتمكن Zhenzhen Quan, Tsu Wei Chou (2019) الأبعاد، توصلت نرمين حمدى وعواطف بهيج(1 (1) من إعداد برنامج تدريبي تكنولوجى يتيح إمكانية تصميم وتتفيذ أقشة منسوجة يدوياً ذات بعد ثالث بإستخدام الشرائط المختلفة والحصول علي تأثيرات نسجية مبتكرة وتوظيفها في مجالات الملابس ومكملاتها والمفروشات، وإستفادت لتهني وسام مصطفى وأميمه رووف(10 + r) من الإمكانات التشكيلية للتراكيب النسجية فى رفع القيم

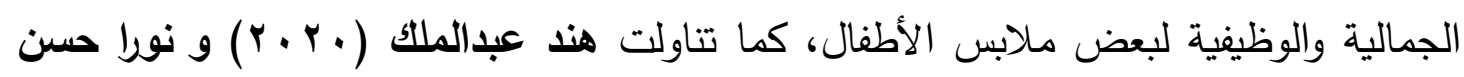

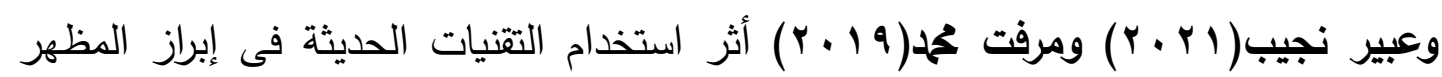


الجمالي لسطح وملمس النسيج والقماش وامكانته التشكيليه لإثراء الملابس والأزياء والإستفادة منها كنموذج للمشروعات الصغيرة، وتمكنت عواطف بهيج وعبدالله عبدالمنعم(ا ب r)

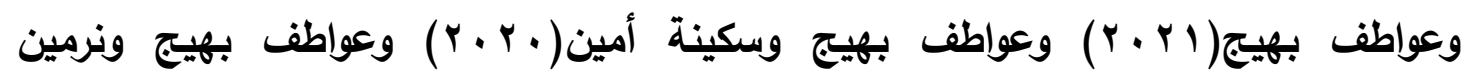
حدى(1 ا • Y) من استحداث رؤى تطبيقية معاصرة لتقنيات وأساليب مبتكرة وخامات غير نمطية لتصميم المنسوجات والأقمشة فى ضوء الإتجاهات الحديثة للنسيج اليدوى متعدد المحاور والأبعاد المختلفة (7D, 3D) وتوظيف امكاناتها التشكيلية وتأثيراتها المختلفة لإثراء بعض المنسوجات والمفروشات والأزياء وملابس السيدات ومكملاتها. وأوضحت رحاب رجب(ع ا • r) أن تصميم الأزياء يعتبردن: الفنون التطبيقية المتخصصة لتصميم الملابس وجزء من السلوك الإنساني والذى يسعى دائماً لإشباع حاجاته، ويتسم بالتجديد والتتوع والإبهار، وهو الكيان المبتكر والمتجدد في خطوطه ومساحاته اللونيه وخاماته المتتوعة وهو اللغة التي تشكلها مجموعة عناصر في تكوين موحد (الخط والشكل واللون والنسيج)، وتعدّ هذه المتغيرات أساس لتعبيره، وتتأثر بالأسس التصميمية لتعطي السيطرة والتكامل والتوازن والإيقاع والنسبة، وتتنوع مجالات وطرق وأساليب تصميم الأزياء وتختلف باختلاف السوق المستهدف وتضم الأزياء الراقية والملابس الجاهزة، وأشارت كفاية سليمان

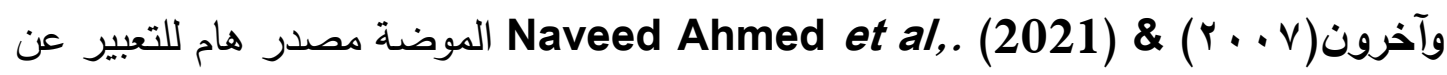
هوية المجتمع، حيث يتم الاستفادة من إتجاهات الموضة فى دراسة إسترتيجية السوق والدوافع الملبسية وما يجذب المستهلك فى الوقت الحالى حيث تثير إلى إتجاه تحرك الموضة، ويقوم المصمح بمتابعة اتجاهات الموضة المحلية والعالمية، ليكون ملم بكل ما هو جديد في مجال عمله، وأكدت زينب أحمد وعبير نجيب (. . . . على تعدد إحتياجات المرأة من الملابس الخارجية لخروجها إلى العمل، وحاجتها للتغيير المستمر للظهور بشكل لائق جذاب ومميز. وتعتبر الملابس الخارجية جزء مكمل للشخصيه، ولها التأثير النفسى فتشعر بالتتوع والتجديد والجاذبية، وتتميز الملابس الخارجية للسيدات بشكل خاص بالفخامة والبساطة فى خطوطها وطبيعة الوانها، فيستدعى ذلك الإتجاه نحو تصميم ملابس عصرية واقتصادية، وهو ما أشارت إليه غادة شاكر (10 • r) بتوجه المرأة نحو اختيار ملابسها لجذب إنتباه الآخرين والتزين وتحقيق الذات والتكيف مع الآخرين والاحتشام والموضة والحماية وتحقيق الأناقة بالتركيز على

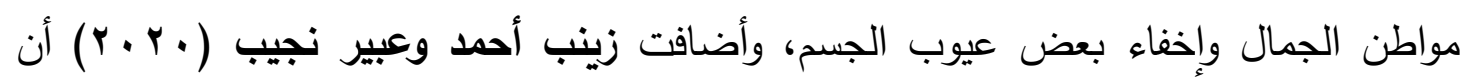
المجلد الثامن- العدد الأول-مسلسل العدد (15)- يناير 2022- الجزء الأول 
تصميم الملابس الخارجية للسيدات يحتاج دائما إلى الإبتكار المتجدد في خطوطه المختلفة، لذلك يجب على المصمم أن يترجم ما لديه من مساحات لونية وخامات وخطوط مختلفة لإبتكار وإستحداث تصميمات تجمع بين الوظيفة والجمال. كما تعد الملابس الخارجية من أهم أنواع الملابس التى تهتم المرآة بإقتنائها لتحافظ على هيئتها الخارجية وقوامها جمالياً بما لا يؤثر على

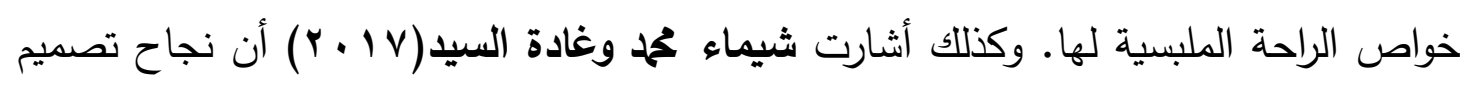
الملابس يعتمد على مدى ملاعمته للغرض الوظيفي وعلى مدى التكامل بين الجانب الوظيفي والجانب الجمالى، الأمر الذى يفرض على المتخصصين ضرورة التتوع في تقنيات الإنتاج للمساعدة على فتح أسواق جديدة للمنتج الملبسي، واكدت على أن الملابس ذات التصميم المناسب والقماش الجيد تمنح مرتديها الثقة وتعمل على إخفاء عيوب الجسم وتحقيق الخواص الوظيفية للملبس، وتمكنت دعاء عبدالمجيد (9 ( • ( ) من الاستفادة من المكملات المنفصلة من الكروشية لتجديد وإعادة إستخدام ملابس السهرة لتناسب اتجاهات المرأة العاملة، وأكدت سناء عحم (9 ( ب ) أهمية الإستفادة من مهارات التفكير الإبداعي لاستحداث صياغات تشكيلية لمكملات الملابس لخدمة الصناعات الصغيرة. التعليق العام على الدراسات السابقة: بإستعراض ما سبق من الدراسات المرتبطة بموضوع البحث فى تتاولها لمفاهيم الخداع البصرى والتقنيات المختلفة للنسيج والتصميم والموضة والملابس الخارجية والإحتياجات الملبسية للمرأة من الناحية الجمالية والوظيفية، وأكدت معظمها على أهمية دور التصميم والإتجاهات والتقنيات المختلفة للإرتقاء بمستوى جودة التصميم وامكانية تعظيم الاستفاده منه لتلبية احتياجات المرأة، إلا أنه توجد ندرة في تطرق بعض الدراسات نحو التقنيات العصرية للخداع البصرى النسجى كمدخل جديد لمجال التطوير والتحديث والإبتكار فى تقنيات وأساليب النسيج اليدوى للحصول على منتج ذو قيمة جمالية ووظيفية يمكن الإستفادة منه فى إثراء مجالات الملابس والازياء النسائية.

\section{مشكلة البحث: Statement of the Problem}

نظراً للتوجهات المعاصرة نحو الحداثة والإبتكار فى استخدام تقنيات وأساليب تؤدى إلي منتج متميز له سمات وخواص يمكن توظيفها لإحداث طفرة فى تطوير وتجديد مجالات الملابس والنسيج، ومن خلال نتائج الدراسات السابقة ظهرت مشكلة إنتشار الأنماط الملبسية النمطية للسيدات وخاصة مع بعض المقاسات والأجسام النسائية التى بها بعض العيوب الجسمية، والتى 
يترتب عليها إصابة المرأة بالرتابة والإحباط عند اختيارها للملابس المناسبة والملائمة لطبيعة جسمها، وذلك لإنحصار معظم التصميمات والموديلات فى الشكل الكلاسيكى الواسع الفضفاض كمحاولة لإخفاء العيوب الجسمية، ومن هنا ظهر عدم الملاعمة للملابس مع المقاييس والعيوب الجسمية للمرأة؛ فتتحنى برغباتها إلي الإختيار الإضرارى لتصميمات وموديلات نمطية خالية من اللمسات الفنية الجذابة مسطحة المعالم بمقاسات قد تكون أكبر حتى تستطيع إجراء عمليات الضبط والتعديل لتصل إلي الحد الأدنى من الملائمة الشكلية وتفتقد الكثير من الملاعمة النفسية والتى تؤثر سلبياً على ثقتها بالنفس، ومن هنا اتجهت فكرة البحث الحالى نحو العمل على تحقيق معادلة الملاءمة والجودة والقيمة الجمالية والوظيفية لتحقيق الجاذبية والتميز والتفرد لأزياء خارجية نسائية عصرية ثرية بالنسيج اليدوى الإيهامى تلبى متطلبات المرأة وتطلعاتها المستقبلية، لذا تم التوجه نحو إجراء البحث الحالي تحت عنوان (توظيف الخداع البصرى النسجى كتقنية عصرية لإثراء الأزياء النسائية).

\section{تتمثل مشكلة البحث في التساؤلات الأتية:}

- ما تأثير إختلاف خامة النسيج المنفذ علي ملاعمة توظيف الخداع البصرى النسجى على التصميمات المقترحة للأزياء النسائية.

- ما تأثير الدمج بين خامات النسيج المنفذ علي الخداع البصرى النسجى الناتج وقيمة توظيفه على التصميمات المقترحة للأزياء النسائية. - كيف يمكن توظيف الخداع البصرى النسجى لإثراء الأزياء النسائية الوظيفية (تساهم فى إخفاء بعض العيوب الجسمية)؟

- ما تأثير الخداع البصرى النسجى المنفذ على الجوانب الجمالية والوظيفية للأزياء النسائية؟ - ما هي آراء كلاً من المتخصصين والمستهكات وأصحاب محلات بيع الملابس في التصميمات المقترحة كمنتج ملبسى مناسب اقتصادياً ويساهم في إخفاء بعض العيوب الجسمية ويوحى بالخداع البصرى؟

أهداف البحث: Objectives - ابتكار تصميمات نسجية توحى بالخداع البصرى والاستفادة منها فى إثراء الأزياء النسائية العصرية . 
- تقديم تصميمات تلبى حاجات المستهلك من الجوانب الجمالية والوظيفية والإقتصادية وتوحى

$$
\text { بالخداع البصرى. }
$$

- الوصول إلي أنسب نوع خامة مستخدمة للنسيج اليدوى يوحى بالخداع البصرى ويحقق جودة الخواص الجمالية والوظيفية للمنتج النسجى.

- الوصول إلي أنسب أسلوب للدمج بين الخامات تحقق جودة الخواص الجمالية والوظيفية للمنسوج والتصميمات المقترحة للأزياء النسائية. - تقييم المنسوجات المنفذة فى امكانية توظيف الخداع البصرى النسجى لإثراء التصميمات المقترحة للأزياء النسائية من قبل المحكمين (المتخصصين، المستهلكات، أصحاب محلات

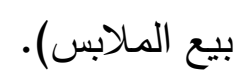

\section{أهمية البحث:Significance}

- توظيف أسلوب الخداع البصرى النسجى لتحقيق قيم جمالية ووظيفية واقتصادية للأزياء النسائية.

- توظيف فن الخداع البصرى النسجى كمصدرا لإثراء الأزياء النسائية العصرية. - تعتبر الدراسة الحالية ضمن الدراسات الأولية التي تهتم بإستحداث مصدر للتقنيات العصرية للخداع البصرى النسجى والاستفادة منه لإخفاء بعض العيوب الجسمية ومسايرة للموضة. - إلقاء الضوء على امكانية الإستفادة من اختلاف الخامات والدمج بينها لتنفيذ منسوجات ثلاثية الأبعاد ذات قيم مختلفة وتوحى بالخداع البصرى النسجى. - فتح أفاق جديدة من الناحية الفنية والتقنية فى مجال المنسوجات اليدوية الأزياء المبتكرة وتشجيع المشروعات الصغيرة.

فروض البحث:Hypothesis

- توجد فروق ذات دلالة إحصائية وفقاً لأراء المتخصصين بين امكانية توظيف الخداع البصرى النسجى على التصميمات المقترحة للأزياء النسائية بالبحث فى تحقيق جوانب التقييم. - توجد فروق ذات دلالة إحصائية وفقاً لأراء المستهلكات بين امكانية توظيف الخداع البصرى النسجى على التصميمات المقترحة للأزياء النسائية بالبحث فى تحقيق بنود التقييم. 
- توجد فروق ذات دلالة إحصائية وفقاً لأراء أصحاب محلات بيع الملابس بين امكانية توظيف الخداع البصرى النسجى على التصميمات المقترحة للأزياء النسائية فى تحقيق بنود التيقييم. - توجد علاقة إرتباطية دالة إحصائياً بين ترتيب (المتخصصين، المستهلكات، أصحاب محلات بيع الملابس) لامكانية توظيف الخداع البصرى النسجى لإثراء التصميمات المقترحة للأزياء النسائية.

حدود البحث: Delimitations

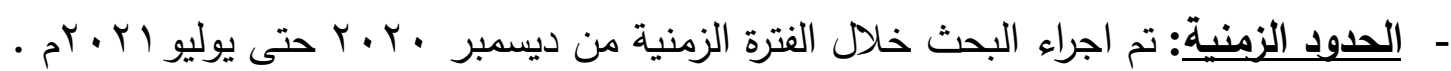
- الحدود البشرية: عينة البحث المستهكات وتشمل (•ء) من السيدات أعمارهن ما بين

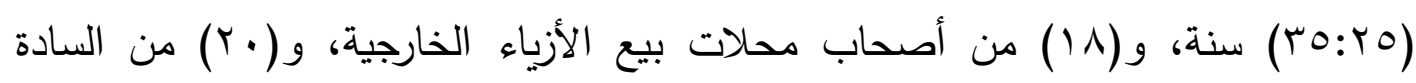
المحكمين المتخصصين فى مجال الملابس والنسيج. - الحدود المكانية: شراء الثرائط المستخدمة تحت البحث (طبقاً للمتغيرات البحثية) من الأسواق المحلية، وتقييم النسيج المنفذ والتصميمات المقترحة للأزياء النسائية من قبل عينة البحث من من البناه

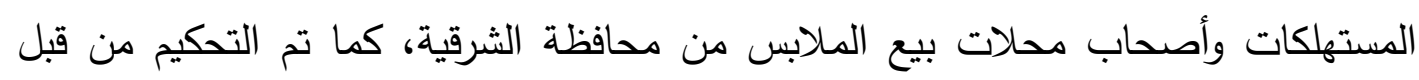
المحكمين المتخصصين في مجالى (الملابس والنسيج، تصميم الأزياء) بكليات (الإقتصاد المنزلى، الفنون التطبيقية، التربية النوعية) بالجامعات المصرية. - الحدود التطبيقية: - تنفيذ عينات النسيج الثلاثى الأبعاد وعددها(ץ)عينات: تم إستخدام(r) أنواع من الشرائط

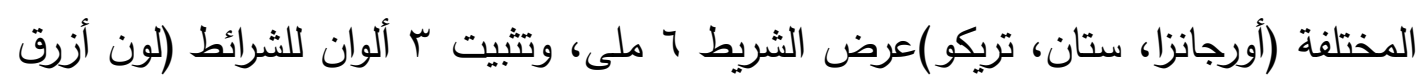

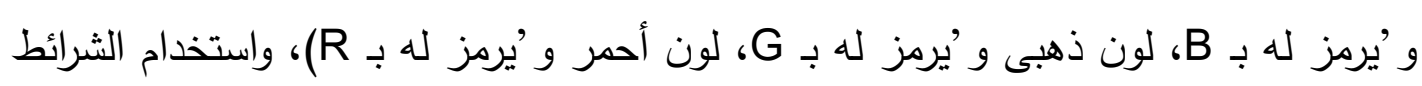

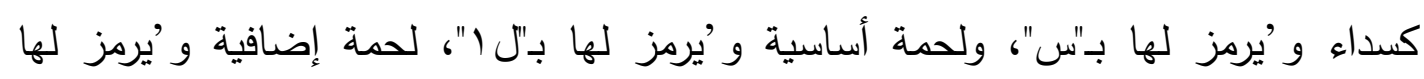

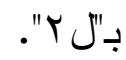
- تصميم عدد (0) تصميمات مقترحة للأزياء النسائية الخارجية: تم استخدام برنامج الفوتوشوب (Photoshop)، وتثمل التصميمات المقترحة (جاكيت قصير بليزر، وبنطلون جينز وهاف بوت وسويت شيرت، وفستان ستان عصرى، وتيشرت شيفون وجونلة ستان، وعباءة خارجية).

المجلد الثامن- العدد الأول- مسلسل العدد (15)- يناير 2022- الجزء الأول 
- توظيف النسيج المنفذ وعرض إمكاناته التثكيلية على الأزياء المقترحة: تم استخدام برنامج الفوتوشوب (Photoshop) والحصول على عدد (10) تصميم مقترح لأزياء السيدات الخارجية تساهم فى إخفاء بعض العيوب الجسمية وتُرتدى فى فترات ومناسبات مختلفة. - تقييم الإمكانات التثكيلية والقيم الجمالية والوظيفية لتوظيف الخداع البصرى النسجى الناتج من النسيج المنفذ على التصميمات المقترحة للأزياء النسائية: من قبل(المتخصصين،

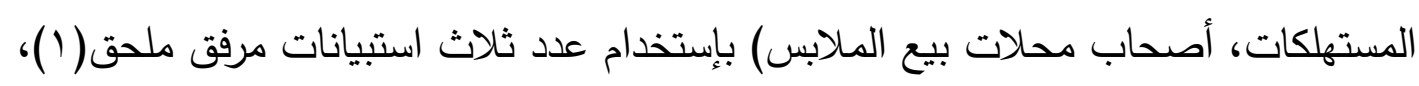

$$
\text { أدوات البحث: }
$$

- الخامات والأدوات: نول خشبى مقاس هلسم'، إبرة إيتامين، خيط صنارة لتثبيت نهايات

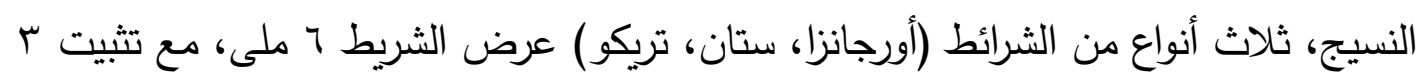

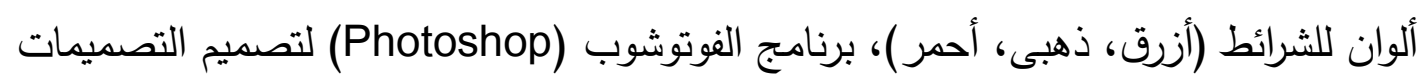
المقترحة للأزياء النسائية وتوظيف العينات المنفذة من النسيج ثلاثى الأبعاد. - اعداد استبيانات التقييم: لإستطلاع رأي كل من (المتخصصين، المستهلكات، أصحاب محلات بيع الملابس) فى الإمكانات التشكيلية والقيم الجمالية والوظيفية لتوظيف النسيج المنفذ على التصميمات المقترحة للأزياء النسائية.

\section{منهج البحث: Methodology}

يتبع البحث المنهج التجريبى والمنهج التحليلي الوصفى لتحقيق الفروض والوصول لأهداف البحث.

\section{المصطلحات العلمية للبحث:Definitions}

- الخداع البصرى: فن يعتمد علي الإيهام بالحركة أو العمق أو الإثثين معاً عن طريق المزاوجة

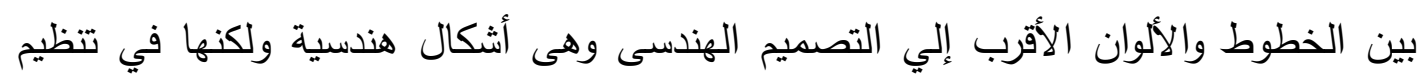
خاص يجعل المشاهد يشعر بأن الأشكال غير مستقرة وتتحرك فعلاً Nashwa Elshafei (2015)، وعرفته الدراسة بأنه الخداع البصرى النتائج من خلال التأثير البصرى الناتج من 
التعاشقات لدحاور النسيج اليدوى والذى يوحى بالثكل ثلاثى الأبعاد (3D)، ويتم توظيف الخداع البصرى النسجى لإثراء الأزياء النسائية جمالياً ووظيفياً.

- النسيج اليدوى: المنسوجات التى يتم نسجها يدوياً بإستخدام التراكيب النسجية الأساسية

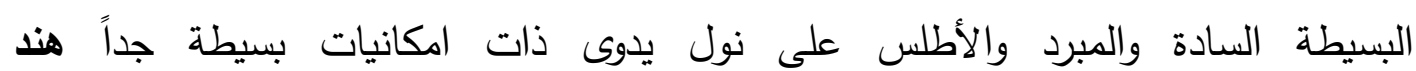
فؤاد(Y V V P ). وعرفته الدراسة بأنه استخدام الشرائط المختلفة كلحمات وسداء واجراء عملية التعشيق لتلك الثرائط باستخدام التراكيبة النسجية المحدة لعمل النسيج اليدوى وذللك باستخدام النول الخشبى. - التقنية: الطرق المستخدمة لإخراج العمل بشكل صحيح بإستخدام الطرق الصناعية الصحيحة، كما أنها مجموعة من المهارات والعمليات التى يمر بها الفرد للوصول إلى منتج

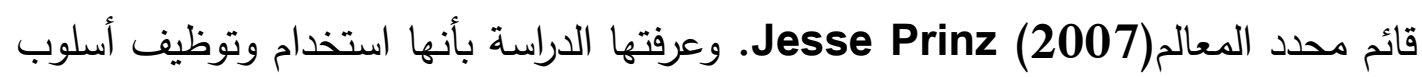
الخداع البصرى النسجى الناتج عن النسيج اليدوى المنفذ بالبحث لإثراء الأزياء النسائية جمالياً ووظيفياً.

- عصرية: معايشة الحاضر بالوجدان والسُّلوك والإفادة من كلّ منجزاته العلميَّة والفكريَّة وتسخيرها لخدمة الإنسان ورقيّه، وتعني الجدة والحداثة (2007) Jesse Prinz، وعرفتها الدراسة علي أنها إكساب التصميمات المقترحة للأزياء الحريمى صفة الجدة والحداثة والمسايرة لخطوط الموضة والعادات والتقاليد المجتمعية. - - تصميم الأزياء: عملية تخطيطية لأسس وعناصر التصميم بهدف تنظيم العلاقات الجمالية بينهم وذللك لإبداع زي مبتكر، بتوظيف العناصر المستخدمة في عملية التصميم لتحقيق

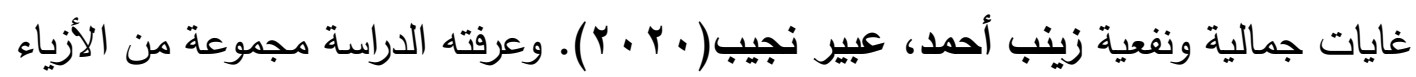
الخارجية تصلح للنساء مثل الفستان والعباءة والبنطلون والجونلة والجاكيت والتى شيرت تم توظيف الخداع البصرى النسجى للنسيج المنفذ فى إثراء جمالياتها وإخفاء بعض العيوب الجسمية للمرأة.

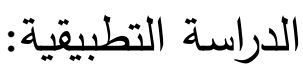
أولاًا- تنفيذ النسيج ثلاثى الأبعاد: 1- قص وتجهيز الثرائط المستخدمة: 
لعمل (T) عينات من نسيج ثلاثى الأبعاد المنتظم والغير منتظم تبعاً للمتغيرات التالية ثلاث شرائط (أورجانزا، ستان، تريكو) عرض الشريط T ملى، مع تثبيت r ألوان للشرائط (لون أزرق و 'يرمز له بـ B، لون ذهبى و يرمز لله بـG، لون أحمر و 'يرمز له بـR)، واستخدام الشرائط

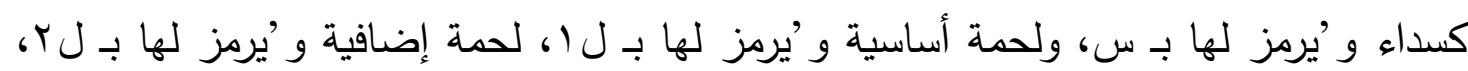
وإستخدام التركيب النسجى ثلاثى المحاور (س، ل (، ل ب)، والمحور الأول ويقصد به الإتجاه

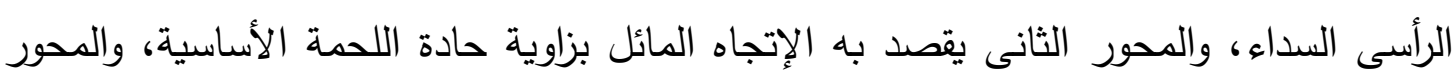
الثالث ويقصد به الإتجاه القطرى المحدد اللحمة الإضافية. r-r تنفيذ عينات النسيج ثلاثى الأبعاد:

تم استخدام الشرائط بالمواصفات المحدة بالبحث فى تتفيذ عدد (r) عينات نسيج ثلاثى

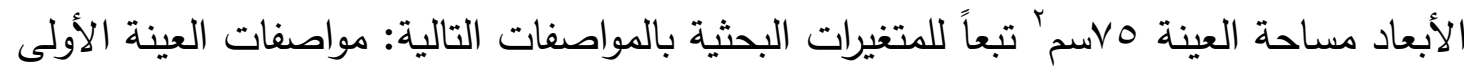

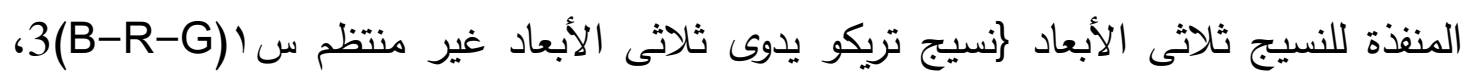

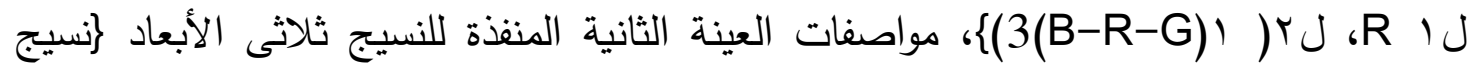
ستان يدوى ثلاثى الأبعاد منتظم س، (B-R-G)، ل ل 2(B-R-G) 2(B-R-G) ل )؛، مواصفات العينة الثالثة المنفذة للنسيج ثلاثى الأبعاد (نسيج تريكو يدوى ثلاثى الأبعاد منتظم،

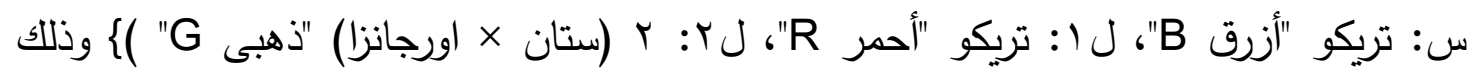
وفقاً للخطوات التالية: أ تثبيت شرائط السداء بالثمع على النول الخشبى اليدوى مساحته • بسمَّ كما موضح

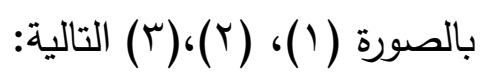
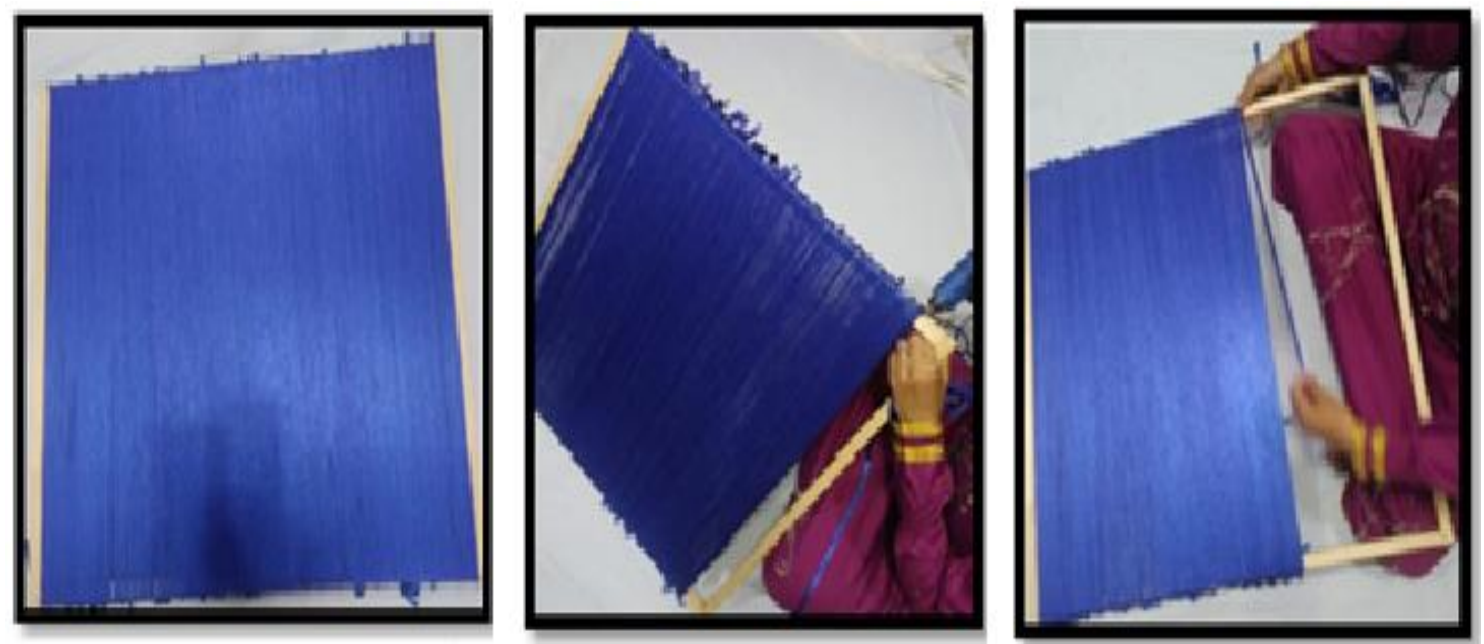

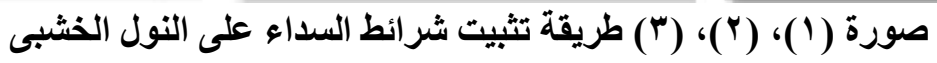

المجلد الثامن- العدد الأول- مسلسل العدد (15)- يناير 2022- الجزء الأول 


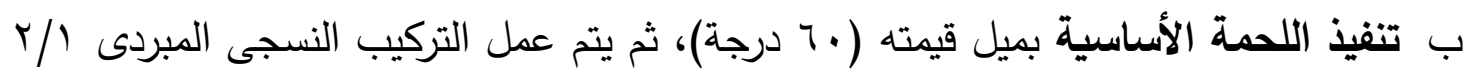

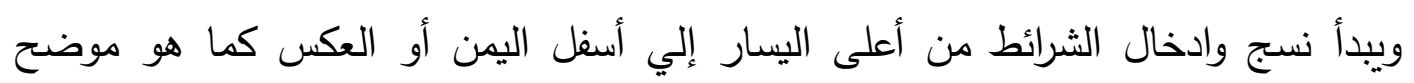
بالصورة (ع)،(0)، (؟) التالية:
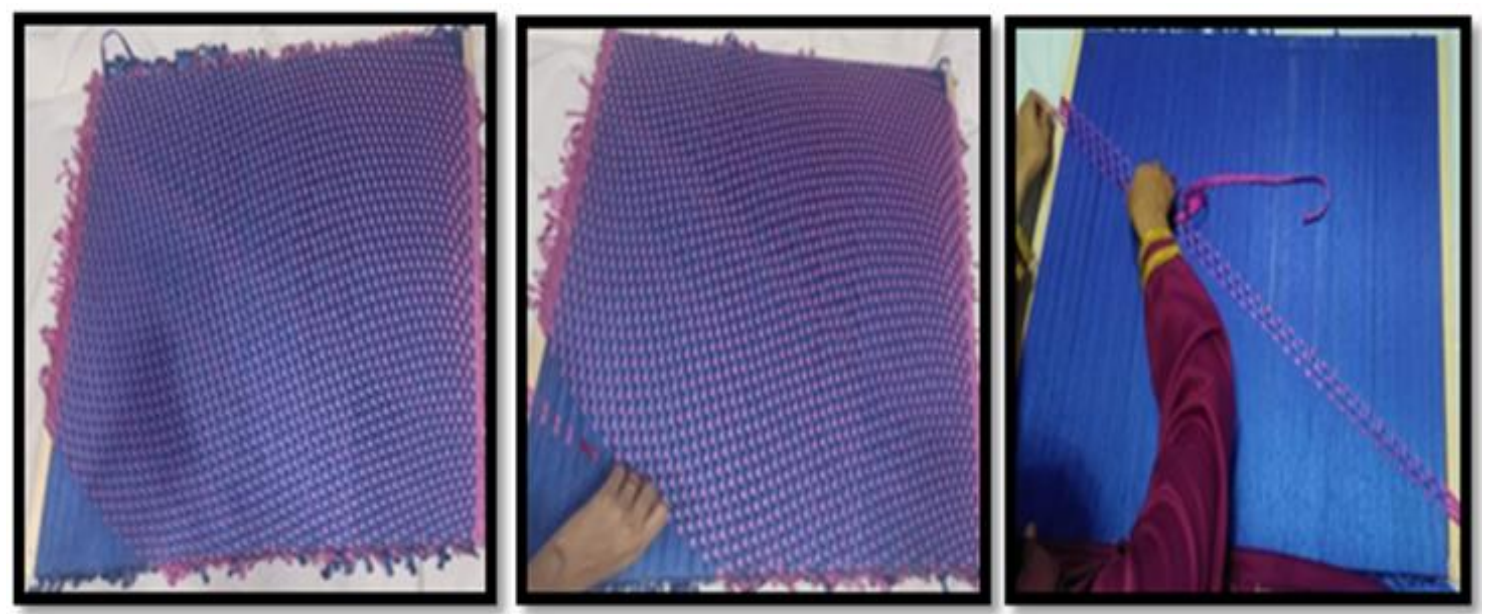

صورة (؛) )، (ه)، (") طريقة نسج وتعاشق اللحمة الأساسية مع السداء على النول الخشبى

ج - تعاشق اللحمة الإضافية بشكل قطرى مع السداء واللحمة الأساسية، تعاشق شريط واحد

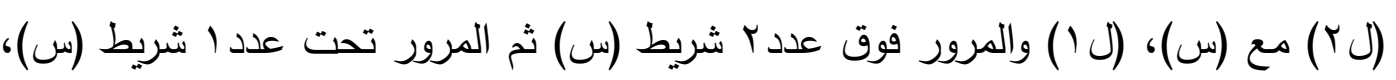

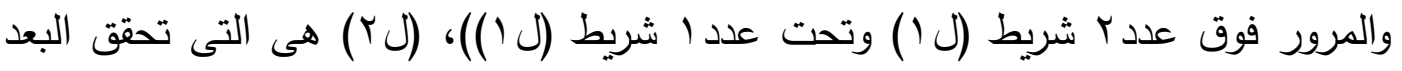
الثالث اللإيهامى كما موضح بالصورة (V)،(^)،التالية والصورة رقم (9) الثكل النهائى للتصميم النسجى المنفذ كما يلى:
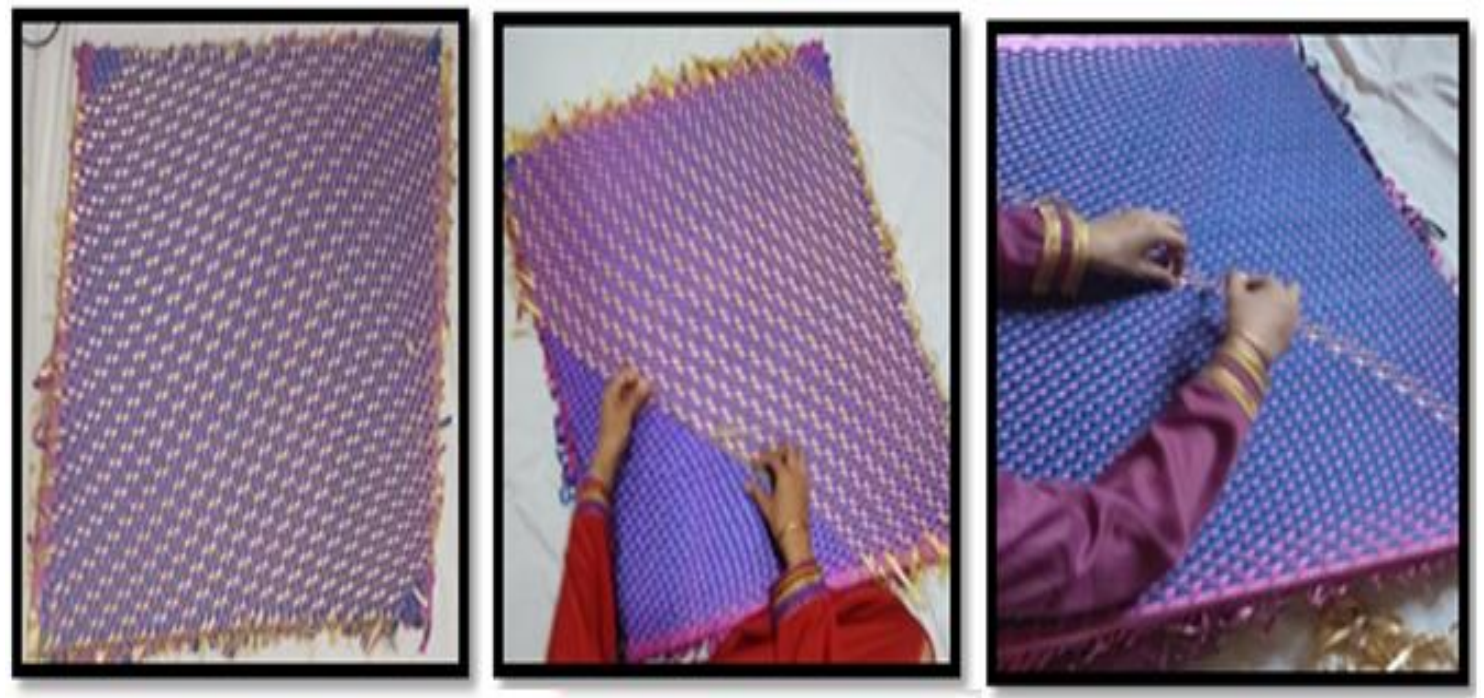

صورة (V)، (^) طريقة نسج وتعاشثق اللحمة الإضافية مع اللحمة الأساسية والسداء وصورة(9) الثنكل النهائى للنسيج المنفة ثانياً- تصميم الأزياء النسائية المقترحة: 
تصميم عدد (0) تصميمات مقترحة للأزياء النسائية الخارجية باستخدام برنامج

الفوتوشوب (Photoshop)، وتشمل التصميمات المقترحة للأزياء (جاكيت قصير بليزر، وبنطلون جينز وهاف بوت وسويت شيرت، وفستان ستان عصرى، وتيشرت شيفون وجونلة ستان، وعباءة خارجية)، ويتضح ذلك من خلال الجداول من (1-r) التالية.

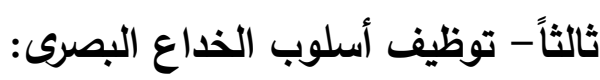
أ. توظيف الخداع البصرى الناتج عن النسيج ثلاثى الأبعاد المنفذ بالبحث وعرض إمكاناته

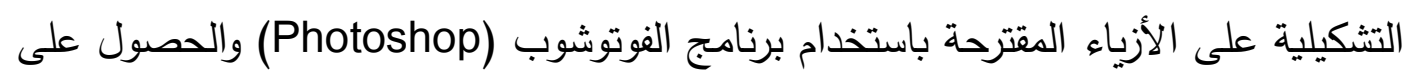
عدد (10) تصميم مقترح لأزياء السيدات الخارجية المعاصرة تتميز بالتفرد والجاذبية بالإضافة إلي إمكانية المساهمة فى إخفاء بعض العيوب الجسمية وتُرتدى فى فترات ومناسبات مختلفة. ب. تحليل وتوصيف كل من (عينات النسيج المنفذ وجماليات تثكيلها وتوظيف الخداع البصرى

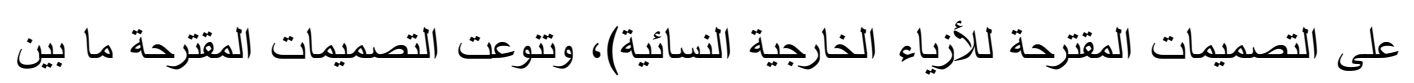
(جاكيت قصير (بليزر)،بنطلون جينز وهاف بوت وسويت شيرت، فستان ستان، تيشرت

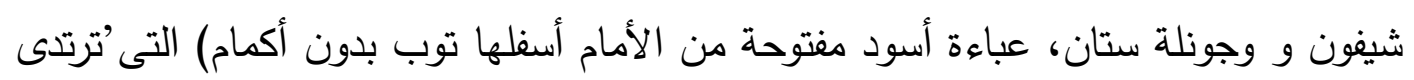

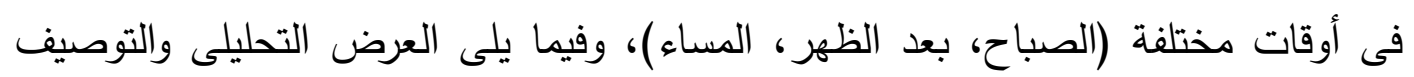

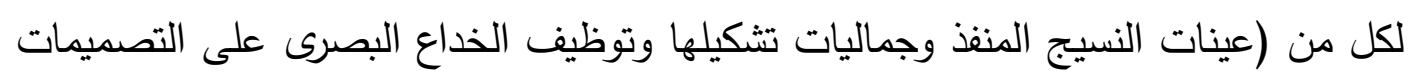
المقترحة للأزياء الخارجية النسائية) بالجداول أرقام (1-r) التالية:

جدول(1) مواصفات عينة النسيج المنفذة وتوظيف الذاع البصرى على التصميمات الأزياء النسائية

\begin{tabular}{|c|c|}
\hline عينة النسيج (1) المنفذة & مواصفات التصميم النسجى(1) \\
\hline 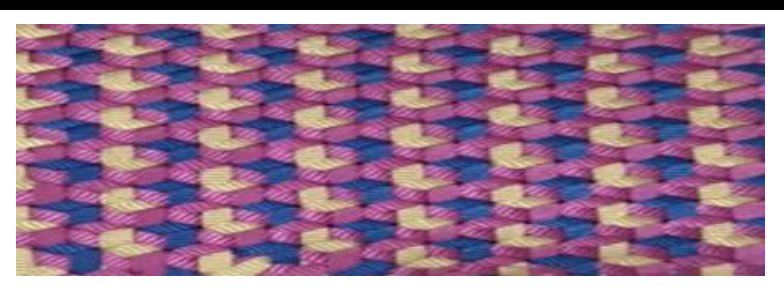 & 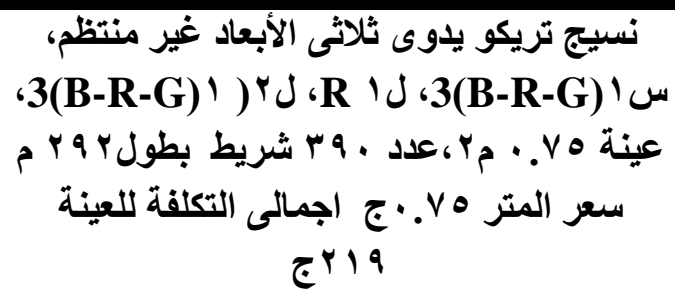 \\
\hline بوت & تصميم (1) جاكيت قصير (بليزر) \\
\hline
\end{tabular}

المجلد الثامن- العدد الأول- مسلسل العدد (15)- يناير 2022- الجزء الأول 


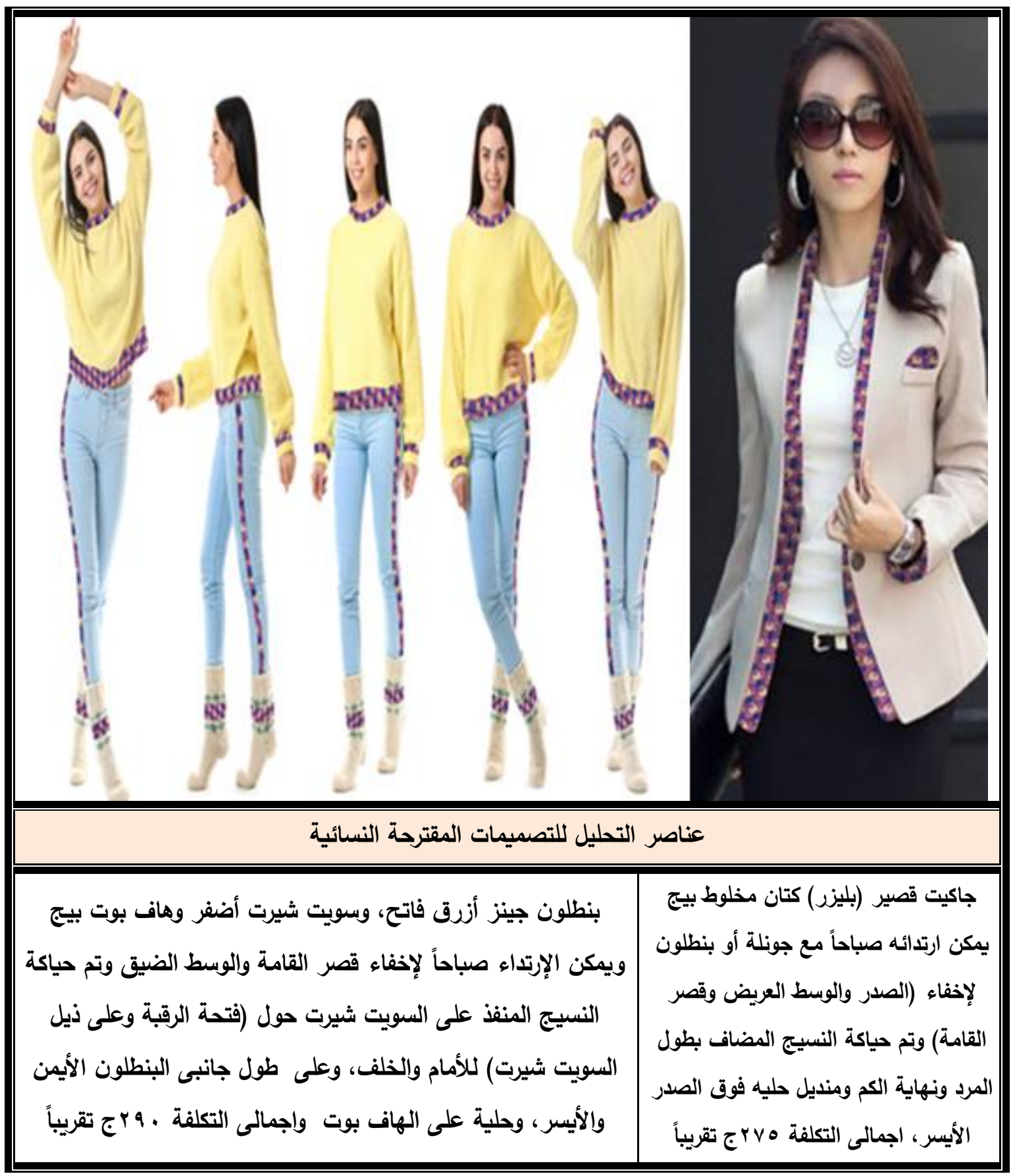

جدول(ץ) مواصفات عينة النسيج المنفذة وتوظيف الخاع البصرى على التصميمات الأزياء النسائية

\begin{tabular}{|c|c|c|c|}
\hline \multicolumn{2}{|c|}{ عينة النسيج (1) المنفذة } & \multicolumn{2}{|c|}{ مواصفات التصميم النسجى( ) } \\
\hline 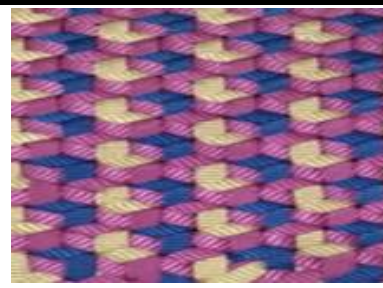 & 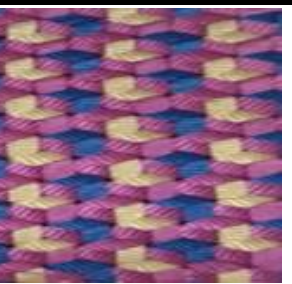 & 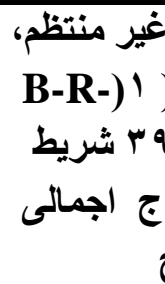 & 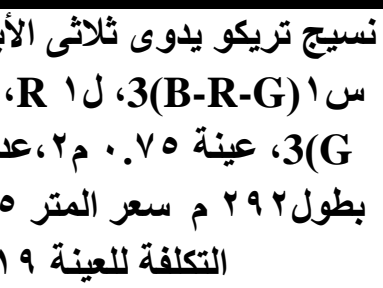 \\
\hline تصمير (ه) عباءة & شيفون وجونلةتستان & تصمي|(؛ & تصميم (ץ) فستان ستان \\
\hline
\end{tabular}

المجلد الثامن- العدد الأول- مسلسل العدد (15)- يناير 2022- الجزء الأول 


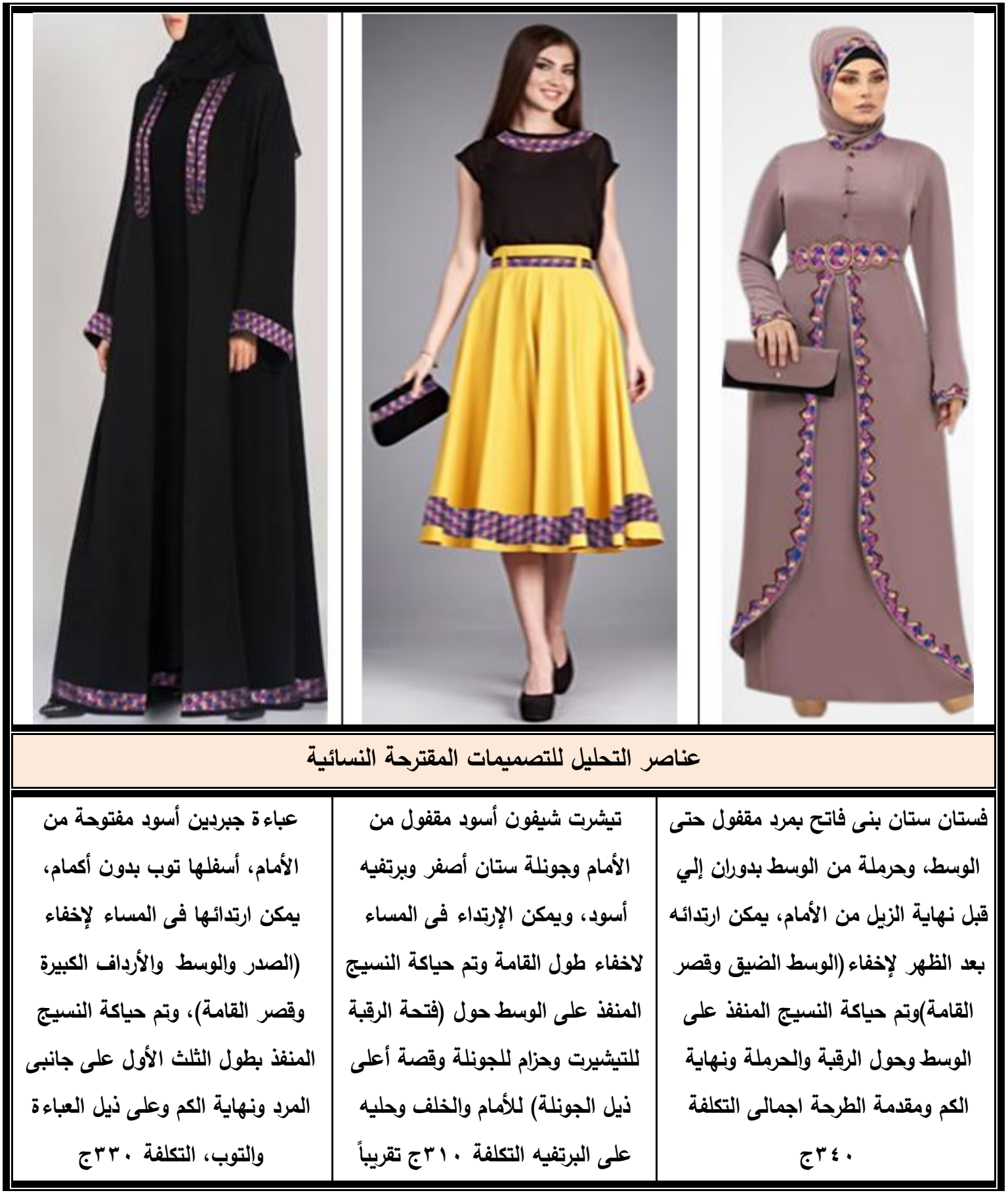

جدول(َ) توظيف أسلوب الخذاع البصرى النتائج من النسيج المنفذ علي اللأزياء المقترحة

\begin{tabular}{|c|c|}
\hline عينة النسيج (Y) المنفذة & مواصفات التصميم النسجى(ץ) \\
\hline & 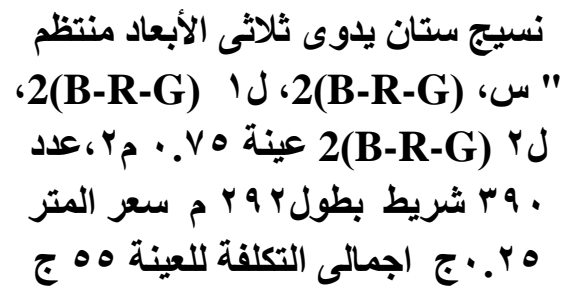 \\
\hline
\end{tabular}

المجلد الثامن- العدد الأول- مسلسل العدد (15)- يناير 2022- الجزء الأول 


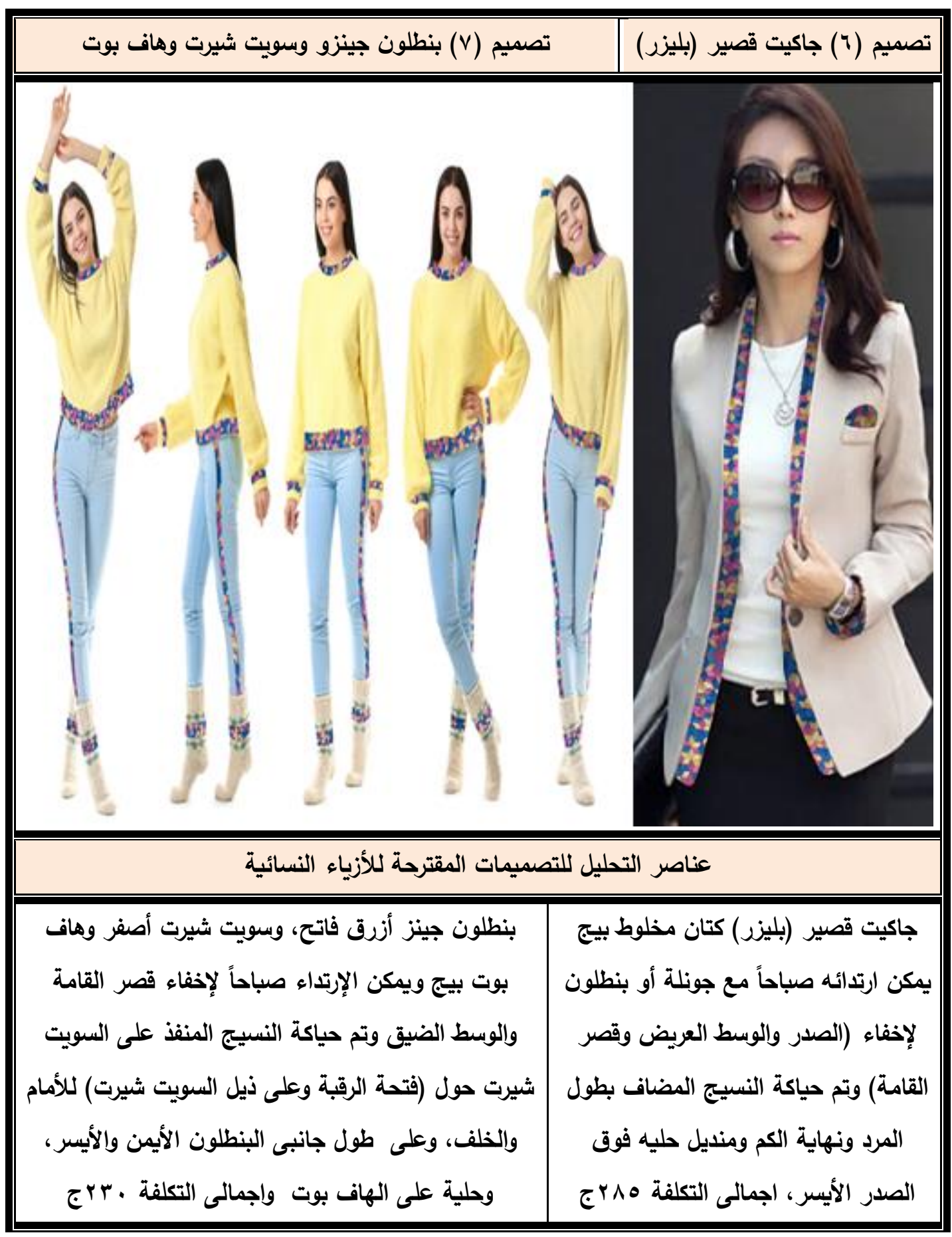

جدول(؛ ) مواصفات عينة النسيج المنفذة وتوظيف الخداع البصرى على التصميمات الأزياء النسائية

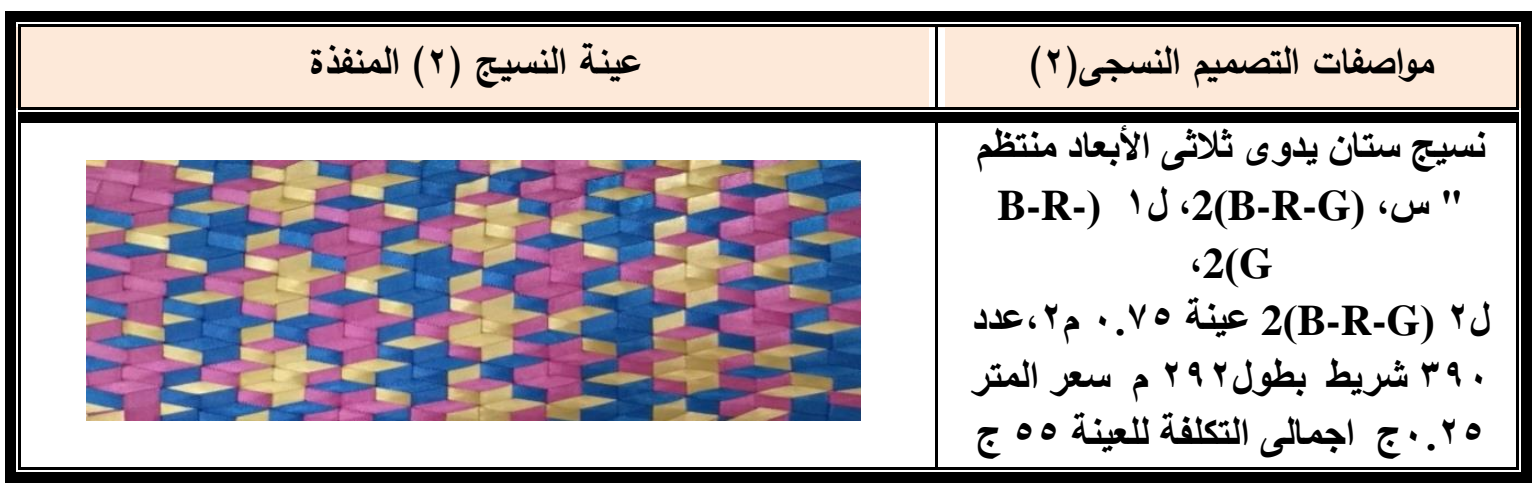

المجلد الثامن- العدد الأول- مسلسل العدد (15)- يناير 2022- الجزء الأول 


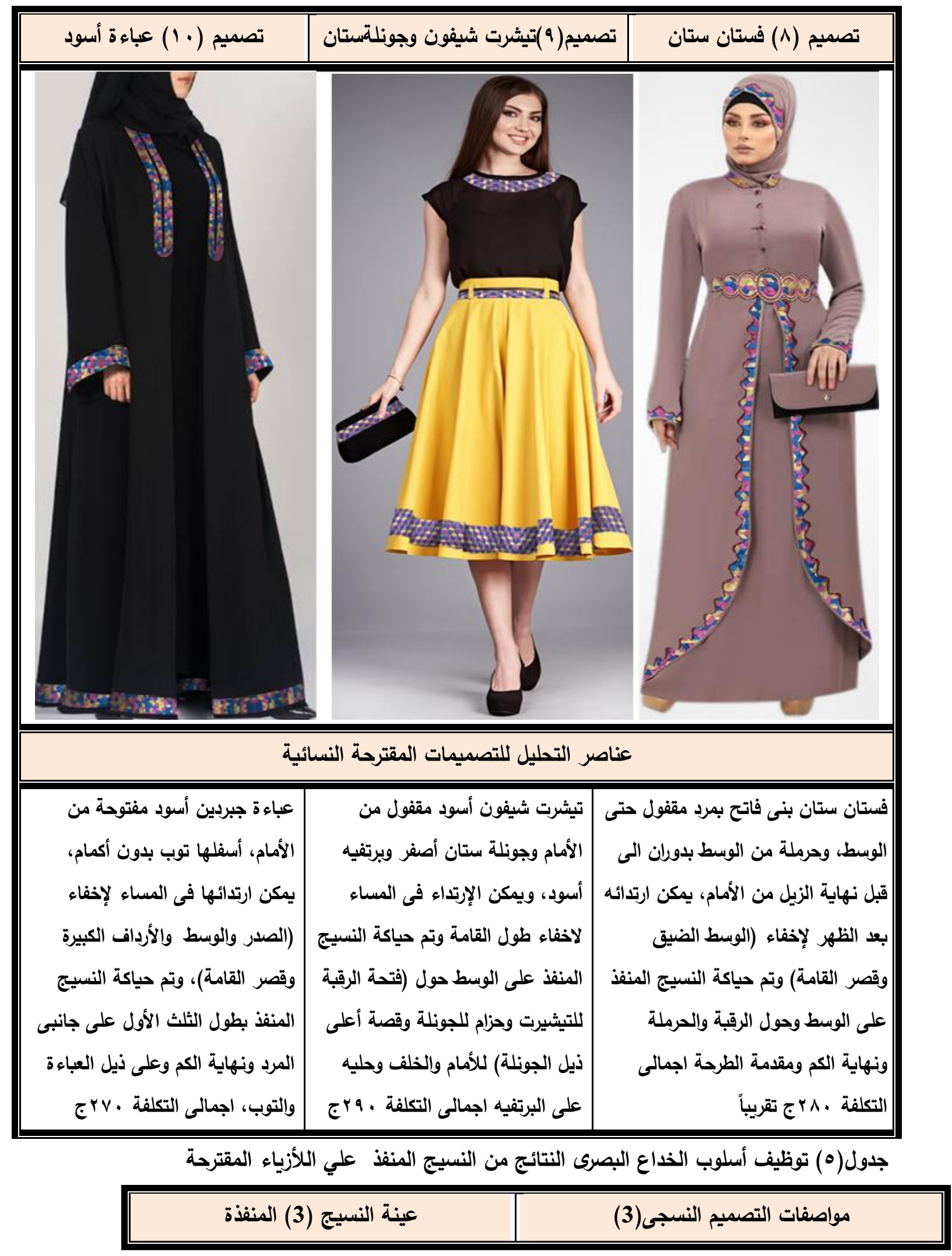

المجلد الثامن- العدد الأول- مسلسل العدد (15)- يناير 2022- الجزء الأول 


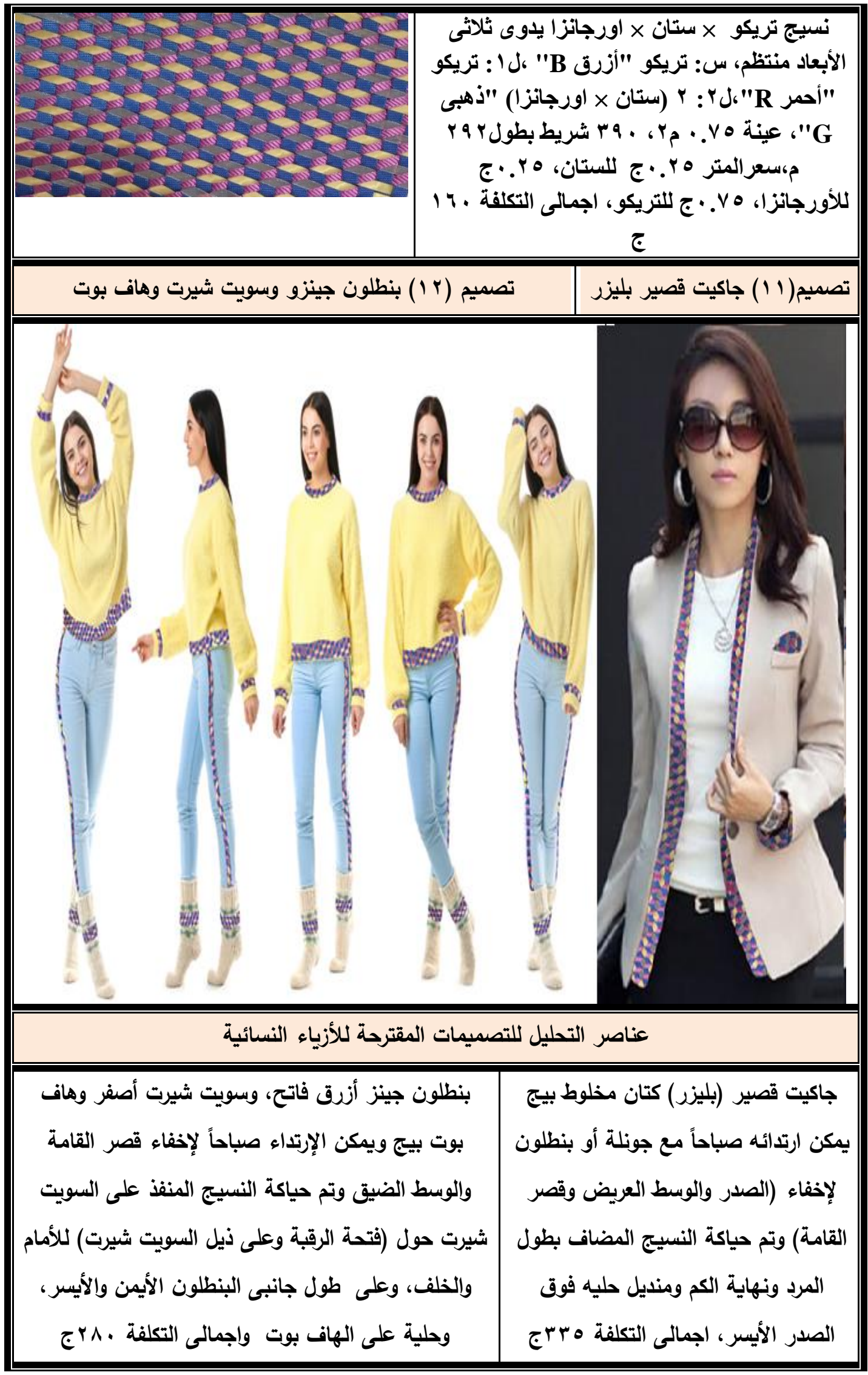

جدول(7) مواصفات عينة النسيج المنفذة وتوظيف الذاع البصرى على التصميمات الأزياء النسائية 


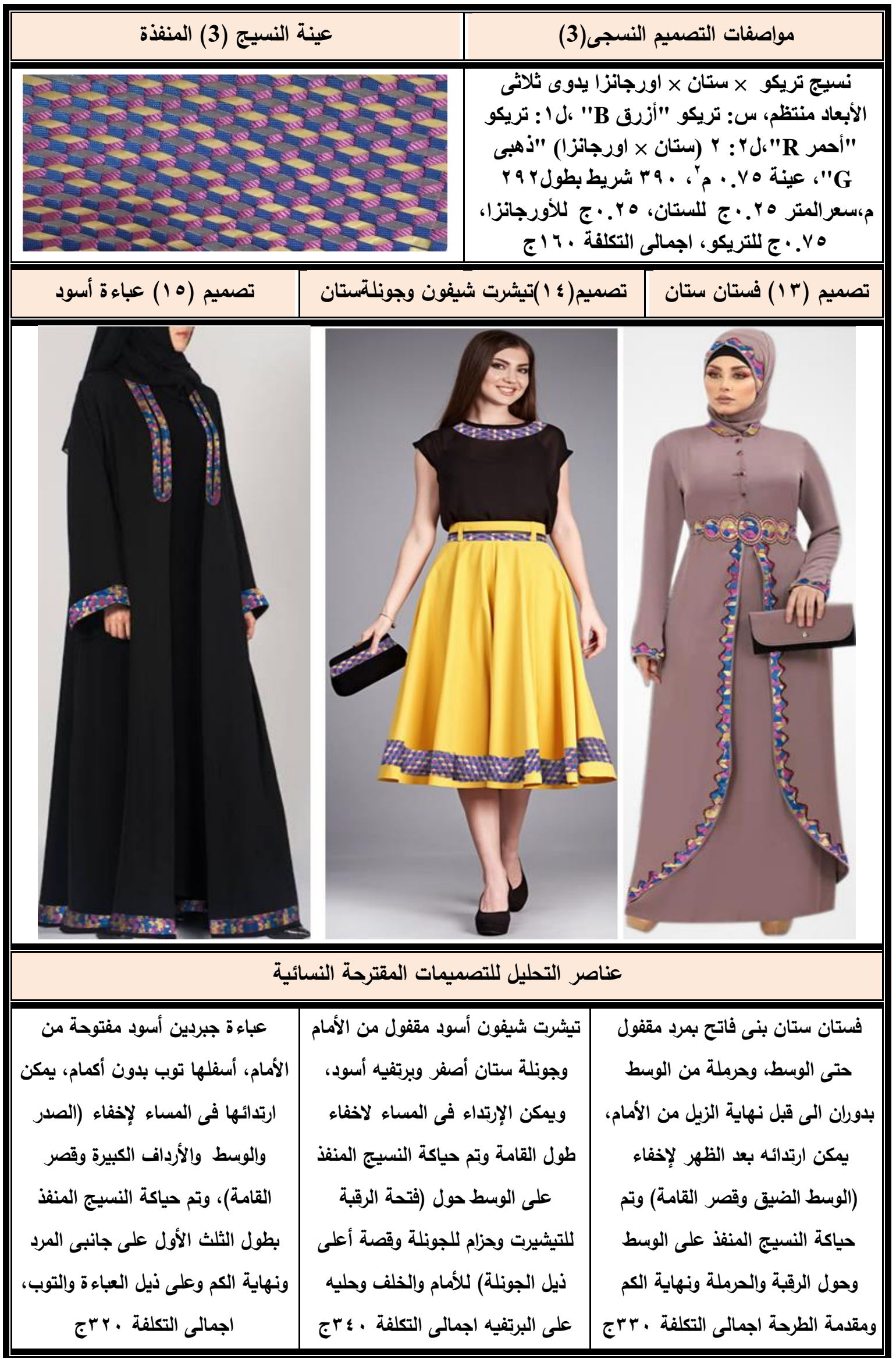

\footnotetext{
المجلد الثامن- العدد الأول- مسلسل العدد (15)- يناير 2022- الجزء الأول
} 
رابعاً- تقييم النسيج ثلاثى الأبعاد والتصميمات المقترحة للأزياء النسائية الخارجية: أ. إعداد (r) ثلاث استبيانات للتعرف على أراء المحكمين (المتخصصين، المستهلكات، أصحاب محلات بيع الملابس) فى امكانية توظيف أسلوب الخداع البصرى والإمكانات التشكيلية الناتجة النسيج المنفذ على التصميمات المقترحة للأزياء النسائية. ب. حساب الصدق والثبات لاستبيانات البحث الخاصة المحكين (المتخصصين، المستهكات، أصحاب محلات بيع الملابس) كما يلى: ج. عرض عينات النسيج ثلاثى الأبعاد وعددهم (r) عينات النسيج المنفذ وجماليات تشكيلها وتوظيف الخداع البصرى على التصميمات المقترحة للأزياء الخارجية النسائية وعددهم (10) تصميم على المحكمين المتخصصين وعينة البحث (المستهكات، أصحاب محلات بيع (الملابس). خامساً - حساب الصدق والثبات لإستبيانات: أ- استبيان المتخصصين في مجال الملابس والنسيج، تصميج الأزياء: تم إعداد استبيان لاستطلاع رأي المتخصصين في امكانية توظيف أسلوب الخداع البصرى والإمكانات التشكيلية

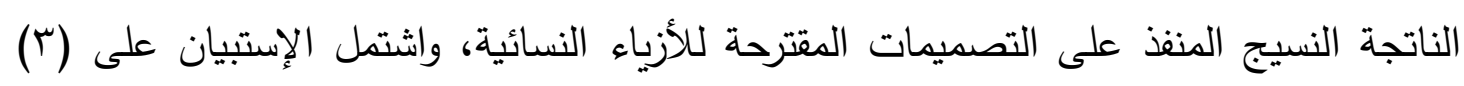
محاور وكل محور يتضمن (0) عبارات، والمحور الأول خاص بالخداع البصرى، والمحور

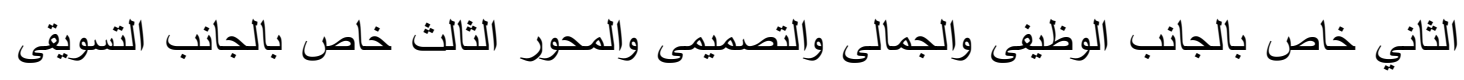
والإقتصادى، وبذللك يكون مجموع عبارات الإستبان (0) عبارة بموجب (0؛ ) درجة، ويتكون

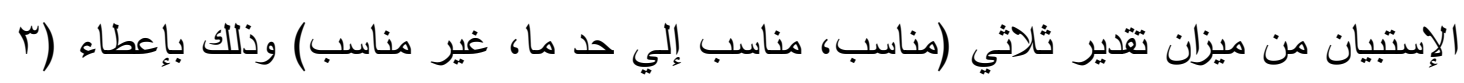
درجات لمناسب، Ү درجة إلي مناسب إلي حد ما، ( درجة واحدة لغير مناسب). - صدق الإستبيان: تم التحقق من صدق الإستبيان باستخدام نوعين من الصدق "صدق المحكمين، الصدق الإحصائي". - صدق المحكين: تم عرض الصورة المبئية للإستبيان علي مجموعة من التتخصين في مجال الملابس والنسيج والتحقق من صدق محتواها وإبداء الرأي فيها من حيث (سلامة ووضوح الصياغة اللغوية للعبارات، سلامة الصياغة العلمية للعبارات، التسلسل المنطقي للعبارات داخل

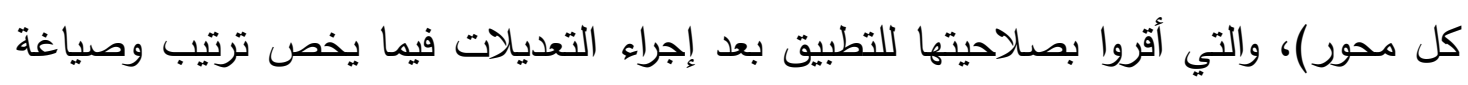
بعض العبارات، والجدول (7) التالى يوضح نسب الإتفاق كما يلى: 
جدول (7) نسب اتفاق المحكمين علي بنود إستبانة آراء المتخصصين

\begin{tabular}{|c|c|c|c|c|}
\hline النسبة المئوية & عدم الاتفات مرات & مرات الاتفاق & بنود التحكيم & p \\
\hline $93.33 \%$ & 1 & 14 & سلامة ووضوح الصياغة اللغوية للعبارات. & 1 \\
\hline $93.33 \%$ & 1 & 14 & سلامة الصياغة العلمية للعبارات & r \\
\hline $100 \%$ & $\mathbf{0}$ & 15 & التسلسل المنطقي للعبارات داخل كل محور & $r$ \\
\hline
\end{tabular}

يتضح من الجدول (7) إرتفاع نسب اتفاق المحكمين علي بنود الإستبيان حيث تراوحت ما

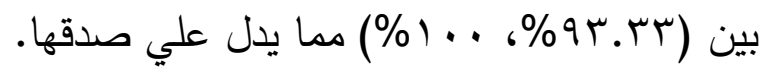
- صدق الإتساق الأخلي (الصدق الإحصائي): تم حساب الصدق باستخدام الإتساق الداخلي وذلك بحساب معامل الإرتباط (معامل ارتباط بيرسون) بين درجة كل محور والدرجة الكلية

$$
\text { للإستبيان، والجدول (8) التالي يوضح ذلك: }
$$

جدول (8) قيم معاملات الإرتباط بين درجة كل محور والدرجة الكلية لإستبان آراء المتخصصين

\begin{tabular}{|c|c|c|}
\hline الالالة & الإرتباط & محاور الإستبيان \\
\hline 0.03 & $0.865 * *$ & جانب الذداع البصرى \\
\hline 0.01 & $0.869 * *$ & الجانب الوظيفى والجمالى والتصميمى \\
\hline 0.02 & $0.872 * *$ & الجانب التسويقى والإقتصادى \\
\hline
\end{tabular}

يتضح من جدول (8) أن معاملات الإرتباط دالة عند مستوي (1 (..)، ودالة عند مستوي (0 . . •)، وبذلك يوجد هنالك إتساق داخلي بين محاور الإستبيان، كما أنه يقيس بالفعل ما 'وضع لقياسه مما يدل علي صدقه وتجانسه.

- ثبات الإستبيان: تم حساب الثبات عن طريق معامل ألفا كرونباخ وطريقة التجزئة النصفية

$$
\text { وجدول(9) التالى يوضتح ذلك: }
$$

\begin{tabular}{|c|c|c|c|c|}
\hline \multicolumn{2}{|c|}{ التجزئة النصفية } & \multicolumn{2}{|c|}{ معامل ألفا كرونباخ } & \multirow{2}{*}{ محاور الإستبيان } \\
\hline الدلالة & الإرتباط & الدالة & الإرتباط & \\
\hline 0.034 & $\begin{array}{c}0.954- \\
0.865\end{array}$ & 0.01 & $0.874 * *$ & جانب الذداع البصرى \\
\hline
\end{tabular}

جلول (9) قيم معاملات ألفا كرونباخ والتجزئة النصفية لإستبان آراء المتخصصين

المجلد الثامن- العدد الأول- مسلسل العدد (15)- يناير 2022- الجزء الأول 


\begin{tabular}{|c|c|c|c|c|}
\hline 0.022 & $\begin{array}{l}0.942- \\
0.828\end{array}$ & 0.01 & $0.827 * *$ & الجانب الوظيفى والجمالى \\
\hline 0.021 & $\begin{array}{c}0.951- \\
0.874\end{array}$ & 0.01 & $0.882 * *$ & الجانب التسويقى والإقتصادى \\
\hline 0.012 & $\begin{array}{r}0.923- \\
0.834\end{array}$ & 0.01 & $0.861 * *$ & مجموع الإستبيان ككل \\
\hline
\end{tabular}

يتضـح مـن جدول (9) السـابق أن جميع قيم معـاملات الثبـات معامـل ألفاكرونبـاخ،

التجزئة النصفية، دالة عند مستوي (1 ...) مما يدل علي أن الإستبيان تتمتع بدرجة عالية من

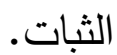

ب- استبيان المستهات: تم إعداد استبيان لاستطلاع رأي المستهلكات في امكانية توظيف أسلوب الخداع البصرى والإمكانات التشكيلية الناتجة النسيج المنفذ على التصميمات المقترحة للأزياء النسائية، واشتمل الإستبيان علي تقييم (10) عبارة، وقد استخدم ميزان تقدير ثلاثي (مناسب، مناسب إلي حد ما، غير مناسب) وذللك بإعطاء (r درجات لدناسب، ؟ درجة إلي مناسب إلي حد ما، ( درجة واحدة لغير مناسب)، وكانت الدرجة الكلية للإستبيان (0؛) درجة. - صدق محتوي الإستبيان: للتحقق من صدق محتوي الإستبيان تم عرضه في صورته المبدئية علي مجموعة من المحكمين من أساتذة الملابس والنسيج، وذلك لأبداء الرأي في محتواه ومدي الإنيان توافر النقاط التالية: صياغة العبارات ومدي صلاحيتها للحكم علي التصميمات المقترحة لإثراء القيم الجمالية والوظيفية للملابس الخارجية الحريمى.

جدول (10) معامل اتفاق السادة المتخصصين علي بنود استبيان تقييم التصميمات المقترحة لإثراء القيم الجمالية والوظيفية للأزياء النسائية

\begin{tabular}{|c|c|c|c|}
\hline معامل الاتفاق & عدم الاتفاق & عداد مرات & 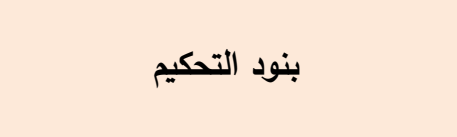 \\
\hline $93.33 \%$ & 1 & 14 & الدقة في الصياغة اللغوية للعبارات. \\
\hline $93.33 \%$ & 1 & 14 & سهولة ووضوح العبارات. \\
\hline $100 \%$ & $\mathbf{0}$ & 15 & ملاءمة الصياغة العلمية للعبارات. \\
\hline
\end{tabular}

المجلد الثامن- العدد الأول- مسلسل العدد (15)- يناير 2022- الجزء الأول 
يتضـح من خلال جدول (10) طريقة حساب معامل اتفاق المتخصصين البالغ عددهم

(Y. ) وحساب ثبات الملاحظين لتحديد بنود التحكيم التي يتم تتفيذها بشرط أن يسجل كل منهم ملاحظاته مستقلا عن الآخر، وتم تحديد عدد مرات الاتفاق بين الملاحظين باستخدام معادلة كوبر Cooper: نسبة الاتفاق= (عدد مرات الاتفاق / (عدد مرات الاتفاق + عدد مرات عدم

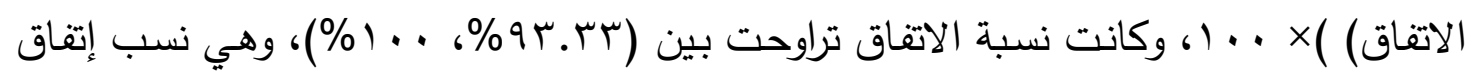
مقبولة. - الصدق باستخدام الإتساق الاخلي بين درجة كل عبارة والدرجة الكلية للإستبيان: تـم حسـاب الصدق باستخدام الإتساق الداخلي وذلك بحساب معامل الإرتباط بيرسون بين درجة كل عبارة، والدرجة الكلية للإستبيان، والجدول(11) التالي يوضح ذلك:

جدول (11) قيم معاملات الإرتباط بين درجة كل عبارة ودرجة الإستبيان

\begin{tabular}{|c|c|}
\hline الإرتباط & العبارة \\
\hline $0.824^{* *}$ & ملاءمة الألوان والخامات المستخدمة فى التصميم \\
\hline $0.888 * *$ & الترابط والإنسجام والتناسب بين النسيج المضاف والتصميم \\
\hline $0.865^{* *}$ & ملاءمة التصميم لإخفاء بعض العيوب الجسمية \\
\hline $0.860 * *$ & تحقيق الجاذبية والتشويق والخداع البصرى \\
\hline $0.806 * *$ & التنوع والتجديد فى القيمة المضافة \\
\hline $0.888 * *$ & توافق التقنية المضافة مع التصميم \\
\hline $0.850 * *$ & إثراء الجانب الوظيفى للتصميم \\
\hline $0.860 * *$ & إثراء الجانب الجمالى للتصميم \\
\hline $0.877 * *$ & جودة وحداثة التصميم \\
\hline $0.865 * *$ & تناسب التصميم مع المتطلبات الملبسية للمستهلك \\
\hline $0.760 * *$ & توافق التصميم مع الذوق العام وثقافة المجتمع \\
\hline $0.806 * *$ & انفراد وتميز التصميم عما هو متاح بالأسواق \\
\hline $0.878 * *$ & ملاءمة التكلفة مع القدرة الثرائية للمستهلك \\
\hline $0.750 * *$ & تماشيه مع إتجاهات الموضة \\
\hline
\end{tabular}

المجلد الثامن- العدد الأول- مسلسل العدد (15)- يناير 2022- الجزء الأول 


\subsection{4** امكانية تسويق التصميم وترويجه}

تبين من جدول (11) أن معاملات الإرتباط كلها دالة عند مستوي (1 ... ) لإقترابها من

الواحد الصحيح، ومن ثم يمكن يوجد اتساق داخلي بين العبارات المكونة لهذا الإستبيان، كما أنه يقيس بالفعل ما وضع لقياسه، مما يدل علي صدق وتجانس محاور الإستبيان. - ثبات الإستبيان: تم حساب الثبات عن طريق معامل ألفا كرونباخ، وطريقة التجزئة النصفية. دول (12) قيم معامل الثبات لمحاور الإستبيان

\begin{tabular}{||c|c|c||}
\hline ثبات الإستبيان ككل & معامل التفزئة النصفية & \\
\hline $0.932-$ & & \\
0.847 & & \\
\hline
\end{tabular}

تم حساب ثبات الإستبيان من جدول (12) بمعامل ارتباط ألفا فكانت قيمته . 1.1. .

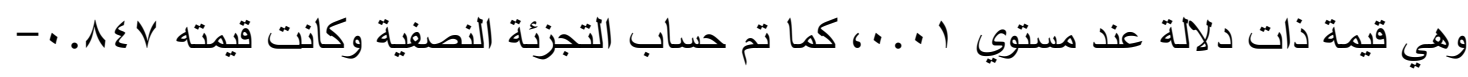
با9. · وهي قيمة ذات دلالة عند مستوي ا ... مما يشير إلي أن الإستبيان يتمتع بدرجة عالية من الثبات.

ج- استبيان تقييم أصحاب محلات بيع الملابس: تم إعداد استبيان لاستطلاع رأي أصحاب محلات بيع الملابس في امكانية توظيف أسلوب الخداع البصرى والإمكانات التشكيلية الناتجة النسيج المنفذ على التصميمات المقترحة للأزياء النسائية، واشتمل الإستبيان علي تقييم (10) عبارة، وقد استخدم ميزان تقدير ثلاثي (مناسب، مناسب إلي حد ما، غير مناسب) وذلك بإعطاء (r درجات لمناسب، r درجة إلي مناسب إلي حد ما، ا درجة واحدة لغير مناسب)، بإجمالى

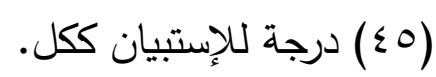

- صدق محتوي الإستبيان: تم التحقق من صدق محتوي الإستبيان بعرضه في صورته المبدئية

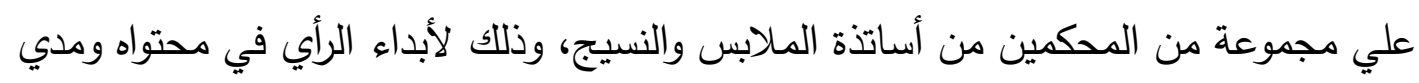
توافر النقاط التالية: صياغة العبارات ومدي صلاحيتها للحكم علي التصميمات المقترحة لإثراء القيم الجمالية والوظيفية للأزياء النسائية.

جدول (r ا ) معامل اتفاق السادة المتخصصين علي بنود استبيان تقييم التصميمات المقترحة لإثراء القيم الجمالية والوظيفية للأزياء النسائية

\begin{tabular}{|c|c|c|c|}
\hline معامل & عدد مرات & عدد مرات & بنود التحكيم \\
\hline
\end{tabular}

المجلد الثامن- العدد الأول- مسلسل العدد (15)- يناير 2022- الجزء الأول 
مجلة دراسات وبحوث التربية النوعية

\begin{tabular}{|c|c|c|c|c|}
\hline الاتفاق & عل ع ام الاتفاق & الاتفاق & & \\
\hline $93.33 \%$ & 1 & 14 & الدقة في الصياغة اللغوية & 1 \\
\hline $93.33 \%$ & 1 & 14 & سهولة ووضوح العبارات. & r \\
\hline $100 \%$ & $\mathbf{0}$ & 15 & ملاءمة الصياغة العلمية للعبارات. & r \\
\hline
\end{tabular}

ويتضح من جدول (r ا أنه تم استخدام طريقة اتفاق المتخصصين البالغ عددهم (·r) في

حسـاب ثبات الملاحظين لتحديد بنـود التحكيم التي يتم تتفيذها بشـرط أن يسـل كل مـنهم ملاحظاته مستقلا عن الأخر ، وتم تحديد عدد مرات الاتفاق بين الملاحظين باستخدام معادلة كوبر Cooper: نسبة الاتفاق= (عدد مرات الاتفاق / (عدد مرات الاتفاق + عدد مرات عدم الاتفاق) )× × . (، وكانت نسبة الاتفاق تراوحت بين (rr.ب9\%، . . ( \%\%)، وهي نسب اتفاق مقبولة. - الصدق باستخدام الإتساق الداخلي بين درجة كل عبارة والدرجة الكلية للإستبيان: تم حساب الصدق باستخدام الإتساق الداخلي وذلك بحساب معامل الإرتباط بيرسون بين درجة كل عبارة،

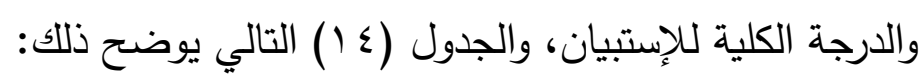
جدول (ء ) قيم معاملات الإرتباط بين درجة كل عبارة ودرجة الإستبيان

\begin{tabular}{|c|c|}
\hline الإرتباط & العبارة \\
\hline $0.824 * *$ & ملاءمة الألوان والخامات المستخدمة فى التصميم \\
\hline $0.888 * *$ & الترابط والإنسجام والتناسب بين النسيج المضاف والتصميم \\
\hline $0.865^{* *}$ & ملاءمة التصميم لإخفاء بعض العيوب الجسمية \\
\hline $0.860 * *$ & تحقيق الجاذبية والتثويق والخذاع البصرى \\
\hline $0.806 * *$ & التتوع والتجديد فى القيمة المضافة \\
\hline $0.888 * *$ & توافق التقنية المضافة مع التصميم \\
\hline $0.850 * *$ & إثراء الجانب الوظيفى للتصميم \\
\hline $0.860 * *$ & إثراء الجانب الجمالى للتصميم \\
\hline $0.877 * *$ & جودة وحداثة التصميم \\
\hline $0.865 * *$ & تناسب التصميم مع المتطلبات الملبسية للمستهلك \\
\hline
\end{tabular}

المجلد الثامن- العدد الأول- مسلسل العدد (15)- يناير 2022- الجزء الأول 


\begin{tabular}{|c|c|}
\hline $0.760 * *$ & توافق التصميم مع الذوق العام وثقافة المجتمع \\
\hline $0.806 * *$ & انفراد وتميز التصميم عما هو متاح بالأسواق \\
\hline $0.878 * *$ & ملاءمة التكلفة مع القدرة الشرائية للمستهلك \\
\hline $0.750 * *$ & تماشيه مع إتجاهات الموضة \\
\hline $0.764 * *$ & امكانية تسويق التصميم وترويجه \\
\hline
\end{tabular}

تبين من جدول(ع () السـابق أن معاملات الإرتباط كلها دالة عند مستوي (1 ...) لإقترابها من الواحد الصحيح، ومن ثم يمكن القول أن هناك اتساق داخلي بين العبارات المكونة لهذا الإستبيان، كما أنه يقيس بالفعل مـا وضـع لقياسـ، مما يدل علي صدق وتجانس محاور الإستبيان.

- ثبات الإستبيان: تم حساب الثبات عن طريق معامل ألفا كرونباخ وطريقة التجزئة النصفية جدول (10) قيم معامل الثبات لمحاور الإستبيان

\begin{tabular}{|c|c|c|}
\hline ثبات الإستبيان ككل & \\
\hline $0.932-$ & $0.850 \% *$ & \\
0.847 & & \\
\hline
\end{tabular}

تم حسـاب ثبات الإستبيان مـن جدول(10) السـابق بمعامل ارتباط ألفا فكانت قيمتهـ •1.. • وهي قيمة ذات دلالة عند مستوي ا ...، كما تم حساب التجزئة النصفية وكانت قيمته

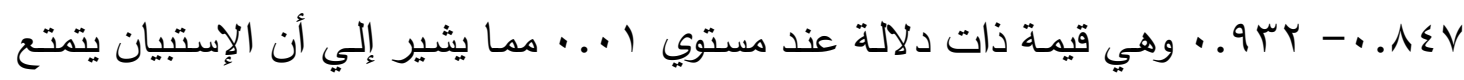
بدرجة عالية من الثبات. المعالجات الإحصائية: تم تحليل البيانات وإجراء المعاملات الإحصائية باستخدام برنامج Spss لاستخراج النتائج، واستخدام معامل إرتباط بيرسون لحساب الصدق ومعامل ألفا كرونباخ لحساب الثبات، وتم حساب المتوسط المرجح والمتوسط المئوى المرجح (معامل الجودة)، والمتوسط الحسابي والإنحراف المعيارى وتحليل التباين (ANOVA) تحليل التباين لتتييم آراء المتخصصين فى المجال فى التصميمات المقترحة للأزياء النسائية بالبحث بحساب متوسطات المربعات وقيمة (ف) ومستوي الدالة عند ا...، وحساب الإنحراف المعياري ومعامل الجودة لترتيب النسيج 
المستحدث المنفذ والتصميمات المقترحة لأزياء النسائية من قبل المتخصصين والمستهلكات وأصحاب محلات بيع الملابس الخارجية.

\section{النتائج والمناقشية:}

الفرض الأول: توجد فروق ذات دلالة إحصائية وفقاً لأراء المتخصصين بين امكانية توظيف الخداع البصرى النسجى على التصميمات المقترحة للأزياء النسائية بالبحث فى تحقيق جوانب

أولاً -جانب الخذاع البصرى: للتحقق من صحة هذا الفرض تم حساب تحليل التباين للتصميمات المقترحة ككل في تحقيق جوانب التقييم ككل وفقا لأراء المحكمين والجدول (7 ( ) التالي يوضح ذلك، فتم حساب مجموع تقييمات المتخصصين وعددهم(·r) من أساتذة التخصص في مجال الملابس والنسيج وتصميم الأزياء لتصميمات الملابس الخارجية للسيدات المنفذة من توظيف النسيج ثلاثي الأبعاد وذلك في تحقيق جانب الخداع البصرى كما يلى:

جدول (7 1 ) تقييمات المتخصصين المتخصصين لامكانية توظيف الخداع البصرى النسجى على التصميمات المقترحة للأزياء النسائية بالبحث فى تحقيق جانب الذاع البصرى

\begin{tabular}{|c|c|c|c|c|c|c|c|c|c|c|c|c|c|c|c|}
\hline \multicolumn{5}{|c|}{ نسيج مخلوط يدوى ثلاثى الأبعاد منتظر } & \multicolumn{5}{|c|}{ 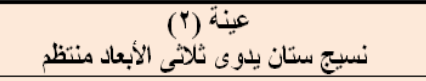 } & \multicolumn{5}{|c|}{ نسيج تريكو يدوى ثلاثي الأبعاد غير منتظم } & \multirow{3}{*}{ لمؤشر } \\
\hline 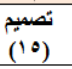 & تصميم & تصمبي & تصمبي & تصمبي & $\begin{array}{l}\text { تصمبي } \\
\text { (1.) }\end{array}$ & تصميِ & تصمِ & تصميم & تصميم & تصميم & تصميح & تصميم (") & 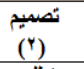 & تصميم & \\
\hline عباءة & وجثئلة & فستان & شيرويتّ & جاكيت & عباءة & توجئنيرت & فستان & شبونتوت & جاكيت & عباءة & توجئنيرت & فستان & 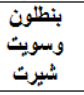 & جاكيت & \\
\hline 56 & 53 & 55 & 54 & 57 & 48 & 48 & 47 & 47 & 48 & 52 & 49 & 50 & 51 & 52 & 1 \\
\hline 55 & 54 & 54 & 53 & 56 & 46 & 48 & 45 & 45 & 46 & 50 & 50 & 51 & 50 & 50 & 2 \\
\hline 56 & 55 & 53 & 55 & 57 & 45 & 47 & 46 & 46 & 45 & 50 & 50 & 50 & 52 & 49 & 3 \\
\hline 55 & 55 & 53 & 53 & 55 & 42 & 47 & 47 & 47 & 42 & 51 & 49 & 50 & 52 & 51 & 4 \\
\hline 56 & 53 & 54 & 45 & 57 & 48 & 46 & 45 & 45 & 48 & 51 & 51 & 49 & 51 & 51 & 5 \\
\hline
\end{tabular}

تم حساب تحليل التباين لمتوسط تقييم تصميمات الملابس الخارجية للسيدات المنفذة من توظيف النسيج ثلاثي الأبعاد وذلك في تحقيق جانب الخداع البصرى وفقا لآراء المتخصصين وجدول (IV) - ميوضح ذلك:

جدول(IV) تحليل التباين لمتوسط تقييم المتخصصين لامكانية توظيف الخداع البصرى النسجى على التصميمات المقترحة للأزياء النسائية بالبحث فى تحقيق جانب الخداع البصرى 
مجلة دراسات وبحوث التربية النوعية

\begin{tabular}{|c|c|c|c|c|c|}
\hline الدلالة & قيمة "ف" & المربعات & الحرية & مجموع المربعات & مصدر التباين \\
\hline \multirow{3}{*}{.000} & \multirow{3}{*}{25.892} & 65.248 & 14 & 913.467 & بين المجموعات \\
\hline & & 2.520 & 60 & 151.200 & داخل المجموعات \\
\hline & & & 74 & 1064.667 & الكلي \\
\hline
\end{tabular}

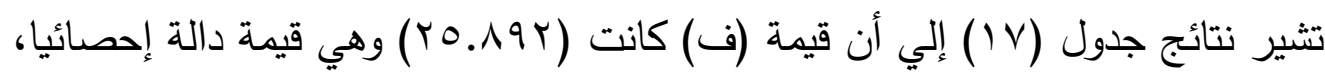

مما يدل علي وجود فروق بين تصميمات الملابس الخارجية للسيدات المنفذة من توظيف النسيج ثلاثي الأبعاد في تحقيق جانب الخداع البصرى وفقا لآراء المتخصصين.

جدول(^1) المتوسطات ومعامل الجودة لتقييم المتخصصين لامكانية توظيف الخداع البصرى النسجى

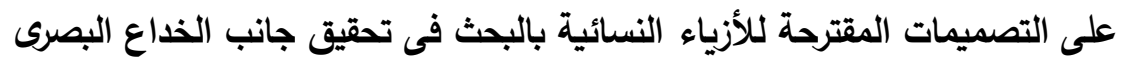

\begin{tabular}{|c|c|c|c|c|c|}
\hline ترتيب & معامل & الانحراف & المتوسط & تصميمات الملابس الخارجية للسيدات & \\
\hline 8 & 84.33 & 1.14 & 50.60 & تصميم (1) جاكيت بليزر & \multirow{5}{*}{ 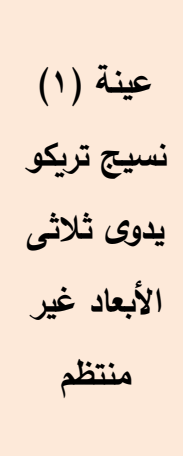 } \\
\hline 6 & 85.33 & 0.84 & 51.20 & تصميم (؟) بنطلون أسبور وسويت شيرت & \\
\hline 9 & 83.33 & 0.71 & 50.00 & تصميم (ץ) فستان كلاسيك & \\
\hline 10 & 83.00 & 0.84 & 49.80 & تصميم (؛) تيشيرت وجونلة & \\
\hline 7 & 84.67 & 0.84 & 50.80 & تصميم (•) عباءة خارجية & \\
\hline 14 & 76.33 & 2.49 & 45.80 & تصميم (؟) جاكيت بليزر & \multirow{5}{*}{ يديج الأبعاد ثلاثى ستان } \\
\hline 12 & 76.67 & 1.00 & 46.00 & تصميم (v) بنطلون أسبور وسويت شيرت & \\
\hline 13 & 76.67 & 1.00 & 46.00 & تصميم (^) فستان كلاسيك & \\
\hline 11 & 78.67 & 0.84 & 47.20 & تصميم (9) تيشيرت وجونلة & \\
\hline 15 & 76.33 & 2.49 & 45.80 & تصميم (• 1) عباءة خارجية & \\
\hline 1 & 94.00 & 0.89 & 56.40 & تصميم (1') جاكيت بليزر & \multirow{3}{*}{ 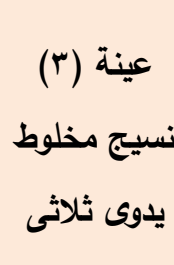 } \\
\hline 5 & 86.67 & 4.00 & 52.00 & تصميم (Y I ) بنطلون أسبور وسويت شيرت & \\
\hline 4 & 89.67 & 0.84 & 53.80 & تصميم (ب ا ) فستان كلاسيك & \\
\hline
\end{tabular}




\begin{tabular}{|c|c|c|c|c|c|}
\hline 3 & 90.00 & 1.00 & 54.00 & تصميم (؛ ا ) تيشيرت وجونلة & الأبعاد منتظم \\
\hline 2 & 92.67 & 0.55 & 55.60 & تصميم (ه 1) عباءة خارجية & \\
\hline
\end{tabular}

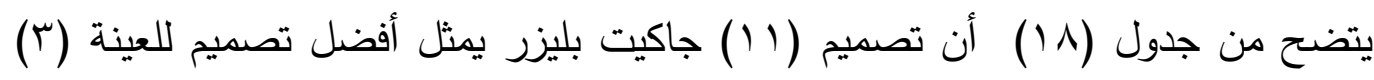

نسيج مخلوط يدوى ثلاثى الأبعاد منتظم في تحقيق جانب الخداع البصرى بمعامل جودة ؛9\%، بينما أقل تصميم هو رقم (• (1) لعباءة خارجية لعينة (Y) نسيج ستان يدوى ثلاثى الأبعاد منتظم في تحقيق جانب الخداع البصرى، وفى ضوء ماسبق يمكن القول بأن توجد فروق ذات دلالة

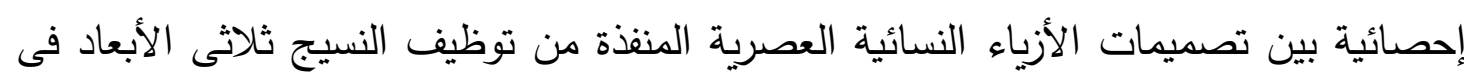
تحقيق (جانب الخداع البصرى) وفقا لأراء المتخصصين حيث وجد أن تصميم رقم (ع (10،11)

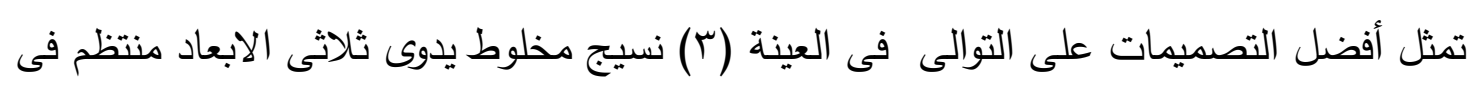

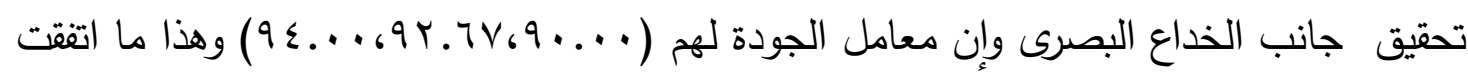

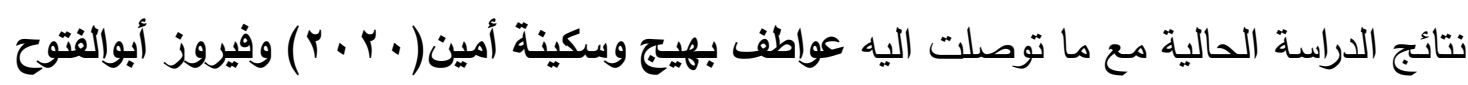

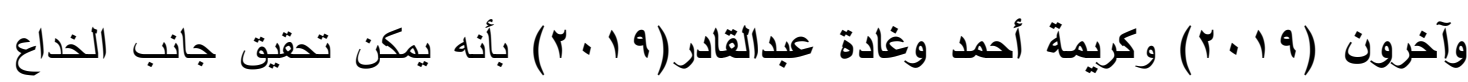
البصرى من خلال توظيف النسيج اليدوى على الملابس الخارجية للسيدات. ثانياً- الجانب الوظيفى والجمالمى والتصميمى: تم حساب مجموع تقييمات المتخصصين من أساتذة التخصص في مجال الملابس والنسيج لتصميمات الملابس الخارجية للسيدات المنفذة من توظيف النسيج ثلاثي الأبعاد وذللك في تحقيق الجانب الوظيفى والجمالى والتصميمى كما هو موضح بالجدول(9 (1) التالي:

جدول (9 19) تقييمات المتخصصين المتخصصين لامكانية توظيف الذاع البصرى النسجى على النى

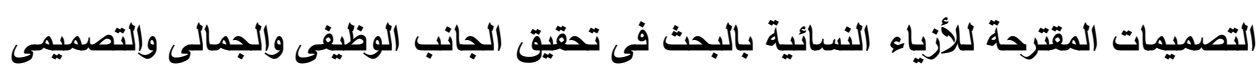




\begin{tabular}{|c|c|c|c|c|c|c|c|c|c|c|c|c|c|c|c|}
\hline \multicolumn{5}{|c|}{ نسيج مخلو طبدوى ثلاثي الأبعاد منتظل } & \multicolumn{5}{|c|}{ نسبج ستان يدوى ثلاثى الأبعاد منتظل } & \multicolumn{5}{|c|}{ نسبج تريكو يدوى ثلثاثى الأبعاد غير منتظف } & \multirow{3}{*}{ المؤشر } \\
\hline تصميم) & تصميم & تصميج & تصميم & تصميم & تصميج & تصميم & تصميم & تصميم & تصميم & تصميخ & تصميم & تصميمٍ & تصميم & تصميم & \\
\hline عباءة & وتيشينلة & فستان & وسبويت & جاكيت & عباءة & تيشيُنةت & فستان & شيروتيت & جاكيت & عباءة & تبشيبرتة & فستان & شبيروتي & جاكيت & \\
\hline 56 & 54 & 55 & 55 & 57 & 48 & 46 & 45 & 45 & 48 & 50 & 52 & 51 & 50 & 52 & 1 \\
\hline 55 & 55 & 45 & 53 & 57 & 46 & 47 & 47 & 48 & 46 & 49 & 50 & 50 & 49 & 49 & 2 \\
\hline 56 & 55 & 53 & 55 & 57 & 47 & 47 & 47 & 47 & 47 & 51 & 49 & 52 & 51 & 51 & 3 \\
\hline 56 & 54 & 54 & 53 & 56 & 50 & 45 & 48 & 48 & 50 & 50 & 52 & 49 & 50 & 50 & 4 \\
\hline 56 & 53 & 45 & 45 & 57 & 46 & 48 & 48 & 48 & 46 & 52 & 51 & 50 & 52 & 52 & 5 \\
\hline
\end{tabular}

حساب تحليل التباين لمتوسط تقييم تصميمات الأزياء النسائية المنفذة من توظيف

النسيج ثلاثي الأبعاد وذلك في تحقيق الجانب الوظيفى والجمالى والتصميمى وفقا لآراء

$$
\text { المتخصصين وجدول (·r) يوضح ذلك: }
$$

جدول(· • (Y) تحليل التباين لمتوسط تقييم تصميمات الأزياء النسائية المنفذة من توظيف النسيج

ثلاثي الأبعاد في تحقيق الجانب الوظيفى والجمالى والتصميمى وفقا لآراء المتخصصين

\begin{tabular}{|c|c|c|c|c|c|}
\hline الدلالة & قيمة "ف" & المربعات & الحرجة & المربعات & مصدر التباين \\
\hline \multirow{3}{*}{.000} & \multirow{3}{*}{12.587} & 50.766 & 14 & 710.720 & بين المجموعات \\
\hline & & 4.033 & 60 & 242.000 & داخل المجموعات \\
\hline & & & 74 & 952.720 & الكلي \\
\hline
\end{tabular}

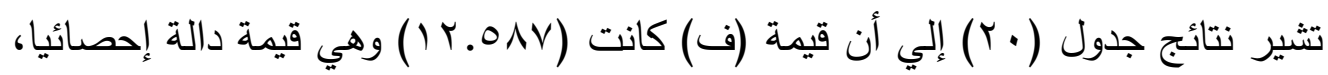

مما يدل علي وجود فروق بين تصميمات الأزياء النسائية المنفذة من توظيف النسيج ثلاثي الأبعاد في تحقيق الجانب الوظيفى والجمالى والتصميمى وفقا لآراء المتخصصين. جدول(Y ) المتوسطات ومعامل الجودة لتقييم المتخصصين لتصميمات الأزياء النسائية المنفذة من توظيف النسيج ثلاثي الأبعاد في تحقيق الجانب الوظيفى والجمالى والتصميمى

\begin{tabular}{|c|c|c|c|c|c|}
\hline ترتيب & معامل & الانحراف & المتوسط & تصميمات الملابس الخارجية للسيدات & \\
\hline 5 & 84.67 & 1.14 & 50.80 & تصميم (1) جاكيت بليزر & \multirow{3}{*}{ نسيج نية (1) } \\
\hline 6 & 84.00 & 0.84 & 50.40 & تصميم (r) بنطلون أسبور وسويت شيرت & \\
\hline 6 & 84.00 & 0.71 & 50.40 & تصميم (ץ) فستان كلاسيك & \\
\hline
\end{tabular}




\begin{tabular}{|c|c|c|c|c|c|}
\hline 5 & 84.67 & 0.84 & 50.80 & تصميم (؛) تيشيرت وجونلة & \multirow{2}{*}{ منتظم الأبعاد غير } \\
\hline 6 & 84.00 & 0.84 & 50.40 & تصميم (•) عباءة خارجية & \\
\hline 7 & 79.00 & 2.49 & 47.40 & تصميم (آ) جاكيت بليزر & \multirow{5}{*}{ يديج الأبعاد ثلاثى ستان } \\
\hline 8 & 78.67 & 1.00 & 47.20 & تصميم (V) بنطلون أسبور وسويت شيرت & \\
\hline 9 & 78.33 & 1.00 & 47.00 & تصميم (^) فستان كلاسيك & \\
\hline 10 & 77.67 & 1.14 & 46.60 & تصميم (9) تيشيرت وجونلة & \\
\hline 7 & 79.00 & 1.67 & 47.40 & تصميم (• 1) عباءة خارجية & \\
\hline 1 & 94.67 & 0.45 & 56.80 & تصميم (1 ') جاكيت بليزر & \multirow{5}{*}{ 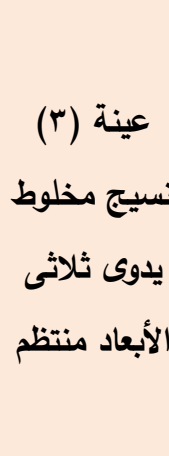 } \\
\hline 4 & 87.00 & 4.15 & 52.20 & تصميم (r I T) بنظلون أسبور وسويت شيرت & \\
\hline 6 & 84.00 & 4.98 & 50.40 & تصميم (ז ا ) فستان كلاسيك & \\
\hline 3 & 90.33 & 0.84 & 54.20 & تصميم (ع ا ) تيشيرت وجونلة & \\
\hline 2 & 93.00 & 0.45 & 55.80 & تصميم (ه 1 ) عباءة خارجية & \\
\hline
\end{tabular}

تبين من جدول (Yl) أن تصميم (II) جاكيت بليزر يمثل أفضل تصميم في عينة

(r) نسيج مخلوط يدوى ثلاثى الأبعاد منتظم في تحقيق الجانب الوظيفى والجمالى والتصميمى. وتصميم (9) تيشيرت وجونلة يمثل أقل تصميم في عينة (Y) نسيج ستان يدوى ثلاثى الأبعاد منتظم في تحقيق الجانب الوظيفى والجمالى والتصميدى. وفى ضوء ماسبق يمكن القول بأن توجد فروق ذات دلالة إحصائية بين تصميمات الأزياء النسائية العصرية المنفذة من توظيف النسيج ثلاثى الأبعاد فى تحقيق (جانب الوظيفى والجمالى والتصميمى) وفقا لأراء المتخصصين

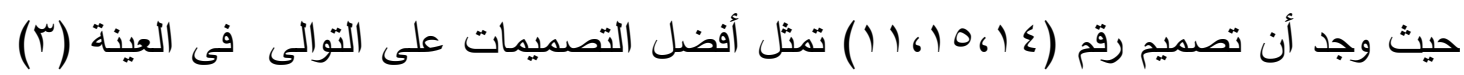
نسيج مخلوط يدوى ثلاثى الابعاد منتظم فى تحقيق جانب الخداع البصرى وإن معامل الجودة

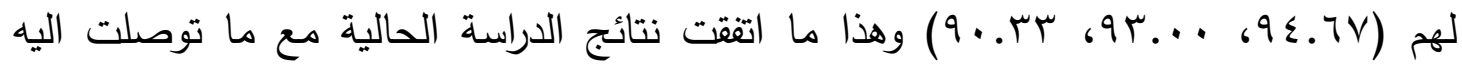
نرمين حمدى وعواطف بهيج(1/ + ب) بأنه يمكن توظيف النسيج ثلاثى الأبعاد فى تحقيق (جانب الوظيفى والجمالى والتصميمى) على الأزياء النسائية العصرية. ثالثاً-ـ الجاتب التسويقى والإقتصادى: حساب مجموع تقييمات المتخصصين من أساتذة التخصص في مجال الملابس والنسيج لتصميمات الأزياء النسائية المنفذة من توظيف النسيج 
ثلاثي الأبعاد وذللك في تحقيق الجانب التسويقى والإقتصادى كما هو موضح بالجدول(r)

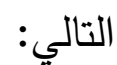

جدول (r) تقييمات المتخصصين لتصميمات الأزياء النسائية المنفذة من توظيف النسيج ثلاثي الأبعاد في تحقيق الجانب التسويقى والإقتصادى لئى الإباء

\begin{tabular}{|c|c|c|c|c|c|c|c|c|c|c|c|c|c|c|c|}
\hline \multicolumn{5}{|c|}{ نسيج مخلوط يدوى ثلاثى الأبعاد منتظم } & \multicolumn{5}{|c|}{ نسيج ستان بلوى ثلاثي الأبعاد منتظد } & \multicolumn{5}{|c|}{ نسيج تريكو بدوى ثلاثى الأبعاد غبر منتظد } & \multirow{3}{*}{ المؤشر } \\
\hline تصنيم & تصميم & تصمي & تصميم & تصميم & تصميم & تصنميم & تصميح & تصميم & تصميم) & تصميم & تصميم & تصميم & تصميم & تصميح & \\
\hline عباءة & تيُشيرية & فستان & شبويتٍ & جاكيت & عباءة & تيشبيرتة & فستان & 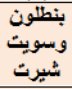 & جاكيت & عباءة & وتشئلةت & فستان & شوبنويت & جاكيت & \\
\hline 55 & 54 & 55 & 53 & 56 & 47 & 45 & 47 & 47 & 47 & 51 & 50 & 53 & 51 & 51 & 1 \\
\hline 56 & 55 & 53 & 54 & 57 & 49 & 48 & 46 & 46 & 49 & 51 & 51 & 49 & 51 & 49 & 2 \\
\hline 55 & 53 & 45 & 54 & 56 & 48 & 47 & 46 & 47 & 48 & 50 & 49 & 50 & 50 & 50 & 3 \\
\hline 56 & 54 & 55 & 53 & 57 & 47 & 46 & 48 & 48 & 47 & 51 & 51 & 51 & 51 & 51 & 4 \\
\hline 56 & 54 & 53 & 55 & 57 & 48 & 48 & 47 & 47 & 48 & 52 & 51 & 52 & 52 & 52 & 5 \\
\hline
\end{tabular}

تم حساب تحليل التباين لمتوسط تقييم تصميمات الأزياء النسائية المنفذة من توظيف النسيج ثلاثي الأبعاد وذلك في تحقيق الجانب التسويقى والإقتصادى وفقا لآراء المتخصصين

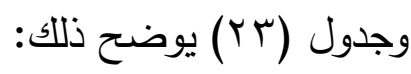

جدول(T) تحليل التباين لمتوسط تقييم تصميمات الأزياء النسائية المنفذة من توظيف النسيج ثلاثي الأبعاد في تحقيق الجانب التسويقى والإقتصادى وفقا لآراء المتخصصين

\begin{tabular}{|c|c|c|c|c|c|}
\hline الدلالة & قيمة "ف" & المربعات & الحرية & مجموع المربعات & مصدر التباين \\
\hline \multirow{3}{*}{.000} & \multirow{3}{*}{26.439} & 50.939 & 14 & 713.147 & بين المجموعات \\
\hline & & 1.927 & 60 & 115.600 & داخل المجموعات \\
\hline & & & 74 & 828.747 & الكلي \\
\hline
\end{tabular}

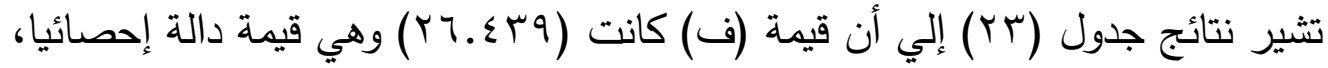

مما يدل علي وجود فروق بين تصميمات الأزياء النسائية المنفذة من توظيف النسيج ثلاثي الأبعاد في تحقيق الجانب التسويقى والإقتصادى وفقا لآراء المتخصصين.

جدول(Y) المتوسطات ومعامل الجودة لتقييم المتخصصين لتصميمات الأزياء النسائية المنفذة من توظيف النسيج ثلاثي الأبعاد في تحقيق الجانب التسويقى والإقتصادى 
مجلة دراسات وبحوث التربية النوعية

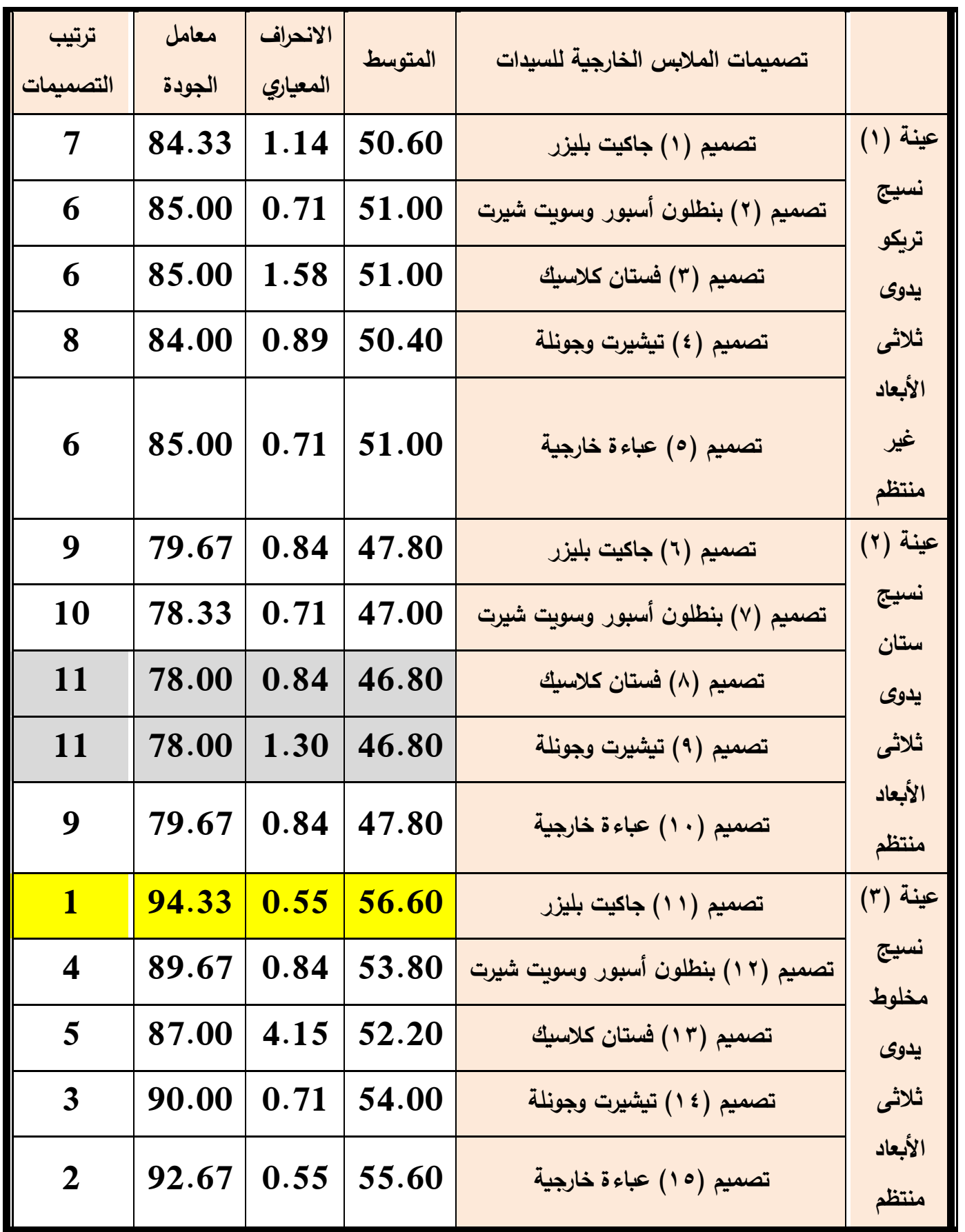

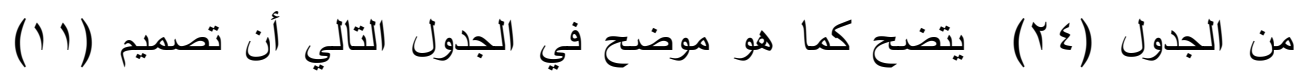
جاكيت بليزر يمثل أفضل تصميم في عينة (ץ) نسيج مخلوط يدوى ثلاثى الأبعاد منتظم في هي تحقيق الجانب التسويقى والإقتصادى، وتصميم (9) تيشيرت وجونلة، تصميم (^) فستان كلاسيك يمثل أقل تصميم في عينة (r) نسيج ستان يدوى ثلاثى الأبعاد منتظم في تحقيق التسويقى

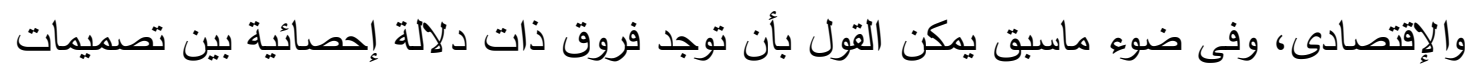
الأزياء النسائية العصرية المنفذة من توظيف النسيج ثلاثى الأبعاد فى تحقيق (جانب التسويقى

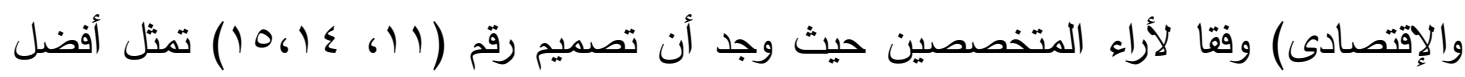


التصميمات على التوالى فى العينة (r) نسيج مخلوط يدوى ثلاثى الابعاد منتظم فى تحقيق

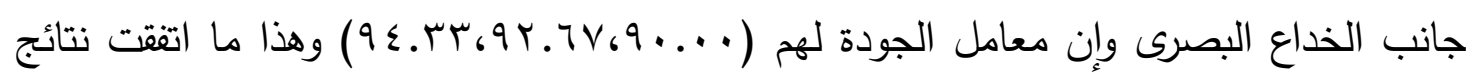

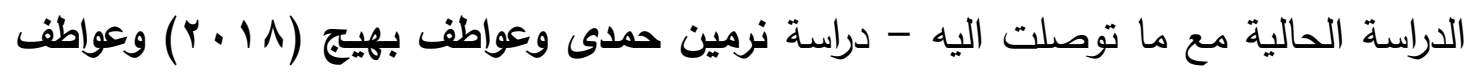

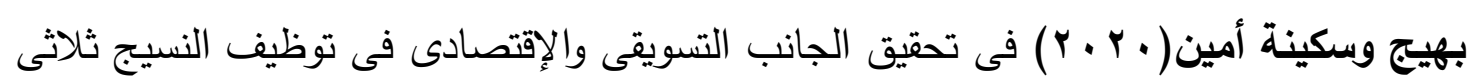
الأبعاد على الأزياء النسائية العصرية. رلبعاً- جواتب التقييم (ككل): تم حساب تحليل التباين لمتوسط تقييم تصميمات الملابس الخارجية للسيدات المنفذة من توظيف النسيج ثلاثي الأبعاد وذلك في تحقيق جوانب التقييم (ككل) وفقا لآراء المتخصصين وجدول (ro) يوضح ذللك:

جدول(ro ) تحليل التباين لمتوسط تقييم تصميمات الأزياء النسائية المنفذة من توظيف النسيج ثلاثي الأبعاد في تحقيق جوانب التقييم (ككل) وفقا لآراء المتخصصين

\begin{tabular}{|c|c|c|c|c|c|}
\hline الالالة & قيمة "ت" & متوسط & الحرجة & مجموع المربعات & مصدر التباين \\
\hline \multirow{3}{*}{.000} & \multirow{3}{*}{58.058} & 162.084 & 14 & 2269.173 & بين المجموعات \\
\hline & & 2.792 & 210 & 586.267 & داخل المجموعات \\
\hline & & & 224 & 2855.440 & الكلي \\
\hline
\end{tabular}

تشير نتائج جدول (Y0) إلي أن قيمة (ف) كانت (01.01) وهي قيمة دالة إحصائيا، مما يدل علي وجود فروق بين تصميمات الملابس الخارجية للسيدات المنفذة من توظيف النسيج ثلاثي الأبعاد في تحقيق جوانب التقييم (ككل) وفقا لآراء المتخصصين. جدول(Y Y) المتوسطات ومعامل الجودة لتقييم المتخصصين لتصميمات الأزياء النسائية المنفذة من توظيف النسيج ثلاثي الأبعاد في تحقيق جوانب التقييم (ككل)

\begin{tabular}{|c|c|c|c|c|c|}
\hline التصميمات & الجودة & الانعراف & المتوسط & تصميمات الملابس الخارجية للسيدات & \\
\hline 8 & 84.44 & 1.11 & 50.67 & تصميم (1) جاكيت بليزر & \multirow{4}{*}{ عينة } \\
\hline 6 & 84.78 & 0.92 & 50.87 & تصميم (ץ) بنطلون أسبور وسويت شيرت & \\
\hline 9 & 84.11 & 1.19 & 50.47 & تصميم (ץ) فستان كلاسيك & \\
\hline 10 & 83.89 & 1.05 & 50.33 & تصميم (؛) تيشيرت وجونلة & \\
\hline
\end{tabular}

المجلد الثامن- العدد الأول- مسلسل العدد (15)- يناير 2022- الجزء الأول 


\begin{tabular}{|c|c|c|c|c|c|}
\hline 7 & 84.56 & 0.88 & 50.73 & تصميم (•) عباءة خارجية & |لأبعاد \\
\hline 11 & 78.33 & 1.89 & 47.00 & تصميم (؟) جاكيت بليزر & \multirow{2}{*}{ نسينة } \\
\hline 13 & 77.89 & 1.10 & 46.73 & تصميم (V) بنظلون أسبور وسويت شيرت & \\
\hline 14 & 77.67 & 1.06 & 46.60 & تصميم (^) فستان كلاسيك & \multirow{2}{*}{ سيتان } \\
\hline 12 & 78.11 & 1.06 & 46.87 & تصميم (9) تيشيرت وجونلة & \\
\hline 11 & 78.33 & 1.89 & 47.00 & تصميم ( · 1) عباءة خارجية & منتظم \\
\hline 1 & 94.33 & 0.63 & 56.60 & تصميم (1') جاكيت بليزر & \multirow{2}{*}{ عينة } \\
\hline 4 & 87.78 & 3.22 & 52.67 & تصميم (r I) بنطلون أسبور وسويت شيرت & \\
\hline 5 & 86.89 & 3.78 & 52.13 & تصميم ( ب ا ) فستان كلاسيك & 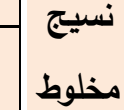 \\
\hline 3 & 90.11 & 0.80 & 54.07 & تصميم (؛ 1) تيثيرت وجونلة & 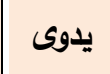 \\
\hline 2 & 92.78 & 0.49 & 55.67 & تصميم (ه 1 ) عباءة خارجية & منتظم الأبعاد \\
\hline
\end{tabular}

يتبين من جدول (YT) أن تصميم (1) جاكيت بليزر يمثل أفضل تصميم في عينة

(r) نسيج مخلوط يدوى ثلاثى الأبعاد منتظم في تحقيق جوانب التقييم (ككل). وتصميم (^) فستان كلاسيك يمثل أقل تصميم في عينة (r) نسيج ستان يدوى ثلاثى الأبعاد منتظم في تحقيق جوانب التقييم (ككل). وفى ضوء ماسبق يمكن القول بأن توجد فروق ذات دلالة إحصائية بين

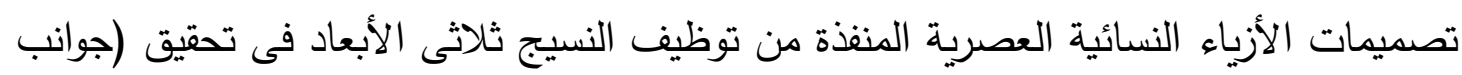
التقييم ككل) وفقا لأراء المتخصصين حيث وجد أن تصميم رقم (11، ؛ (10،1) تمثل أفضل التصميمات على التوالى فى العينة (r) نسيج مخلوط يدوى ثلاثى الابعاد منتظم فى تحقيق

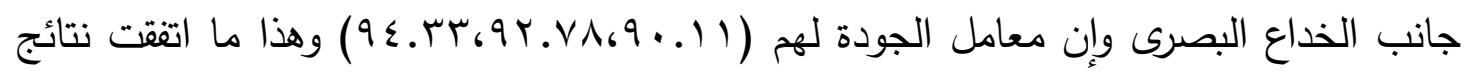
الدراسة الحالية مع ما توصلت اليه نرمين حدى وعواطف بهيج(1/ • ب) وعواطف بهيج، 


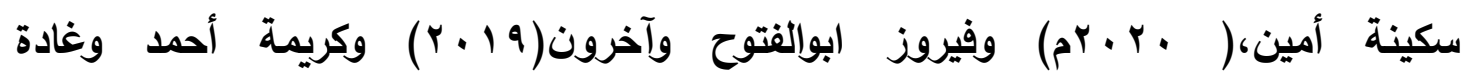
عبدالقادر(9 1 • r) فى تحقيق جانب الخداع البصرى وتحقيق الجوانب الجمالية والوظيفية من خلال توظيف النسيج اليدوى ثلاثى الأبعاد على الأزياء النسائية العصرية. خامساً- محاور جوانب التقييم (ككل): تم حساب تحليل التباين لمتوسط محاور تقييم تصميمات الملابس الخارجية للسيدات المنفذة من توظيف النسيج ثلاثي الأبعاد وفقاً لأراء المتخصصين وجدول (YV) يوضح ذلك:

جدول(rV) تحليل التباين لمتوسط محاور تقييم تصميمات الأزياء النسائية المنفذة من توظيف النسيج ثلاثي الأبعاد

\begin{tabular}{|c|c|c|c|c|c|}
\hline الدلاية & قيمة & متوسط المربعات & الحرية & مجموع المربعات & مصدر التباين \\
\hline \multirow{3}{*}{.696} & \multirow{3}{*}{.363} & 4.653 & 2 & 9.307 & بين المجموعات \\
\hline & & 12.820 & 222 & 2846.133 & لداخل المجموعات \\
\hline & & & 224 & 2855.440 & الكلي \\
\hline
\end{tabular}

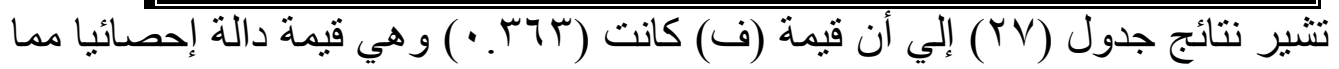

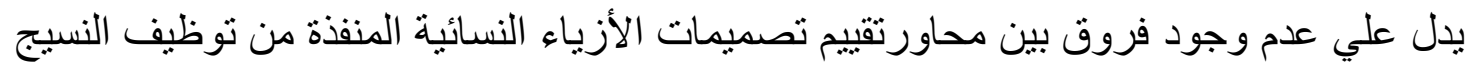

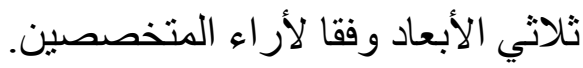
جدول(Y^) المتوسطات ومعامل الجودة لمحاور تصميمات الأزياء النسائية المنفذة من توظيف النسيج ثلاثي الأبعاد

\begin{tabular}{|c|c|c|c|c|}
\hline ترتيب المحاور & معامل & الانحراف & المتوسط & 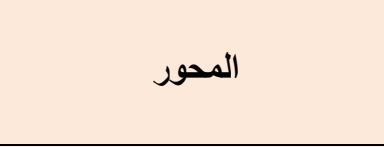 \\
\hline 3 & 83.89 & 3.79 & 50.33 & جانب الذداع البصرى \\
\hline 2 & 84.20 & 3.59 & 50.52 & الجانب الوظيفى والجمالى \\
\hline 1 & 84.71 & 3.35 & 50.83 & الجانب التسويقى والإقتصادى \\
\hline
\end{tabular}

تبين من جدول (r^) أن المحور الثالث " الجانب التسويقى والإقتصادى " يمثل أفضل المحاور في ضوء آراء المتخصصين، يليه المحور الثاني " الجانب الوظيفى والجمالى والتصميمى "، يليه المحور الأول: جانب الخداع البصرى، ويأتي في المرتبة الأخيرة ويمكن 
ترتيب تصميمات الأزياء النسائية المنفذة من توظيف النسيج ثلاثي الأبعاد وفقا لآراء المتخصصين في ضوء محاور التقييم كما بجدول (9) التالى:

جدول(؟ ץ ) ترتيب تصميمات الأزياء النسائية المنفذة من توظيف النسيج ثلاثي الأبعاد

\begin{tabular}{|c|c|c|c|c|c|c|}
\hline النصميمات & النقيسم & والجانب التسبقيقى & والجمالجى والتصميمى الوظيفى & الخداع البصرى & تصميمات الثمالسى النخارجية لنسيـات & \\
\hline 1 & 94.33 & 94.33 & 94.67 & 94 & تصميج (1, (1) جاكيت بلبزر & \multirow{5}{*}{ 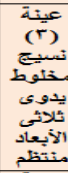 } \\
\hline 2 & 92.78 & 92.67 & 93 & 92.67 & تصميج (0 10) عباءة خارجية & \\
\hline 3 & 90.11 & 90 & 90.33 & 90 & تصميج (؛ 1) تيشيرت وجونلة & \\
\hline 4 & 87.78 & 89.67 & 87 & 86.67 & تصميج (r ( ) بنطلون أسبور وسويت شيرت & \\
\hline 5 & 86.89 & 87 & 84 & 89.67 & تصميم (r I) فستان كلاسيك & \\
\hline 6 & 84.78 & 85 & 84 & 85.33 & تصميت (r) بذطلون أسبور وسويت شيرت & \multirow{5}{*}{ 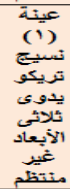 } \\
\hline 7 & 84.56 & 85 & 84 & $\mathbf{8 4 . 6 7}$ & تصميج (0) عباءوذ خارجية & \\
\hline 8 & 84.44 & 84.33 & 84.67 & 84.33 & تصميت ( ') جاكيت بليزر & \\
\hline 9 & 84.11 & 85 & 84 & 83.33 & تصميج (r) فستات كلاسيك & \\
\hline 10 & 83.89 & 84 & $\mathbf{8 4 . 6 7}$ & 83 & تصميح (؛) تيشيرت وجونتة & \\
\hline 11 & 78.33 & 79.67 & 79 & 76.33 & تصميح ( ( ) جاكيت بليزر & \multirow{5}{*}{ ريناتي } \\
\hline 11 & 78.33 & 79.67 & 79 & 76.33 & تصميج ( · (1) عباءةً خارجية & \\
\hline 12 & 78.11 & 78 & 77.67 & 78.67 & تصميم (9) تيشيرت وجونثة & \\
\hline 13 & 77.89 & 78.33 & 78.67 & 76.67 & تصميت (v) بنطوت أسبور وسويت شيرت & \\
\hline 14 & 77.67 & 78 & 78.33 & 76.67 & تصميم (^) فستان كلاسيك & \\
\hline
\end{tabular}

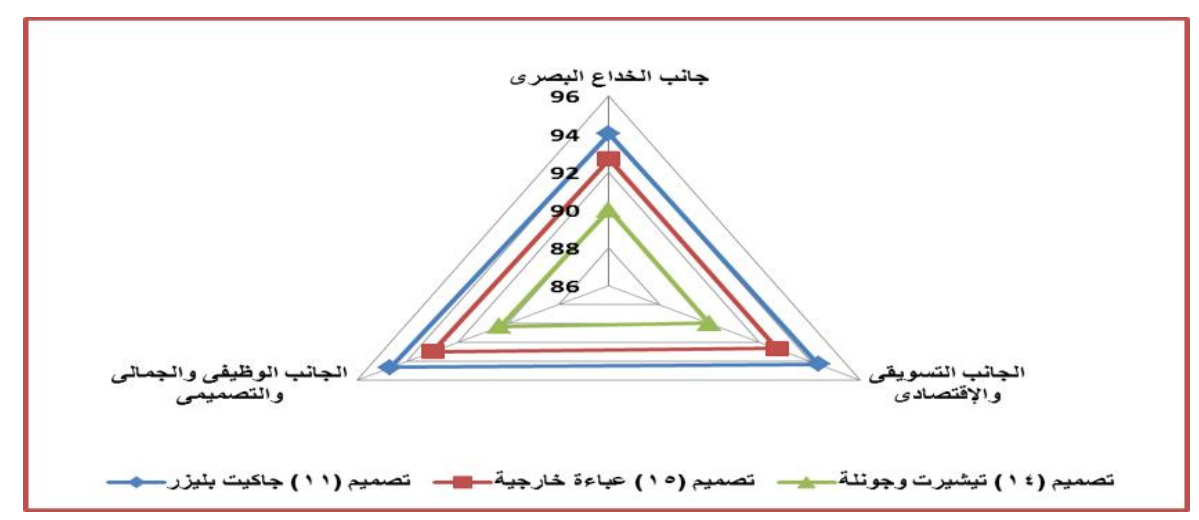

شكل (1) أفضل ثلاث تصميمات الأزياء النسائية المنفذة من توظيف النسيج ثلاثي الأبعاد

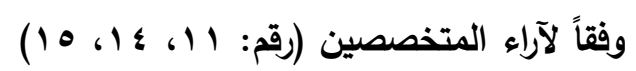

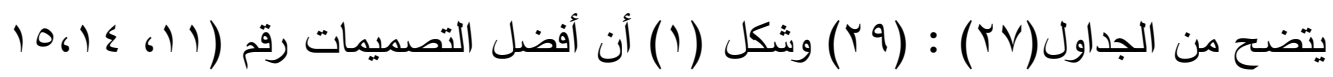

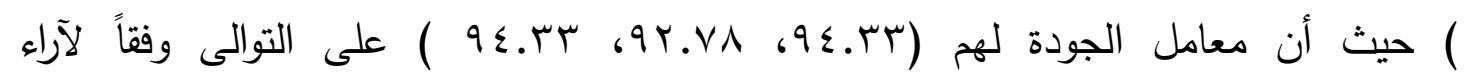

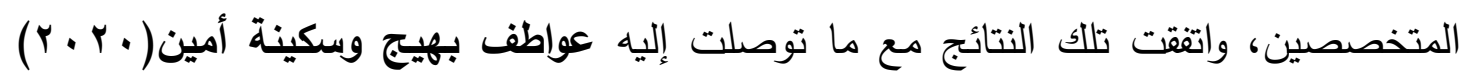

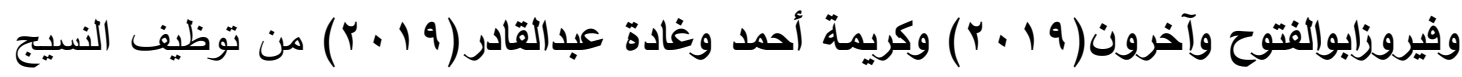
ثلاثي الأبعاد فى تحقيق (جانب الخداع البصرى، الجانب الوظيفى والجمالى والتصميمى، الجانب التسويقى والإقتصادى) على الأزياء النسائية العصرية، وفي ضوء ما سبق يمكن قبول الفرض الأول للبحث والأي ينص علي: توجد فروق ذات دلالة إحصائية وفقاً لأراء 
المتخصصين بين امكانية توظيف الخداع البصرى النسجى على التصميمات المقترحة للأزياء النسائية بالبحث فى تحقيق جوانب التقييم،

الفرض الثانى: توجد فروق ذات دلالة إحصائية وفقاً لأراء المستهلكات بين امكانية توظيف الذاع البصرى النسجى على التصميمات المقترحة للأزياء النسائية بالبحث فى تحقيق بنود

تم حساب مجموع تتييمات المستهلكات عددهم(•؟) لتصميمات الأزياء النسائية المنفذة

من توظيف النسيج ثلاثي الأبعاد وذللك في تحقيق بنود التقييم (ككل) هو موضح بالجدول (·r)

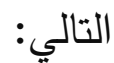

جدول (·r) تقييمات المستهلكات لتصميمات الأزياء النسائية المنفذة من توظيف النسيج

ثلاثي الأبعاد في تحقيق بنود التقييم (ككل)

\begin{tabular}{|c|c|c|c|c|c|c|c|c|c|c|c|c|c|c|c|}
\hline \multicolumn{5}{|c|}{ 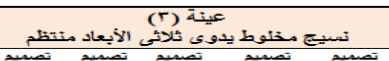 } & \multicolumn{5}{|c|}{ 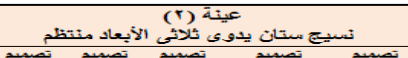 } & \multicolumn{5}{|c|}{ 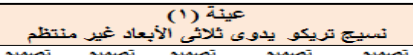 } & \multirow{3}{*}{ المقئشر } \\
\hline تصنمب (1) & $(1 \pm)$ & تصنn & تصنم) & تصنم) & تصنn & $a^{(a)}$ & تصنم) & (v) & تصنم) & تصنيم & تصمبn & (T) & تصم) & تص⿴囗十) & \\
\hline عياءت & تيشتئلة & قستستان & رئتويت & جاكيت & عياءة & تيويتيدة & قستات & ريستويت & جاكيت & $\bar{s} \leqslant \leq$ & تيخيخديرة & قستات & 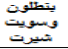 & حاكيت & \\
\hline 116 & 116 & 117 & 115 & 118 & 110 & 109 & 110 & 111 & 109 & 112 & 114 & 113 & 114 & 112 & 1 \\
\hline 116 & 115 & 116 & 117 & 117 & 111 & 111 & 110 & 109 & 111 & 114 & 113 & 112 & 112 & 114 & 2 \\
\hline 115 & 115 & 115 & 116 & 118 & 111 & 110 & 111 & 111 & 111 & 113 & 113 & 114 & 113 & 114 & 3 \\
\hline 116 & 117 & 116 & 116 & 118 & 110 & 110 & 110 & 109 & 110 & 112 & 112 & 114 & 113 & 112 & 4 \\
\hline 115 & 116 & 115 & 117 & 116 & 109 & 111 & 109 & 110 & 109 & 114 & 114 & 112 & 112 & 112 & 5 \\
\hline 116 & 115 & 117 & 115 & 118 & 111 & 110 & 111 & 111 & 111 & 113 & 114 & 114 & 112 & 113 & 6 \\
\hline 116 & 117 & 115 & 116 & 118 & 111 & 110 & 111 & 109 & 110 & 114 & 113 & 113 & 114 & 114 & 7 \\
\hline 115 & 116 & 115 & 117 & 117 & 109 & 109 & 109 & 111 & 109 & 112 & 112 & 112 & 113 & 113 & 8 \\
\hline 116 & 116 & 116 & 115 & 118 & 109 & 110 & 110 & 110 & 109 & 113 & 114 & 114 & 114 & 113 & 9 \\
\hline 116 & 116 & 117 & 115 & 116 & 110 & 110 & 111 & 109 & 110 & 114 & 114 & 113 & 112 & 114 & 10 \\
\hline 114 & 115 & 116 & 116 & 118 & 111 & 109 & 111 & 109 & 111 & 114 & 113 & 113 & 112 & 114 & 11 \\
\hline 116 & 117 & 116 & 115 & 117 & 110 & 111 & 110 & 111 & 110 & 113 & 113 & 112 & 114 & 113 & 12 \\
\hline 115 & 116 & 117 & 116 & 118 & 110 & 110 & 109 & 111 & 109 & 112 & 112 & 114 & 112 & 112 & 13 \\
\hline 116 & 116 & 116 & 115 & 117 & 109 & 111 & 109 & 110 & 109 & 112 & 114 & 112 & 113 & 112 & 14 \\
\hline 116 & 115 & 116 & 115 & 118 & 111 & 110 & 111 & 110 & 111 & 114 & 113 & 114 & 112 & 114 & 15 \\
\hline
\end{tabular}

وتم حساب تحليل التباين لمتوسط تقييم تصميمات الأزياء النسائية المنفذة من توظيف

النسيج ثلاثي الأبعاد وذلك في تحقيق بنود التقييم (ككل) وفقا لآراء المستهلكات كما موضح

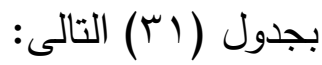

جدول( آس) تحليل التباين لمتوسط تقييم تصميمات الأزياء النسائية المنفذة من توظيف النسيج الأبعاد وذلك في تحقيق بنود التقييم (ككل) وفقا لآراء المستهلكات

\begin{tabular}{|c|c|c|c|c|c|}
\hline الالالة & قيمة "ف" & متوسط & درجة & مجموع المربعات & مصدر التباين \\
\hline
\end{tabular}




\begin{tabular}{|c|c|c|c|c|c|}
\hline & & المربعات & الحرية & & \\
\hline \multirow{3}{*}{.000} & \multirow{3}{*}{154.137} & 101.192 & 14 & 1416.693 & بين المجموعات \\
\hline & & .657 & 210 & 137.867 & داخل المجموعات \\
\hline & & & 224 & 1554.560 & الكلي \\
\hline
\end{tabular}

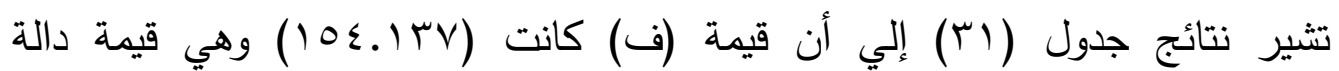
إحصائيا، مما يدل علي وجود فروق بين تصميمات الأزياء النسائية المنفذة من توظيف النسيج ثلاثي الأبعاد في تحقيق بنود التقييم (ككل) وفقا لآراء المستهلكات. جدول(Y) المتوسطات ومعامل الجودة لتقييم المستهكات لتصميمات الأزياء النسائية

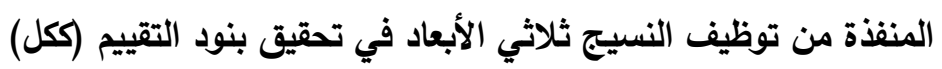

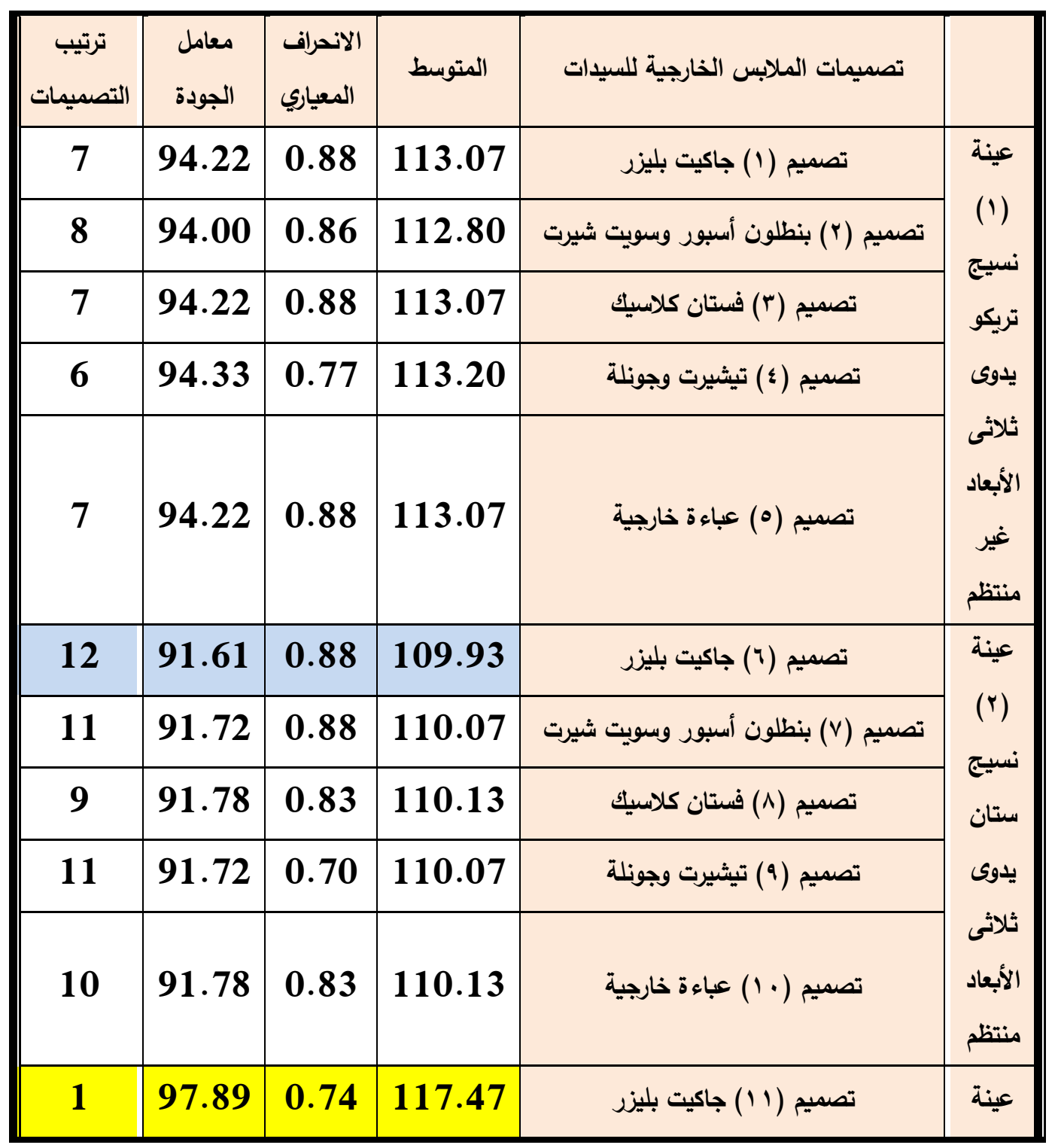




\begin{tabular}{|c|c|c|c|c|c|}
\hline 4 & 96.44 & 0.80 & 115.73 & تصميم (r Y) بنطلون أسبور وسويت شيرت & $(r)$ \\
\hline 2 & 96.67 & 0.76 & 116.00 & تصميم (r ا) فستان كلاسيك & نسيج \\
\hline 5 & 96.33 & 0.63 & 115.60 & تصميم ( ؛ () تيشيرت وجونلة & يدوى \\
\hline 3 & 96.56 & 0.74 & 115.87 & تصميم (ه 1) عباءة خارجية & منتظم \\
\hline
\end{tabular}

يتضح من جدول (Yr) أن تصميم (I') جاكيت بليزر يمثل أفضل تصميم في

عينة (r) نسيج مخلوط يدوى ثلاثى الأبعاد منتظم في تحقيق بنود التقييم (ككل)، وتصميم (؟) جاكيت بليزريمثل أقل تصميم في عينة (Y) نسيج ستان يدوى ثلاثى الأبعاد منتظم في تحقيق

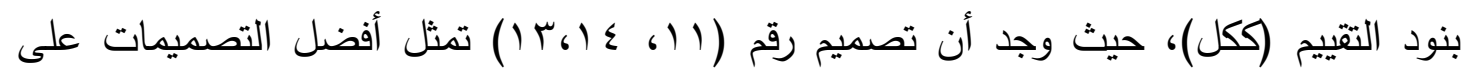
التوالى فى العينة (ب) نسيج مخلوط يدوى ثلاثى الابعاد منتظم فى تحقيق جانب الخداع

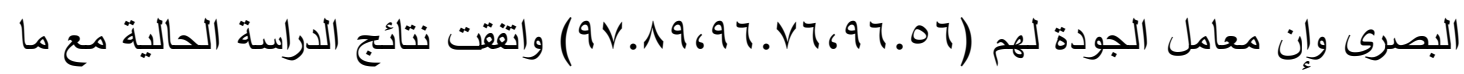

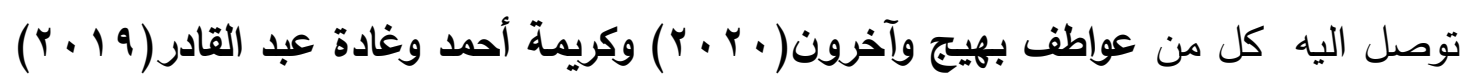

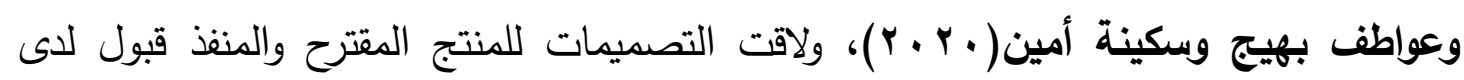
المستهلك لتماشيها مع اتجاهات الموضة ومناسبة التكلفة وتميزها بالجاذبية والتثرد عن المتاح

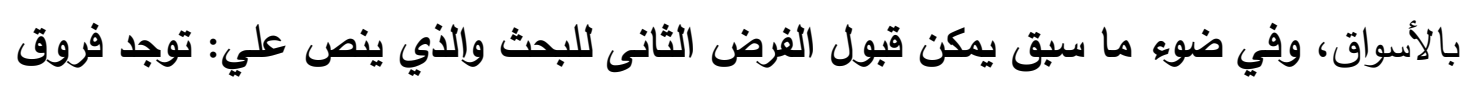
ذات دلالة إحصائية وفقاً لأراء المستهلكات بين امكانية توظيف الخداع البصرى النسجى على فئى التصميمات المقترحة للأزياء النسائية بالبحث فى تحقيق بنود التقييم.

الفرض الثالث: توجد فروق ذات دلالة إحصائية وفقاً لأراء أصحاب محلات بيع الملابس بين امكانية توظيف الذداع البصرى النسجى على التصميمات المقترحة للازياء النسائية فى تحقيق بنود التقييم. حساب مجموع تقييمات أصحاب محلات بيع الملابس عددهم (1) لتصميمات الأزياء النسائية المنفذة من توظيف النسيج ثلاثي الأبعاد وذلك في تحقيق بنود التقييم (ككل) هو موضح

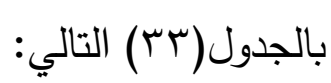

جدول (Tr) تقييمات أصحاب محلات بيع الملابس لتصميمات الأزياء النسائية المنفذة من توظيف النسيج ثلاثي الأبعاد في تحقيق بنود التقييم (ككل) 


\begin{tabular}{|c|c|c|c|c|c|c|c|c|c|c|c|c|c|c|c|}
\hline \multicolumn{5}{|c|}{ نسيج مخلوط يدوى ثلاثي الأبعاد منتظم } & \multicolumn{5}{|c|}{ نسيـ ستان يدوي ثلاثئ (T) الأبعاد منتظم } & \multicolumn{5}{|c|}{ نسيع تريكو يدوى عثلاثئ (') الأبعاد غيز منتظم } & \multirow{3}{*}{ المؤشر } \\
\hline تصميم & تصنميم) & 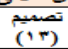 & تصميمج) & تصميمج & تصميمج & تصميم & (^) & تصميم & تصميجم & تصميم & تصميمج & تصميم & تصمين & تصميم & \\
\hline عباءة & تيجيتية & قَستان & وسيروتيت & جاكيت & عباءة & تيشيرية & قستان & شيسويتي & جاكيت & عياءة & تيشيرتة & قَستان & وسيرويت & جاكيت & \\
\hline 52 & 50 & 49 & 51 & 53 & 43 & 41 & 40 & 42 & 43 & 47 & 45 & 44 & 46 & 47 & 1 \\
\hline 51 & 49 & 50 & 49 & 53 & 43 & 41 & 40 & 43 & 42 & 46 & 47 & 44 & 45 & 46 & 2 \\
\hline 52 & 51 & 51 & 50 & 25 & 42 & 42 & 42 & 41 & 42 & 47 & 45 & 46 & 47 & 47 & 3 \\
\hline 51 & 51 & 51 & 50 & 53 & 42 & 43 & 42 & 40 & 42 & 47 & 46 & 45 & 44 & 45 & 4 \\
\hline 52 & 49 & 50 & 49 & 53 & 41 & 40 & 41 & 41 & 41 & 44 & 44 & 47 & 45 & 44 & 5 \\
\hline 52 & 50 & 50 & 49 & 53 & 43 & 41 & 43 & 42 & 40 & 44 & 45 & 46 & 47 & 44 & 6 \\
\hline 51 & 50 & 49 & 51 & 53 & 40 & 43 & 41 & 40 & 40 & 46 & 46 & 44 & 46 & 45 & 7 \\
\hline 52 & 51 & 49 & 51 & 52 & 42 & 42 & 42 & 43 & 43 & 46 & 47 & 44 & 45 & 46 & 8 \\
\hline 52 & 51 & 50 & 49 & 53 & 40 & 40 & 40 & 43 & 40 & 45 & 45 & 46 & 46 & 45 & 9 \\
\hline 51 & 49 & 51 & 50 & 52 & 42 & 40 & 40 & 41 & 42 & 47 & 47 & 46 & 47 & 47 & 10 \\
\hline 52 & 50 & 51 & 51 & 53 & 40 & 42 & 41 & 41 & 41 & 45 & 46 & 44 & 45 & 44 & 11 \\
\hline 52 & 50 & 49 & 51 & 53 & 40 & 43 & 43 & 40 & 40 & 46 & 47 & 47 & 46 & 46 & 12 \\
\hline 51 & 51 & 50 & 49 & 52 & 43 & 40 & 42 & 42 & 43 & 47 & 45 & 47 & 44 & 47 & 13 \\
\hline 52 & 49 & 49 & 49 & 53 & 41 & 42 & 41 & 42 & 43 & 44 & 44 & 46 & 45 & 44 & 14 \\
\hline 52 & 49 & 51 & 50 & 53 & 42 & 43 & 43 & 40 & 42 & 45 & 45 & 46 & 47 & 45 & 15 \\
\hline
\end{tabular}

وتم حساب تحليل التباين لمتوسط تقييم تصميمات الأزياء النسائية المنفذة من توظيف النسيج ثلاثي الأبعاد وذلك في تحقيق بنود التقييم (ككل) وفقا لآراء أصحاب محلات بيع الملابس وجدول (عب) يوضح ذلك:

جدول(§ \) تحليل التباين لمتوسط تقييم تصميمات الأزياء النسائية المنفذة من توظيف النسيج ثلاثي الأبعاد في تحقيق بنود التقييم (ككل) وفقا لآراء أصحاب محلات بيع الملابس

\begin{tabular}{|c|c|c|c|c|c|}
\hline الدالة & قيمة "ف" & متوسط المربعات & الحرية & مجموع المربعات & مصدر التباين \\
\hline \multirow{3}{*}{.000} & \multirow{3}{*}{49.167} & 220.238 & 14 & 3083.333 & بين المجموعات \\
\hline & & 4.479 & 210 & 940.667 & داخل المجموعات \\
\hline & & & 224 & 4024.000 & الكلي \\
\hline
\end{tabular}

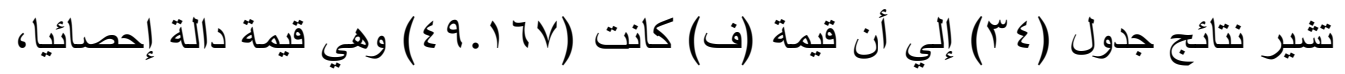
مما يدل علي وجود فروق بين تصميمات الأزياء النسائية المنفذة من توظيف النسيج ثلاثي الأبعاد في تحقيق بنود التقييم (ككل) وفقا لآراء أصحاب محلات بيع الملابس. جدول(هץ) المتوسطات ومعامل الجودة لتقييم أصحاب محلات بيع الملابس لتصميمات الأزياء النسائية من توظيف النسيج ثلاثي الأبعاد في تحقيق بنود التقييم (ككل)

\begin{tabular}{|c|c|c|c|c|c||}
\hline تصميمات الملابس الخارجية للسيدات & تلانحراف & & & \\
& & & & & \\
\hline
\end{tabular}


مجلة دراسات وبحوث التربية النوعية

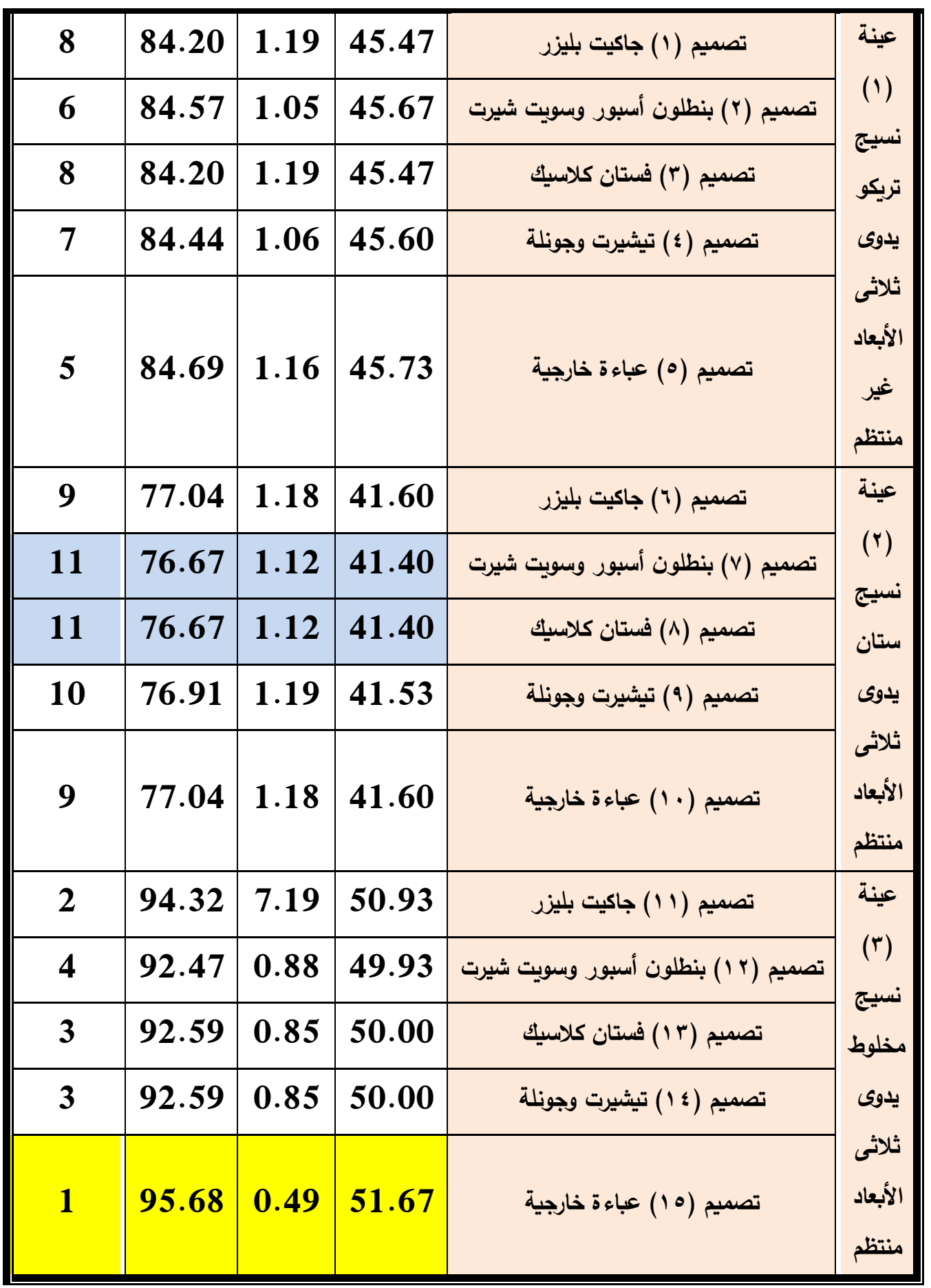

يتضح من جدول (ro) أن تصميم (10) عباءة خارجية يمثل أفضل تصميم في

عانة (r) نسيج مخلوط يدوى ثلاثى الأبعاد منتظم في تحقيق بنود التقييم (ككل)، وتصميم (V) بنطلون أسبور وسويت شيرت، تصميم (^) فستان كلاسيك يمثل أقل تصميم في عينة (؟) نسيج ستان يدوى ثلاثى الأبعاد منتظم في تحقيق بنود التقييم (ككل). حيث وجد أن تصميم رقم (10،

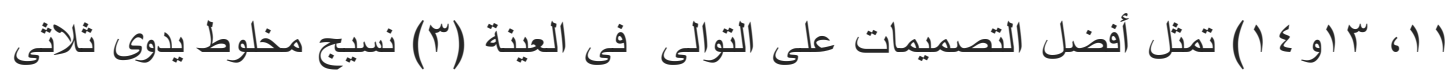


الابعاد منتظم فى تحقيق جانب الخداع البصرى وإن معامل الجودة لهم

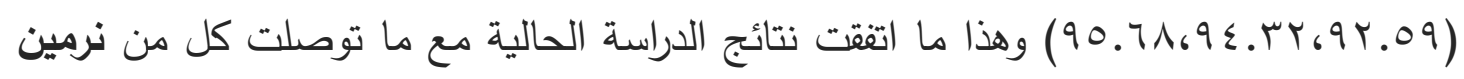

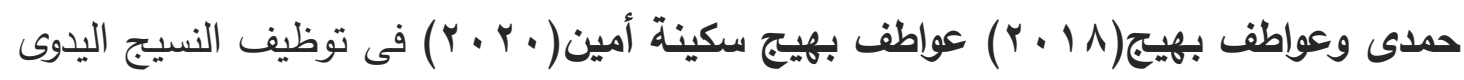

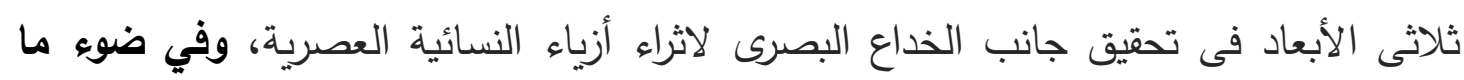
سبق يمكن قبول الفرض الثالث للبحث والذي ينص علي: توجد فروق ذات دلالة إحصائية وفقاً لأراء أصحاب محلات بيع الملابس بين امكانية توظيف الذاع البصرى النسجى على لهاب التصميمات المقترحة للأزياء النسائية فى تحقيق بنود التقييم.

الفرض الرابع: توجد علاقة إرتباطية دالة إحصائياً بين ترتيب (المتخصصين، المستهلكات، أصحاب محلات بيع الملابس) لامكانية توظيف الخداع البصرى النسجى لإثراء التصميمات المقترحة للأزياء النسائية.

تم حساب معامل ارتباط الرتب لسبيرمان بين ترتيب المتخصصين والمستهكات وأصحاب محلات بيع الملابس الأزياء النسائية المنفذة من توظيف النسيج ثلاثي الأبعاد كما هو موضح بالجدول(بr) التالي:

جدول (؟َr)ترتيب المتخصصين والمستهلكات وأصحاب محلات بيع الأزياء النسائية المنفذة من توظيف النسيج ثلاثي الأبعاد

\begin{tabular}{|c|c|c|c|c|}
\hline أصحاب محلات & المستهلكات & المتخصصين & تصميمات الملابس الخارجية للسيدات & \\
\hline 8 & 7 & 8 & تصميم ( ) جاكيت بليزر & \multirow{2}{*}{ عينة } \\
\hline 6 & 8 & 6 & تصميم (ץ) بنظلون أسبور وسويت شيرت & \\
\hline 8 & 7 & 9 & تصميم (ץ) فستان كلاسيك & تريكو \\
\hline 7 & 6 & 10 & تصميم (؛) تيشيرت وجونلة & 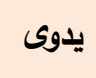 \\
\hline 5 & 7 & 7 & تصميم (ه) عباءة خارجية & غنتير \\
\hline 9 & 12 & 11 & تصميم (") جاكيت بليزر & \multirow{2}{*}{$\begin{array}{l}\text { عينة } \\
\text { (r) }\end{array}$} \\
\hline 11 & 11 & 13 & تصميم (v) بنطلون أسبور وسويت شيرت & \\
\hline
\end{tabular}

المجلد الثامن- العدد الأول- مسلسل العدد (15)- يناير 2022- الجزء الأول 
مجلة دراسات وبحوث التربية النوعية

\begin{tabular}{|c|c|c|c|c|}
\hline 11 & 9 & 14 & تصميم (^) فستان كلاسيك & \multirow{3}{*}{ شندان } \\
\hline 10 & 11 & 12 & تصميم (9) تيشيرت وجونلة & \\
\hline 9 & 10 & 11 & تصميم ( · 1) عباءة خارجية & \\
\hline 2 & 1 & 1 & تصميم (1 ') جاكيت بليزر & \multirow{2}{*}{ ع عينة } \\
\hline 4 & 4 & 4 & تصميم (r I) بنظلون أسبور وسويت شيرت & \\
\hline 3 & 2 & 5 & تصميم (ب ا ) فستان كلاسيك & نسيج \\
\hline 3 & 3 & 3 & تصميم (ء ا ) تيشيرت وجونلة & 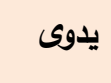 \\
\hline 1 & 5 & 2 & تصميم (0 1 ) عباءة خارجية & منتظم \\
\hline
\end{tabular}

جدول (rV) معامل ارتباط الرتب لسبيرمان بين ترتيب المتخصصين وترتيب المستهات وأصحاب محلات بيع الملابس لتصميمات الأزياء النسائية المنفذة من توظيف النسيج ثلاثي الأبعاد

\begin{tabular}{|c|c|c|c|}
\hline أصحاب محلات & المستركات & المتخصصين & \\
\hline $.970 * *$ & .857 ** & & ترتيب المتخصصين \\
\hline \multirow[t]{2}{*}{$.868^{* *}$} & & & ترتيب المستهلكات \\
\hline & & & أصحاب محلات بيع الملابس \\
\hline
\end{tabular}

جدول (^^) معامل ارتباط الرتب لسبيرمان بين ترتيب المتخصصين وترتيب المستهلكات وأصحاب محلات بيع الملابس لتصميمات الأزياء النسائية المنفذة من توظيف النسيج ثلاثي الأبعاد

\begin{tabular}{|c|c|c|c|c|}
\hline \multirow[b]{2}{*}{ الجودة الكلى معامل } & \multicolumn{3}{|c|}{ معامل الجودة } & \multirow{2}{*}{ يديج مينة (1) } \\
\hline & أصحاب محلات بيع & |المستهكات | & المتخصصين & \\
\hline$\% 90.01$ & $\%$ \%६.rT & $\% q \vee . \wedge q$ & $\% q \leq . r T$ & تصميم (1') \\
\hline
\end{tabular}

المجلد الثامن- العدد الأول- مسلسل العدد (15)- يناير 2022- الجزء الأول 


\begin{tabular}{|c|c|c|c|c|}
\hline$\% 90$ & $\% 90.71$ & $\% 97.07$ & 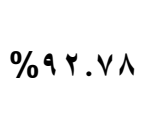 & تصباءة خارجية (ه 1) \\
\hline
\end{tabular}

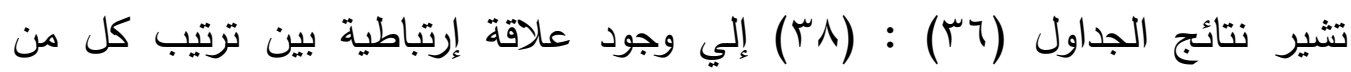
المتخصصين والمستهلكات لتصميمات الأزياء النسائية المنفذة من توظيف النسيج ثلاثي الأبعاد حيث بلغت قيمة (ر= NOV. · · ) وهي دالة إحصائيا عند مستوي دلالة (1...) وهي علاقة طردية قوية أي أن هناك توافق بين التقييم من الناحية العلمية والعملية، وجود علاقة إرتباطية

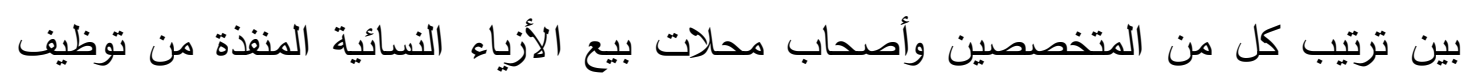
النسيج ثلاثي الأبعاد حيث بلغت قيمة (ر= •وV. . .) وهي دالة إحصائياً عند مستوي دلالة (1 (..) وهي علاقة طردية قوية أي أن هناك توافق بين التقييم من الناحية العلمية والعملية،

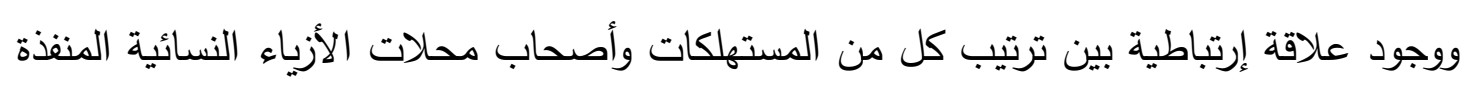

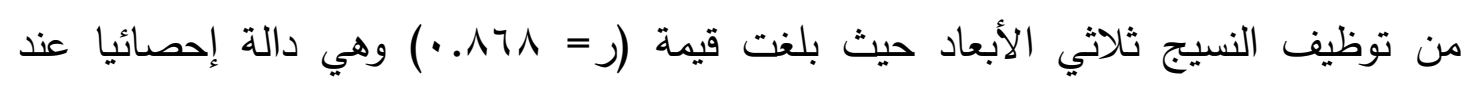
مستوي دلالة (1...)، وهي علاقة طردية قوية أي أن هناك توافق بين التقييم من الناحية العلمية والعملية، حيث وجد أن تصميم رقم (11)، رقم(10) تمثل أفضل التصميمات فى العينة

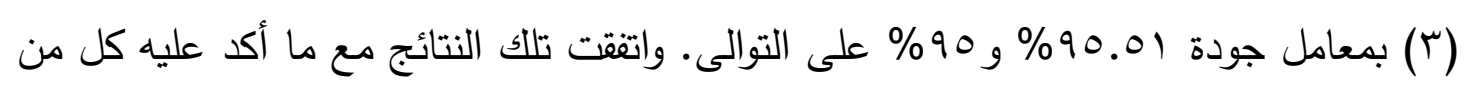
Naveed Ahmed et al,. (2021) \& Nashwa Elshafei (2015)

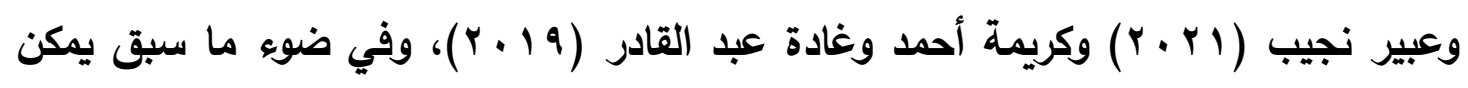
قبول الفرض الرابع للبحث والذي ينص علي: توجد علاقة إرتباطية دالة إحصائياً بين ترتيب

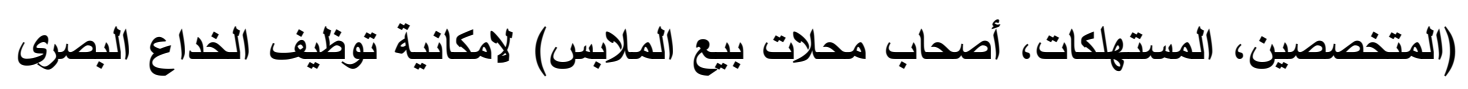
النسجى لإثراء التصميمات المقترحة للأزياء النسائية.

\section{مستخلص النتائج:}

- تنفيذ عدد ثلاث عينات من النسيج اليدوى ثلاثى الأبعاد باستخدام الخامات المختلفة للشرائط،

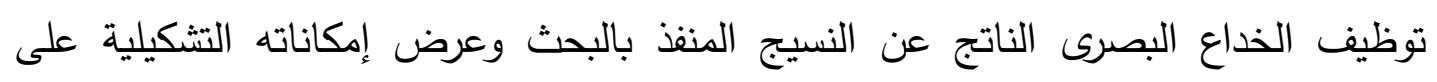
الأزياء المقترحة والحصول على عدد (10) تصميم مقترح لأزياء السيدات الخارجية المعاصرة تتميز بالتثرد والجاذبية بالإضافة إلي إمكانية المساهمة فى إخفاء بعض العيوب العاء الجسمية وتُرتدى فى مناسبات وأوقات مختلفة.

المجلد الثامن- العدد الأول- مسلسل العدد (15)- يناير 2022- الجزء الأول 
- توجد فروق ذات دلالة إحصائية وفقاً لأراء المتخصصين بين امكانية توظيف الخداع البصرى النسجى على التصميمات المقترحة للأزياء النسائية بالبحث فى تحقيق جوانب التقييم (الخداع البصرى، الوظيفى والجمالى والتصميمى، التسويقى والإقتصادى)، وتم التوصل إلي أن أفضل النتائج جاءت لعينة النسيج اليدوى المنفذ رقم (1) "نسيج منتظم بإستخدام الدمج بين شرائط الأورجانزا والستان والتريكو" ونجاح توظيفها على كل من تصميم الجاكيت البليزر رقم (1)

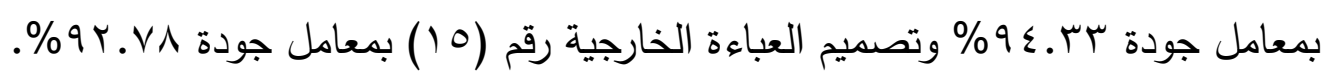
- توجد فروق ذات دلالة إحصائية وفقاً لأراء المستهكات بين امكانية توظيف الخداع البصرى النسجى على التصميمات المقترحة للأزياء النسائية بالبحث فى تحقيق بنود التقييم، وتم التوصل إلي أن أفضل النتائج جاءت لعينة النسيج اليدوى المنفذ رقم (1) "نسيج منتظم بإستخدام الدمج بين شرائط الأورجانزا والستان والتريكو" ونجاح توظيفها على كل من تصميم الجاكيت البليزر رقم (1) (1) بمعامل جودة 9 9.1\% وتصميم العباءة الخارجية رقم (10) بمعامل جودة 97.07\%

- توجد فروق ذات دلالة إحصائية وفقاً لأراء أصحاب محلات بيع الملابس بين امكانية توظيف الخداع البصرى النسجى على التصميمات المقترحة للأزياء النسائية فى تحقيق بنود التقييم، وتم التوصل إلي أن أفضل النتائج جاءت لعينة النسيج اليدوى المنفذ رقم (1) "نسيج منتظم بإستخدام الدمج بين شرائط الأورجانزا والستان والتريكو" ونجاح توظيفها على كل من تصميم الجاكيت البليزر رقم (1) بمعامل جودة ب.ـء9\% وتصميم العباءة الخارجية رقم (10)

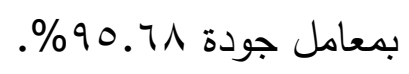
- توجد علاقة إرتباطية دالة إحصائياً بين ترتيب (المتخصصين، المستهلكات، أصحاب محلات بيع الملابس) لامكانية توظيف الخداع البصرى النسجى لإثراء التصميمات المقترحة للأزياء النسائية، وتم التوصل إلي أن أفضل النتائج جاءت لعينة النسيج اليدوى المنفذ رقم (1) "نسيج منتظم بإستخدام الدمج بين شرائط الأورجانزا والستان والتريكو" ونجاح توظيفها على كل من تصميم الجاكيت البليزر رقم (1) بمعامل جودة 90.01\% وتصميم العباءة الخارجية رقم (10) 
- ثبت نجاح توظيف الخداع البصرى النسجى كتقنية عصرية لإثراء التصميمات المقترحة للأزياء النسائية فى ضوء آراء المحكمين مما يساهم فى إتاحة مصدر تقنى وتطبيقى جديد لإثراء الملابس الخارجية للنساء وإبراز جمالياتها. - ثبت نجاح توظيف الخداع البصرى النسجى كتقنية عصرية فى إخفاء بعضش العيوب الجسمية للمرأة بالإضافة إلي أكساب الملابس أناقة وجاذبية وتفرد عن المتاح فى الاسواق المختلفة. - إثراء الأزياء المقترحة واضافة بعد اقتصادى لملائمة التكلفة للمستهلك وقدرتها على المنافسة مع المنتجات المتاحة بالأسواق المختلفة.

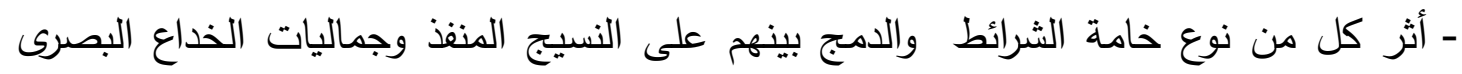
المنتج وبالتالى أثر على تتوع التأثيرات للامكانات التشكيلية على التصميمات المقترحة للأزياء النسائية وأثرتها وأضافت قيم جمالية ووظيفية واقتصادية لها.

\section{المقترحات والبحوث مستقبلية:}

- إبراز قيمة وأهية التصميمات النسجية المبتكرة وتوظيفها فى مجال الأزياء والملابس المختلفة. - الإهتمام بالدراسات المتعلقة بالدمج بين مجالى النسيج والأزياء باستخدام أساليب وتتنيات وخامات جديدة للوصول للنتج مبتكر يفى بإحتياجات المستهلك و ويحقق القيمة الجمالية والتسويقية والتتافسية للمنتج المصرى. - الاهتمام بتمية المشروعات الصغيرة التى تقوم على فكرة العمل اليدوى وإنتاج تصميمات

$$
\text { نسجية وتوظيفها فى مجالات المنسوجات والأزياء. }
$$

- إجراء المزيد من الدراسات التجريبية بتنفيذ منسوجات مستحدثة بخامات مختلفة لإجرء متغيرات جديدة تثري المجال فنياً وجمالياً. - تطوير مقررات النسيج بالتوجه نحو استخدام التقنيات والأساليب التقنية المعاصرة.

\section{المراجع العربية والأحنبية:}

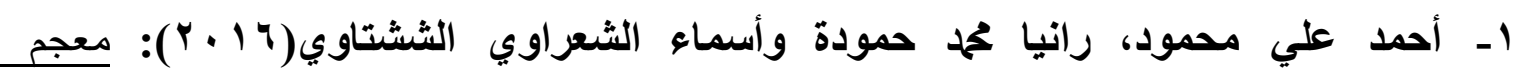
المنسوجات الثقافية، مكتبة نانسي دمياط.

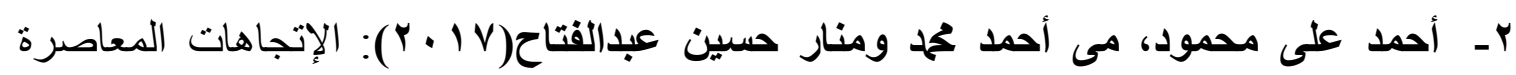

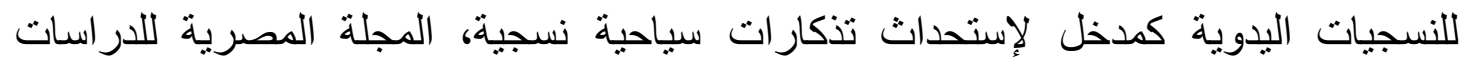
المتخصصة، كلية التربية النوعية، جامعة عين شمس. لإندارت

المجلد الثامن- العدد الأول- مسلسل العدد (15)- يناير 2022- الجزء الأول 


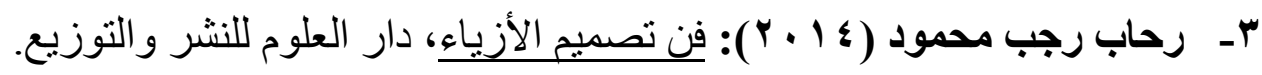

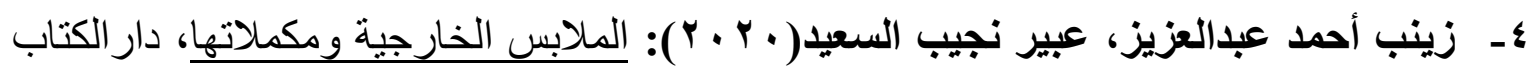
الحديثة، القاهرة. هـ زينب عبدالحافظ على، أسماء على أحمد(ع 1 ب): إستحداث تصميمات مستوحاه من الخداع البصرى مقترحة لمعالجة العيوب الجسمية تصلح للفتاه الجامعية، المؤتمر السنوى،كلية التربية النوعية، جامعة المنصورة.

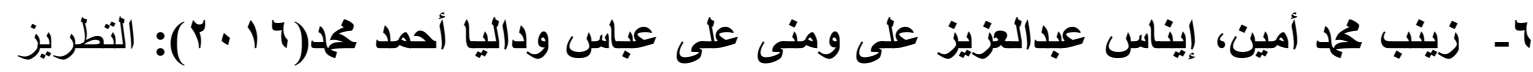
بالثر ائط فى تنفيذ تصميمات عصور تاريخية "تجربة ذاتية"، مجلة البحوث فى التربية النوعية، وعية ودئ كلية التربية النوعية، جامعة المنيا.

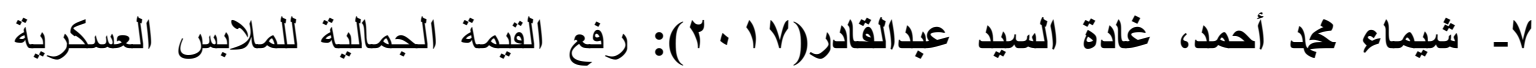

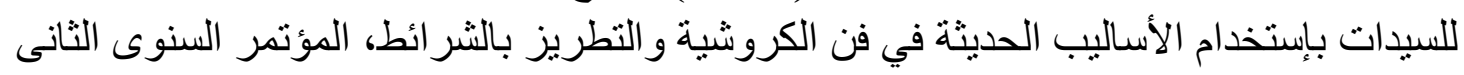

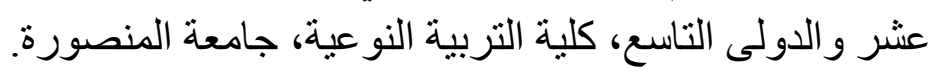

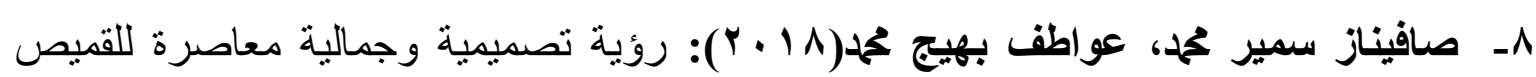

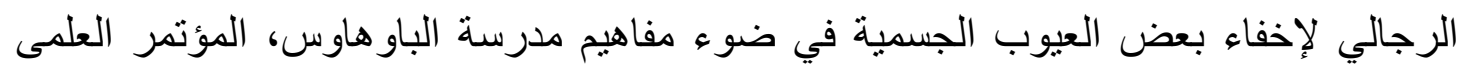

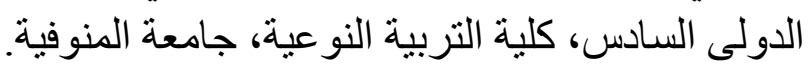

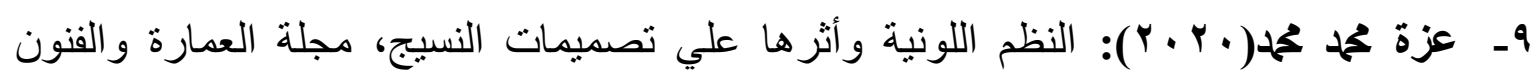

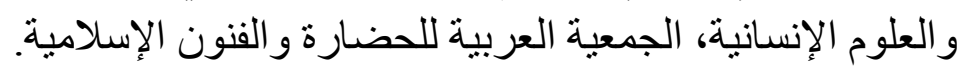
ـ 1 ـ عنايات يوسف رفلة( 9 V 1) ) فن الخداع البصرى، مؤسسة دار التعاون للطبع و النشر، القاهرة.

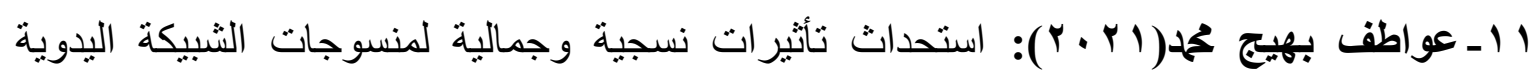
بإستخدام بعض التر اكيب البنائية لثرائط التريكو، مجلة دراسات وبحوث التربية النوعية، كلية

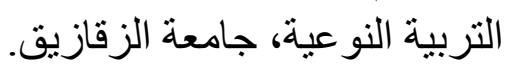

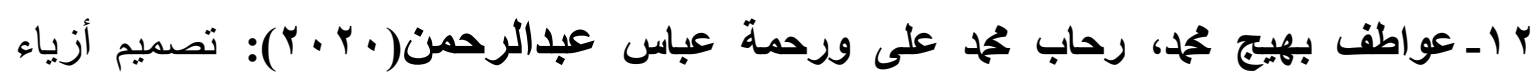

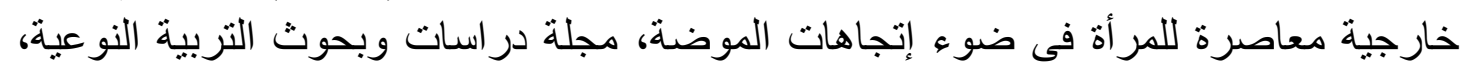

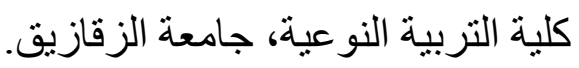

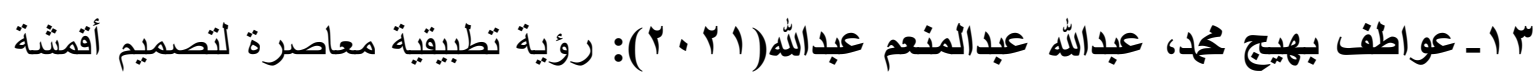
المفروشات فى ضوء الإتجاهات الحديثة للنسيج "البعد السابع"( D D)، مجلة البحوث في مجالات التربية النوعية، كلية التربية النوعية، جامعة المنيا.

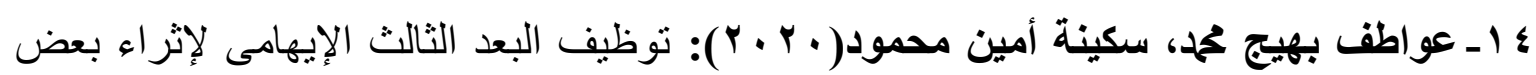

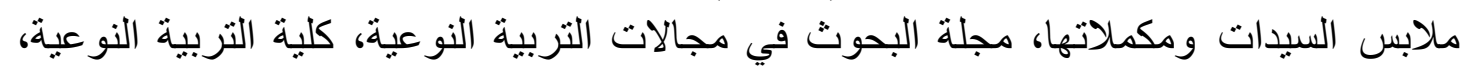
جامعة المنيا.

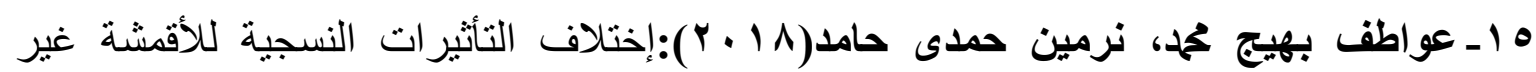
التقليدية وتأثثر ها على جماليات تشكيل ملابس السيدات، المؤتمر العربى الثالث عشر و الدولى الثى

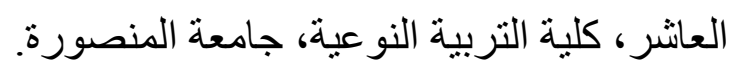




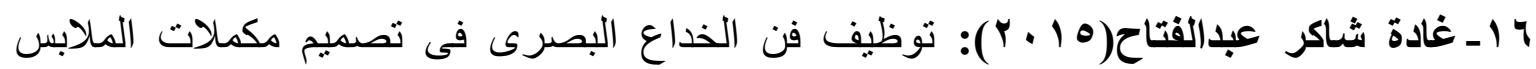
لإخفاء بعض عيوب الجسم، مجلة العلوم والفنون التطبيقية، كلية الفنون التطبيقية.

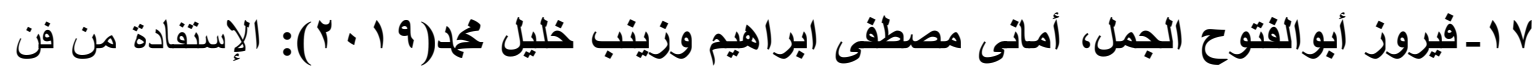

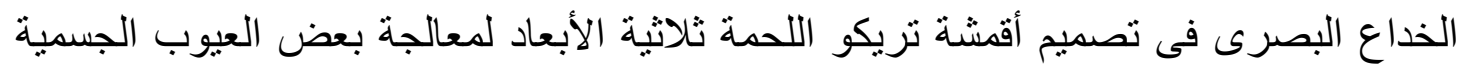
للسيدات"، مجلة التصميم الدولية، جامعة حلو ان. لأن.

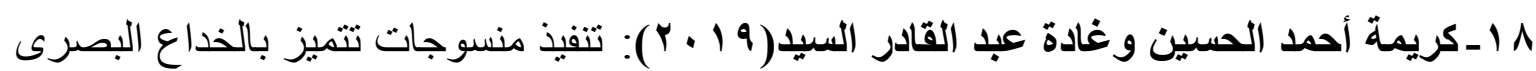
و الإستفادة منها فى اثر اء القيمة الجمالية لحقائب السيدات، المؤتمر العلمي الدولي السابع، كلية التربية النو عية، جامعة المنوفية.

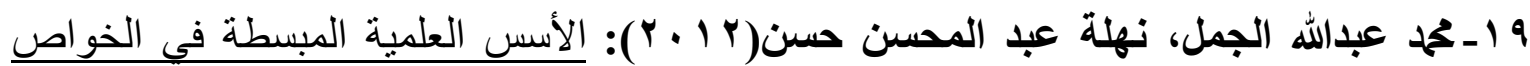

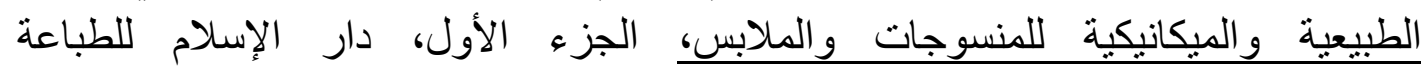

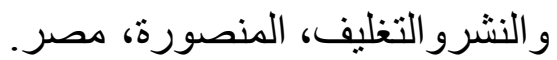

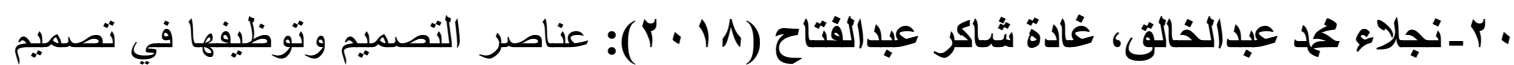
ملابس منزلية لعلاج عيوب الجسم، مجلة التصميم الدولية، الجمعية العلمية للمتخصصين، كلية

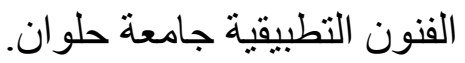

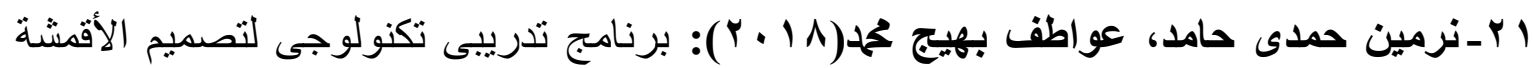

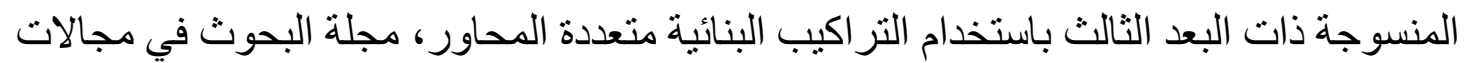
التربية النو عية، كلية التربية النوعية، جامعة المنيا.

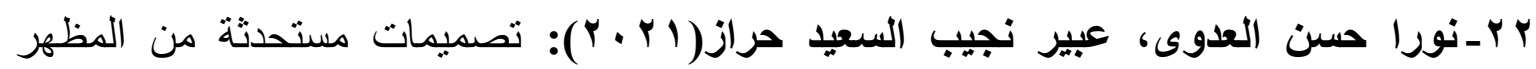

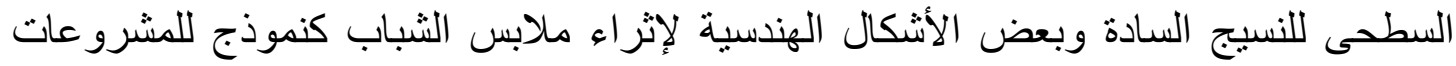
الصغيرة، مجلة التصميم الدولية، كلية الفنون التطبيقية، جامعة حلوان.

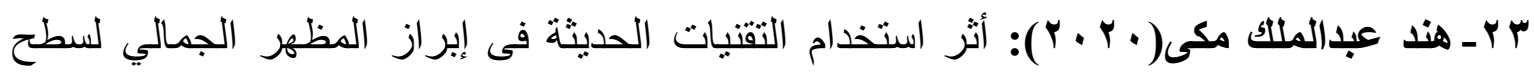
وملمس القماش أسلوب التشكيل علي المانيكان، مجلة التصميم الدولية، كلية الفنون التطبيقية، جامعة حلو ان.

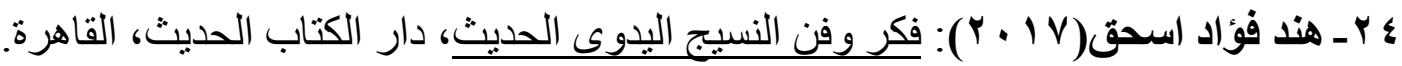

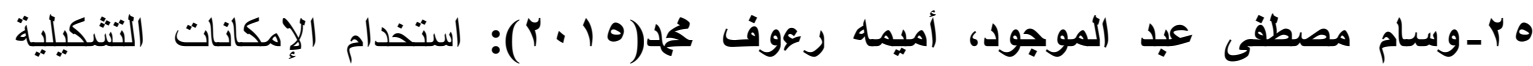
للتر اكيب النسجية لرفع الجانب الجمالي والوظيفي لملابس الطفل بمرحلة الطفولة المتأخرة، مجلة الإسكندرية للبحوث الزر اعية، كلية الزر اعة، جامعة الإسكندرية.

26- Bilisik, K (2016): Two،dimensional (2D) fabrics and three،dimensional (3D) preforms for ballistic and stabbing protection: a review, Text Res J; 87(18), 2275, 2304.

27- Grosicki Z J (2014): Watson's Advanced Textile Design: Compound Woven Structures Woodhead publishing limited,Cambridge,England.

28- Jesse Prinz (2007): "Emotion and Aesthetic Value". An franciscc. 
29- Karaduman N K (2013):three-dimensional fully interlaced woven preforms for composites, Textile journal, Vol.83, No.19.Bilisik.

30- Nashwa Elshafei (2015): The Phenomena of Optical Illusions and Its Impact on Fashion Design Trend, Journal of Basic and Applied, Scientific Research J. Basic. Appl. Sci. Res., 5(7)5-16.

31- Naveed Ahmed Khana, Alessio Ishizakab \& Andrea Genovese (2021): Framework for Evaluating the Supply Chain Performance of Apparel Manufacturing Organizations, May, Volume8, Issue 2, pp. 134164.

32- Zhenzhen Quan, Tsu Wei Chou (2019): Additive Manufacturing of Multidirectional Preforms and Composites, Microstructural Design, Fabrication, and Characterization, Handbook of Mechanics of Materials pp 2353،2406. 